JosÉ ANTONIO SANCHES JUNIOR

\title{
Avaliação morfológica e imunofenotípica de linfócitos no sangue periférico de doentes com eritrodermia: pesquisa de perfil indicativo para o diagnóstico de micose fungóide
}

Tese apresentada à Faculdade de Medicina da Universidade de São Paulo para obtenção do título de Professor Livre-Docente junto ao

Departamento de Dermatologia

\section{São Paulo}

2006 


\section{Dados Internacionais de Catalogação na Publicação (CIP)}

Preparada pela Biblioteca da

Faculdade de Medicina da Universidade de São Paulo

Creprodução autorizada pelo autor

Sanches Junior, José Antonio

Avaliação morfológica e imunofenotípica de linfócitos no sangue periférico de doentes com eritrodermia : pesquisa de perfil indicativo para o diagnóstico de micose fungóide / José Antonio Sanches Junior. -- São Paulo, 2006.

Tese(livre-docência)--Faculdade de Medicina da Universidade de São Paulo. Departamento de Dermatologia. Disciplina de Dermatologia.

Descritores: 1.Dermatite esfoliativa/sangue 2.Micose fungóide/sangue 3.Micose fungóide/diagnóstico 4.Contagem de linfócitos 5.Citometria de fluxo 6.Linfócitos T CD4-Positivos 7.Relação CD4-CD8

USP/FM/SBD-310/06 
Para:

Silvia, Maria Julia, Maria Isabel e João Paulo 


\section{AGRADECIMENTOS}

Ao Professor Evandro Rivitti, exemplo de entusiasmo pela carreira acadêmica e instituição universitária, pela amizade fraterna e oportunidade de aprendizado, não apenas técnico mas sobretudo humano.

Aos Professores Mírian Nacagami Sotto, José Eduardo Costa Martins e Zilda Najjar Prado de Oliveira, pela amizade, ensinamentos e estímulo para a conclusão de mais esta etapa de minha carreira acadêmica.

Aos queridos amigos Celina Wakisaka Maruta, Claudia Giugli Santi, Cyro Festa Neto e Valéria Aoki, pela ajuda incondicional. 
A todos os colegas médicos, amigos e funcionários do Departamento Divisão de Dermatologia, pela possibilidade de convívio "pleno de experiências enriquecedoras".

Aos funcionários do Arquivo Médico do Instituto Central do Hospital das Clínicas da FMUSP, pela gentileza e presteza na busca dos prontuários médicos solicitados.

Às bibliotecárias do Serviço de Biblioteca e Documentação da Faculdade de Medicina da Universidade de São Paulo, pela inestimável orientação e auxílio.

À Divisão de Laboratórios do HCFMUSP - aos Doutores Marcos Antonio Gonçalves Munhoz, Patrícia Aparecida Ferreira de Oliveira, Maria Mirtes Sales, à Professora Leila Antonângelo, e aos funcionários - pela inestimável colaboração às minhas solicitações.

À Doutora Clarisse Sano, que colaborou com a coleta de dados deste estudo em seus tempos de iniciação científica como acadêmica desta Faculdade de Medicina.

Aos pacientes que possibilitaram este trabalho, com o desejo de que possam ser auxiliados, com os resultados ora obtidos, no alívio de suas dores. 
Esta tese está de acordo com:

Referências: adaptado de International Committee of Medical Journals Editor (Vancouver)

Universidade de São Paulo. Faculdade de Medicina. Serviço de Biblioteca e Documentação. Guia de apresentação de dissertações, teses e monografias. Elaborado por Anneliese Carneiro da Cunha, Maria Julia de A. L. Freddi, Maria F. Crestana, Marinalva de Souza Aragão, Suely Campos Cardoso, Valéria Vilhena. São Paulo: Serviço de Biblioteca e Documentação; 2004.

Abreviaturas dos títulos dos periódicos de acordo com List of Journals Indexed in Index Medicus. 


\section{Resumo}

\section{Summary}

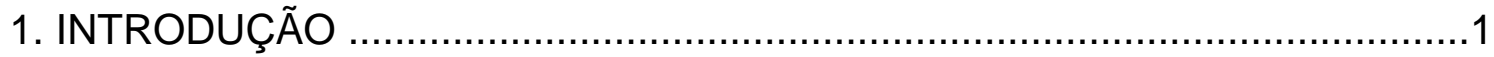

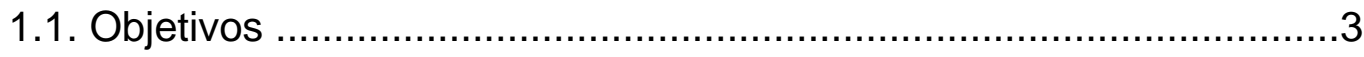

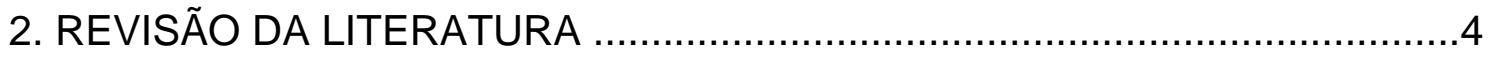

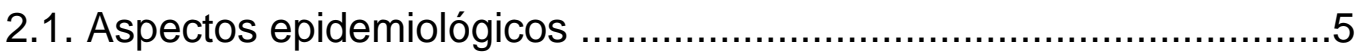

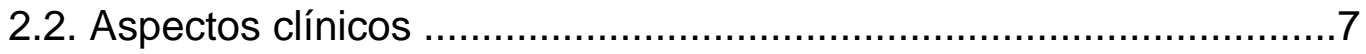

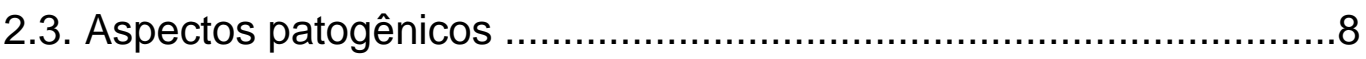

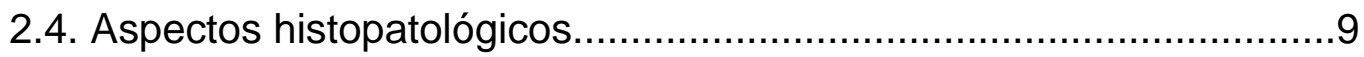

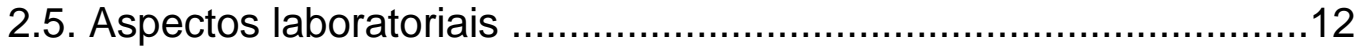

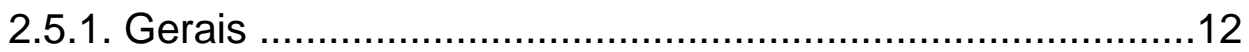

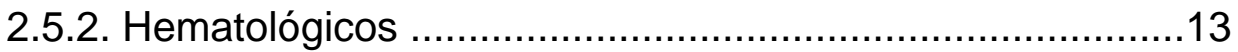

2.5.3. Morfologia dos linfócitos no sangue periférico ................13 
2.5.4. Imunofenótipo dos linfócitos no sangue periférico

2.5.5. Alterações moleculares .................................................18

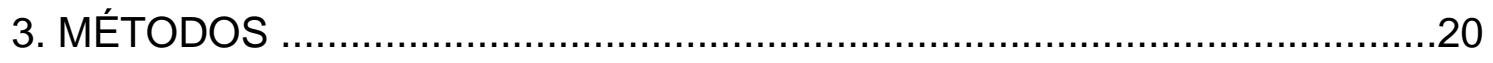

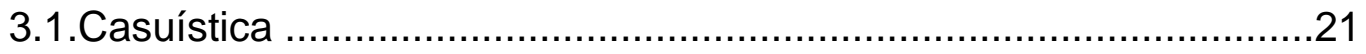

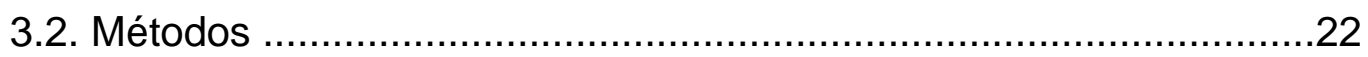

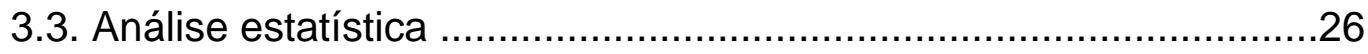

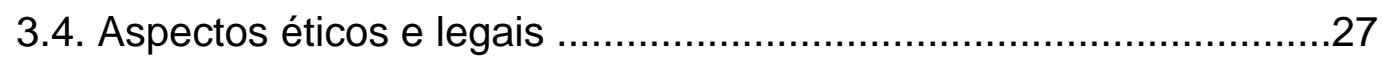

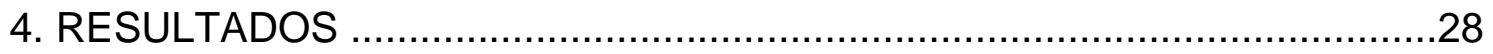

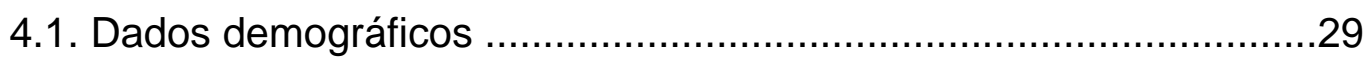

4.2. Dados do hemograma e morfologia dos linfócitos ..........................31

4.2.1. Avaliação dos leucócitos, linfócitos e eosinófilos ...............31

4.2.2. Avaliação morfológica dos linfócitos .................................33

4.3. Dados quantitativos da imunofenotipagem dos linfócitos T..............35

4.3.1. Marcadores de linfócitos T periféricos................................35

4.3.2. Marcadores de linfócitos T CD4 e relação CD4:CD8..........39

4.3.3. Linfócitos CD3 expressando CLA e CD25 …....................41

4.4. Dados qualitativos da imunofenotipagem dos linfócitos $T$................43

4.4.1. Perda da expressão de marcadores de linfócitos $T$...........43

4.4.2. Populações linfocitárias de diferentes tamanhos................44

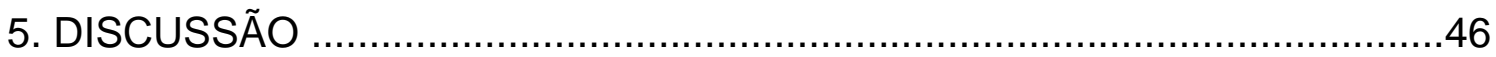

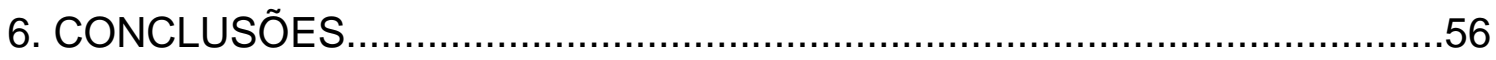

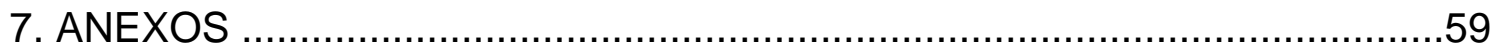

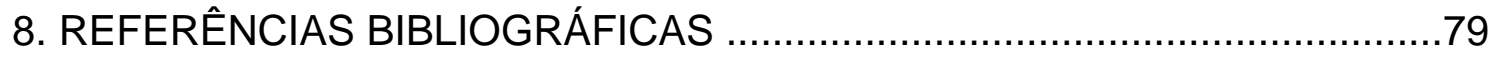


Sanches Junior JA. Avaliação morfológica e imunofenotípica de linfócitos no sangue periférico de doentes com eritrodermia: pesquisa de perfil indicativo para o diagnóstico de micose fungóide [tese]. São Paulo: Faculdade de Medicina, Universidade de São Paulo; 2006. 95p.

INTRODUÇÃO: Eritrodermia é condição cutânea caracterizada por eritema generalizado ocasionado pelo agravamento de dermatoses pré-existentes, por farmacodemias, neoplasias viscerais e por linfomas cutâneos de células $T$ (micose fungóide e síndrome de Sézary). O diagnóstico é realizado pelo exame histopatológico da pele, que entretanto, em muitos casos é inespecífico, não permitindo a conclusão causal para a eritrodermia. MÉTODOS: O presente trabalho avaliou o sangue periférico de 13 doentes com eritrodermias por linfoma cutâneo e 24 com eritrodermias reativas. Analisou-se as alterações quantitativas dos leucócitos, linfócitos e eosinófilos no hemograma, as anomalias linfocitárias classificadas como células de Sézary e linfócitos pleomórficos em esfregaços de sangue periférico e quantificadas em cem leucócitos e, as subpopulações linfocitárias T CD2, CD3, CD4, CD5, CD7, CD8, TCRaß, CLA e CD25 através da avaliação quantitativa e de possíveis anomalias fenotípicas pela técnica de citometria de fluxo. OBJETIVOS: Identificar padrões auxiliares para o diagnóstico de linfoma cutâneo em pacientes com eritrodermias classificadas como idiopáticas. RESULTADOS: Observou-se que o número absoluto de linfócitos $(p<0,018)$, o percentual de células de Sézary $(p<0,014)$, de linfócitos pleomórficos $(p<0,021)$ e de subpopulação de linfócitos $T$ CD3/CD4 $(p<0,049)$, assim como a relação CD4:CD8 $(p<0,015)$, estiveram significantemente aumentados nos pacientes eritrodérmicos com diagnóstico de micose fungóide/síndrome de Sézary em relação aos pacientes com eritrodermias reativas e indivíduos normais e, que aberrações fenotípicas, como perda de marcadores de células T maduras (CD2, CD4, TCRaß) foram observadas exclusivamente na síndrome de Sézary. CONCLUSÕES: A análise quantitativa dos linfócitos no hemograma, a avaliação percentual de células de Sézary e de linfócitos pleomórficos por cem leucócitos em esfregaços de sangue periférico e, a quantificação das subpopulações linfocitárias $T$ CD3/CD4, CD3/CD8 e razão CD4:CD8, através da citometria de fluxo, foram consideradas ferramentas auxiliares contributivas para o diagnóstico de micose fungóide em pacientes eritrodérmicos. A observação de fenótipos anômalos das subpopulações linfocitárias T maduras estiveram presentes apenas nos pacientes com diagnóstico de síndrome de Sézary.

DESCRITORES: Dematite esfoliativa/sangue, micose fungóide/sangue, micose fungóide/diagnóstico, contagem de linfócitos, citometria de fluxo, linfócitos $T$ CD4-positivos, relação CD4-CD8 
Sanches Junior JA. Morphologic and immunophenotypic study of peripheral blood lymphocytes in erythrodermic patients: searching for a contributory profile to the diagnosis of mycosis fungoides [thesis]. São Paulo: "Faculdade de Medicina, Universidade de São Paulo"; 2006. 95p.

INTRODUCTION: Erythroderma is a generalized erythema of the skin caused by the worsening of pre-existing dermatoses, by drug-eruptions, visceral cancers and cutaneous T-cell lymphomas (mycosis fungoides and Sezary syndrome). The diagnosis of these conditions is usually done by histopathological examination of the diseased skin, although it is not always conclusive, with many cases remaining without a correct diagnosis for many years. METHODS: Peripheral blood from 13 patients with erythrodermic cutaneous lymphoma and from 24 patients with reactive erythroderma was analyzed. The study searched for quantitative alterations in total lymphocytes, pleomorphic lymphocytes and Sézary cells in the hemogram and peripheral blood smears and for quantitative changes in CD2, CD4, CD5, CD7, CD8, TCRa $\beta, C L A$ and CD25 subsets of T-cells, as well as for phenotypically abnormal $T$ cells, by flow cytometry. The aim of this study was to identify a simple auxiliary profile to diagnose cutaneous lymphoma in patients with erytroderma classified as idiopathic. RESULTS: The comparison of the mean and median values of the studied parameters between patients with erythrodermic cutaneous lymphoma and the reactive ones revealed expanded counts of absolute lymphocytes $(p<0,018)$, pleomorphyc lymphocytes $(p<0,021)$, Sezary cells $(p<0,014)$ and the CD4 T-cell subset $(p<0,049)$ with increased CD4:CD8 ratio $(p<0,015)$ in the former. Phenotypically abnormal CD2, CD4 and TCRaß $T$ cells were found only in patients with Sezary syndrome. CONCLUSIONS: By these observations it seems that a detailed examination of the hemogram, the leukocyte smear and a quantitative analysis of lymphocyte subsets by flow cytometry might prove usefull to discriminate between benign and lymphomatous erythroderma. Aberrant phenotypes in the mature T-cell could be observed only in Sezary syndrome patients.

KEYWORDS: Exfoliative dermatitis/blood, mycosis fungoides/blood, mycosis fungoides/diagnosis, lymphocyte count, flow cytometry, CD4 positive Tlymphocytes, CD4-CD8 ratio 


\section{INTRODUÇÃO}


Eritrodermia é síndrome caracterizada por eritema generalizado que acomete cerca de 90\% da superfície corpórea, herdado ou desencadeado por dermatoses adquiridas, podendo, até mesmo, ser manifestação cutânea de doença sistêmica (Wilson, 1954).

Dentre as doenças dermatológicas que podem manifestar-se com esta alteração, incluem-se a psoríase, a dermatite seborréica, a pitiríase rubra pilar, o pênfigo foliáceo, a dermatite atópica, os eczemas, as farmacodermias e os linfomas cutâneos de células T (micose fungóide e síndrome de Sézary). O diagnóstico dessas enfermidades é corroborado principalmente por suas características histológicas próprias, porém número considerável de casos apresenta alterações histológicas inespecíficas, de difícil conclusão diagnóstica (eritrodermias idiopáticas). Evolutivamente, verifica-se que muitos desses casos 
idiopáticos desenvolvem linfomas cutâneos diagnosticados apenas em fases avançadas, quando apresentam comprometimento hematológico evidente. Parcela significativa dos pacientes eritrodérmicos requer internações prolongadas devido ao comprometimento do estado geral e à dificuldade na elucidação da causa da eritrodermia (Rym et al., 2005).

Este estudo aborda as eritrodermias adquiridas conseqüentes ao agravamento de dermatoses pré-existentes, à erupções medicamentosas, à neoplasias internas e doenças linfoproliferativas cutâneas. Além de possibilitar acréscimo ao conhecimento da síndrome em questão, poderá contribuir na otimização da abordagem clínico-laboratorial dos pacientes eritrodérmicos.

\subsection{OBJETIVOS}

Este trabalho tem como objetivo avaliar o potencial discriminatório do hemograma e da citometria de fluxo dos linfócitos T no sangue periférico entre doentes com eritrodermias reativas (psoríases, dermatites eczematosas, farmacodermias e outras) e eritrodermias por linfomas cutâneos de células T (micose fungóide e síndrome de Sézary), através da análise de variações numéricas de leucócitos, eosinófilos, linfócitos totais, linfócitos pleomórficos, células de Sézary e alterações imunofenotípicas linfocitárias, quantitativas e qualitativas. 
2. REVISÃO DA LITERATURA 


\subsection{ASPECTOS EPIDEMIOLÓGICOS}

Eritrodemia é síndrome cutânea que se caracteriza por eritema generalizado, com curso subagudo a crônico, habitualmente com descamação, acometendo mais de $90 \%$ da superfície cutânea (Montgomery, 1933; Wilson, 1954). Freqüentemente apresenta-se com prurido de intensidade variável, sendo mais intenso nos indivíduos mais idosos. Sua incidência está estimada entre 0,9 a 2 casos por 100.000 habitantes por ano (Hasan e Jansen, 1983; Sigurdsson et al., 2001) com freqüência em torno de 3 casos para 10.000 consultas dermatológicas (Sehgal e Srivastava, 1986; Rym et al., 2005).

Acomete mais comumente indivíduos acima de 45 anos (Seghal et al., 2004), com médias, descritas na literatura, compreendidas entre 41 e 61 anos. 
Pode, entretanto, ocorrer em crianças e adultos jovens. Predomina no sexo masculino com taxas entre 2 a 4:1. Poucos trabalhos estratificam os casos de acordo com a raça, descrevendo-se predomínio em brancos nos EUA e em negros na África do Sul. (Gentele et al., 1958; Abrahams et al., 1963; Nicolis e Helwig, 1973; Hasan e Jansen, 1983; King et al., 1986; Thestrup-Pedersen et al., 1988; Botella-Estrada et al., 1994; Vasconcellos et al., 1995; Sigurdsson et al., 1996; Sigurdsson et al., 1997; Pal e Haroon, 1998; Leenutaphong et al., 1999; Morar et al., 1999; Rothe et al., 2000; Akhyani et al., 2005).

Relaciona-se mais freqüentemente com dermatoses pré-existentes (25 $62,5 \%)$, com o uso de medicamentos, tópicos ou sistêmicos, (5 - 42\%) e com linfomas cutâneos de células T (LCCT) (13 - 40\%). Pode, ainda, associar-se com neoplasias internas $(1-2,8 \%)$ ou outras doenças $(0,7-1 \%)$ e não raramente, a despeito de todos os esforços diagnósticos, uma proporção significativa de pacientes permanece sem definição da etiologia, classificandose como portadores de eritrodermias idiopáticas (7,2 - 47\%) (Abrahams et al., 1963; Nicolis e Helwig, 1973; Hasan e Jansen, 1983; King et al., 1986; Sehgal e Srivastava, 1986; Botella-Estrada et al., 1994; Vasconcellos et al., 1995; Sigurdsson et al., 1996; Pal e Haroon, 1998; Karakayli et al., 1999; Akhyani et al, 2005; Rym et al., 2005). 


\subsection{ASPECTOS CLÍNICOS}

A eritrodermia inicia-se com áreas de eritema pruriginoso que coalescem generalizando-se até acometer praticamente toda superfície cutânea. As formas que se desenvolvem mais agudamente acompanham-se de escamas maiores e àquelas mais crônicas, de descamação mais fina. Um início agudo e rápido pode ser observado em pacientes com hipersensibilidade à drogas e pitiríase rubra pilar (PRP). Reações por drogas tendem a regredir mais rapidamente que outras formas de eritrodermia. Pacientes com eritrodermia por psoríase ou eczemas freqüentemente têm histórias prévias da presença de lesões cutâneas. Prurido intenso associa-se, comumente, com síndrome de Sézary, dermatite atópica e eczema de contato alérgico. (Sigurdsson et al., 1996; Pal e Haroon, 1998; Rym et al., 2005)

Clinicamente, a pele apresenta-se com eritema de tonalidade róseosalmão a vinhosa, quente e, habitualmente, endurada ou edematosa. A eritrodermia pode poupar o centro da face (sinal do nariz) (15\%), poupar dobras cutâneas (sinal da cadeira de praia) (5\%) ou apresentar ilhotas de pele sã (15\%). Acentuação dos óstios foliculares, com rolhas córneas ou material mucinoso, pode ser observado. Os casos de longa duração, habitualmente, apresentam-se com liquenificação e hiperpigmentação generalizadas (35 $45 \%$ ) e aqueles com prurido intenso, com escoriações. Queratodermia palmoplantar, em áreas ou difusa, pode ser observada (40\%), sendo fissuradas e dolorosas nos casos crônicos de síndrome de Sézary (SS). Pacientes negros 
podem desenvolver discromias vitiligóides. Na ocorrência de inflamação periorbital importante de longa duração, desenvolve-se ectrópio e epífora $(17,2 \%)$. Edema dos pés, tornozelos e membros inferiores (20\%) podem estar presentes, e edema da face relaciona-se com reação por drogas, habitualmente desencadeadas por anticonvulsivantes. Rarefação difusa dos pêlos e cabelos é achado freqüente nos casos mais crônicos (30\%), assim como onicodistrofias (50 - 80\%). Alterações das lâminas ungueais com depressões cupuliformes, áreas eritemato-amareladas que se assemelham à manchas causadas por óleo em papel e sulcos de Beau podem sugerir psoríase e, unhas brilhantes e curtas podem acompanhar casos com prurido muito intenso. Linfonodomegalias estão presentes em cerca de 25\% dos casos (Pavithran, 1988; Agarwal et al., 1992; Rothe et al., 2000; Sehgal et al., 2004; Akhyani et al., 2005; Rym et al., 2005).

\subsection{ASPECTOS PATOGÊNICOS}

A patogênese da eritrodermia não está esclarecida. Acredita-se que a condição seja secundária a interação de citocinas, IL-1, IL-2, IL-8 e TNF e moléculas de adesão, como ICAM-1 (Groves et al., 1995). Esta interação resultaria em vasodilatação e em aumento do "turnover" epidérmico causando uma elevação na taxa mitótica normal e no número absoluto de células germinativas da camada basal com diminuição do tempo de maturação e da migração celular. Estas alterações manifestam-se com incremento da 
eliminação de material epidérmico, com significante perda de proteínas e folato (Rothe et al., 2000; Sehgal et al., 2004).

O aumento do aporte sanguíneo para a pele, nos pacientes eritrodérmicos, resulta em perda de calor com distúrbios na termorregulação, levando à hipotermia ou hipertermia, além de poder resultar em insuficiência cardíaca de alto débito. Entretanto, é mais freqüente que estes pacientes apresentem-se febris por hipermetabolismo compensatório e aumento da taxa metabólica basal, sem alteração da atividade tireoideana. Os tremores e a febre poderiam também ser explicados por bacteremias a partir de contaminação da pele inflamada. Observa-se perda protéica excessiva por descamação e exudação, e hemodiluição devida ao aumento do volume plasmático, com hipoalbuminemia e edema importantes. O comprometimento da integridade cutânea pode desencadear bacteremias aumentando a susceptibilidade para diversos processos infecciosos e mesmo septicemias. Trata-se, portanto, de quadro potencialmente grave com deterioração significativa da qualidade de vida (Rothe et al., 2000; Sehgal et al., 2004).

\subsection{ASPECTOS HISTOPATOLÓGICOS}

As alterações histopatológicas, na pele eritrodérmica, freqüentemente são inespecíficas observando-se hiperqueratose ortoqueratótica ou paraqueratótica e infiltrado perivascular crônico, com ou sem eosinofilia. Os achados específicos das dermatoses que podem culminar com eritrodermia 
estão freqüentemente mascarados pelas alterações inespecíficas (BotellaEstrada et al., 1994), entretanto o estágio da eritrodermia pode influenciar no aspecto histológico. Nos casos mais agudos, paraqueratose e espongiose são mais proeminentes, enquanto nos estágios mais crônicos observa-se acantose com alongamento dos cones epiteliais. Estudos, entretanto, têm demonstrado que, a despeito da uniformidade do quadro cutâneo e da inespeficidade do exame histopatológico, a observação cuidadosa de múltiplas biopsias realizadas em uma mesma ocasião e em diferentes períodos podem incrementar seu poder diagnóstico (Walsh et al., 1994), pois os achados histopatológicos diagnósticos da doença subjacente estariam retidos na maioria dos casos (Zipp et al., 1993). Além disto, biopsias de áreas mais características poderiam confirmar o diagnóstico de psoríase em cerca de 60 a $88 \%$ dos casos e de PRP em 25\% dos casos (Walsh et al., 1994; Tomasini et al., 1997; Levine, 2000). A acurácia diagnóstica nos quadros eczematosos, com evidência de dermatite espongiótica, pode chegar a cerca de 65\% (Walsh et al., 1994). Dermatites esfoliativas induzidas por drogas freqüentemente revelam dermatite liquenóide de interface de difícil diagnóstico diferencial com o epidermotropismo característico do linfomas cutâneos de células T (Sentis et al., 1986; Patterson et al., 1991; Walsh et al., 1994). O diagnóstico histopatológico dos linfomas cutâneos epidermotrópicos de células $T$, micose fungóide e síndrome de Sézary, baseiam-se na observação de pelo menos um de três critérios descritos a seguir: -epidermotropismo de linfócitos atípicos, com núcleos convolutos de aspecto cerebriforme, maiores que os linfócitos presentes na derme; -presença 
de grandes linfócitos hipercromáticos, com halos claros, enfileirados nas camadas basal e parabasal da epiderme e folículo piloso; -presença de agrupamento de ao menos três linfócitos na epiderme (microabcesso de Pautrier) (Willenze et al., 2005). O estudo imunoistoquímico pode, também, contribuir na distinção entre linfomas cutâneos e condições benignas da pele: na micose fungóide pode haver perda do antígeno pan-T CD7 nas células $\mathrm{CD}^{+} \mathrm{CD}^{+}$do infiltrado tumoral mas não nos infiltrados benignos (Wood et al., 1990). Entretanto, na micose fungóide eritrodérmica, os aspectos histológicos podem ser ainda mais sutis que aqueles observados nos estágios precoces dos linfomas cutâneos. Pacientes com diagnóstico de síndrome de Sézary, corroborado pela demonstração de envolvimento do sangue periférico por população clonal através de técnicas de biologia molecular, podem apresentar alterações histológicas totalmente inespecíficas (Trotter et al., 1997; Rothe et al., 2000) com ausência de epidermotropismo na maioria dos casos e presença de alterações epidérmicas reativas como espongiose (87\%), paraqueratose (55\%) e acantose (61\%) (Diwan et al., 2005). O infiltrado polimorfo e inespecífico inicial podem, entretanto, ir adquirindo, com o tempo, aspectos diagnósticos específicos. Estes fatos confirmam a necessidade de realização de repetidas biopsias sucessivas, juntamente com a investigação dos linfócitos no sangue periférico, e seguimento clínico adequado para a realização do diagnóstico correto acerca da etiologia da eritrodermia (Walsh et al., 1994; Rothe et al., 2000). 


\subsection{ASPECTOS LABORATORIAIS}

\subsubsection{GERAIS}

Relata-se o encontro de anemia discreta, de elevação da velocidade de hemossedimentação (VHS), hiperuricemia, hipoalbuminemia e hiperglobulinemia. Elevação dos valores de $\lg E$ tem sido associada com dermatite atópica, com erupções por drogas, com quadros graves de psoríase, e também com síndrome de Sézary (Kim et al., 1995; Li et al., 2005). Elevação dos níveis séricos de lactato deidrogenase $(\mathrm{DHL})$ é relatado em $85 \%$ dos casos de erupções medicamentosas por anticonvulsivantes (Callot et al., 1996) e nos pacientes com síndrome de Sézary (Kim et al., 1995). Enzimas hepatocelulares apresentam-se alteradas em cerca de $74 \%$ dos casos de farmacodermias por anticonvulsivantes (Callot et al., 1996) mas raramente em outras eritrodermias.

Embora aumento do volume dos linfonodos seja evidente na maioria dos pacientes eritrodérmicos, o exame histopatológico dessas estruturas, freqüentemente, revela apenas linfadenite dermatopática. Mesmo nos quadros eritrodérmicos por linfomas cutâneos, raramente observa-se comprometimento linfonodal francamente neoplásico (lyer et al., 1998).

A despeito de, com certa freqüência, haver circulação de células de

Sézary no sangue periférico nos casos de linfomas cutâneos de células $T$, a medula óssea está habitualmente poupada, com exceção das fases muito 
avançadas da doença em indivíduos com altos percentuais de células anômalas circulantes (Edelson et al., 1974).

\subsubsection{HEMATOLÓGICOS}

Leucocitose, linfocitose e eosinofilia com presença de linfócitos atípicos são achados freqüentes nos casos de erupções por medicamentos anticonvulsivantes (Callot et al., 1996), mas relatados apenas nos casos mais avançados de LCCT (Edelson et al., 1974; Kim et al., 1995).

\subsubsection{MORFOLOGIA DOS LINFÓCITOS NO SANGUE} PERIFÉRICO

A definição e o significado do envolvimento do sangue periférico nos linfomas cutâneos de células T ainda não estão completamente elucidadas. Técnicas de análise molecular são capazes de demonstrar células T clonais circulantes, idênticas às presentes nas lesões cutâneas, em todas as fases da doença, inclusive nos estágios muito iniciais (Veelken et al., 1995). Células de Sézary (CS) circulantes têm sido relatadas em cerca de 10\% de pacientes com placas generalizadas, em $25 \%$ de pacientes com tumores cutâneos e na maioria de pacientes com eritrodermia, mas têm sido também descritas em doenças cutâneas inflamatórias (Lutzner et al., 1971; Guccion et al., 1979; Payne et al., 1991), em pacientes com erupções por anticonvulsivantes (Callot 
et al., 1996) e mesmo em indivíduos normais (Meijer et al., 1977; Matutes et al., 1983). Linfócitos normais estimulados através do complexo $\mathrm{CD}^{+}$adquirem formato cerebriforme indistinguíveis de pequenas células de Sézary (Reinhold et al., 1994). A identificação, quantificação e distinção entre linfócitos reativos e neoplásicos através da morfologia nos esfregaços de sangue periférico, por microscopia óptica, não são fáceis. Análises realizadas por diferentes observadores afeitos à técnica podem demonstrar resultados diferentes para um mesmo caso. Linfócitos com pleomorfismo nuclear (LP) ou seja, com alterações nucleares inespecíficas, não típicas de CS, podem ser interpretados erroneamente como CS. Entretanto, a quantificação cuidadosa de linfócitos com núcleos pleomórficos podem ser valorizadas na interpretação dos casos. Quantidade percentuais de CS acima de $7 \%$ e de LP acima de $24 \%$, avaliadas por cem linfócitos em esfregaços de cremes leucocitários, são relatadas apenas em doentes com micose fungóide, mas não em indivíduos normais, sendo mais freqüentes nas fases mais avançadas da doença (Oliveira, 2005). A utilização da microscopia eletrônica, que melhora a acurácia na identificação das células de Sézary, é impraticável na rotina diagnóstica (Lutzner e Jordan, 1968; Flaxman et al., 1971; Winkelman e Hoagland, 1980; Kamarashev et al., 1998; Washington et al., 2002). As CS podem ser agrupadas em três categorias: linfócitos pequenos $(8-11 \mu \mathrm{m})$, de tamanho semelhante ao dos linfócitos normais não ativados, porém com núcleos convolutos; - linfócitos grandes ( $\geq 12$ $\mu m)$ com núcleos convolutos, hipercromáticos, contornados por fina camada de 
citoplasma contendo numerosas vesículas dispostas como um fio e marcadas por PAS; e - células blastóides ( $\geq 14 \mu \mathrm{m}$ ) que possuem núcleo cerebriforme e citoplasma granular abundante com ou sem vesículas e nucléolo proeminente presentes, habitualmente, nos estágios avançados da doença (Miale, 1978; Stolz et al., 1983; Van Fletcher et al., 1984; Vonderheid et al., 2002). A especificidade diagnóstica das contagens de CS pode ser melhorada considerando-se o tamanho das células em adição ao formato nuclear, pois CS $\geq 12 \mu \mathrm{m}$ são mais indicativas de malignidade (Litovitz e Lutzner, 1974) e CS muito grandes (> $14 \mu \mathrm{m}$ ) não são observadas em doenças benignas mas apenas em uma minoria de pacientes com SS (Winkelman e Peters, 1981; Vonderheid et al., 1985; Oliveira, 2005). A quantificação das CS, no sangue periférico, como método auxiliar no diagnóstico da SS ainda é motivo de controvérsia. Valores de CS $\geq 5 \%$ em esfregaço de sangue periférico (Bunn e Lamberg, 1979), CS $\geq 10 \%$ na contagem leucocitária (Winkelman, 1973), CS $\geq$ 15\% nos esfregaços de sangue periférico (Winkelman, 1974; Vonderheid et al., 1985) e CS $\geq 20 \%$ nos esfregaços de sangue periférico (Willenze et al., 1983; Schechter et al., 1987; Sausville et al., 1988) têm sido propostos como pontos ideais de corte. Entretanto, relata-se que valores de CS $\geq 20 \%$ são encontrados em pacientes com eritrodermias reativas, particularmente no reticulóide actínico (Chu et al., 1986) e nos pseudolinfomas induzidos por drogas (Rosenthal et al., 1982; D'Incan et al., 1992). 
A normatização para o acometimento hematológico ("blood" $(B)$ ) nos linfomas cutâneos de células $T$ foi realizada através de consenso da "International Society for Cutaneous Lymphoma" (ISCL) que considera como envolvimento hematológico tipo $B 1$, evidência citológica de: $-\geq 20 \%$ de linfócitos anormais (células de Sézary) nos esfregaços de sangue, ou $-\geq 5 \%$ de linfócitos anormais (células de Sézary) associados à evidência de clone de células $T$ no sangue periférico por PCR ou outra metodologia. Como diagnóstico do envolvimento leucêmico do sangue periférico tipo B2, necessário para a caracterização da síndrome de Sézary, considera: - contagem absoluta mínima de 1000 células de Sézary / $\mathrm{mm}^{3}$; ou - aumento da relação CD4:CD8 $\geq$ 10 decorrente do aumento de células $\mathrm{T} \mathrm{CD}^{+} \mathrm{CD}^{+}$circulantes por citometria de fluxo (CMF); ou - expressão aberrante de marcadores $\mathrm{T}\left(\mathrm{CD} 2^{+}, \mathrm{CD} 3^{+}, \mathrm{CD} 4^{+}\right.$, $\mathrm{CD}^{+}$) por CMF; ou -expressão deficiente de CD7 nas células T (ou expansão de células $\mathrm{CD}^{+} \mathrm{CD}^{-} \geq 40 \%$ ) por CMF (critério ainda provisório); ou - aumento da contagem linfocitária com evidência de um clone de células $T$ no sangue periférico por técnica de "Southern blot" ou PCR ou clone de células T cromossomicamente anormal. Nos casos em que o diagnóstico de LCCT não tenha sido confirmado no exame histopatológico de pele ou de linfonodo são necessárias evidências adicionais de diagnóstico de malignidade, como: - a presença de grandes CS (> $14 \mu \mathrm{m}$ ) em esfregaços de sangue periférico; ou evidência de células T com expressão aberrante de marcadores de células T ou células anormalmente grandes pela CMF; ou - demonstração de clone de 
células T idêntico na pele e no sangue periférico por método de "Southern blot" ou PCR (Vonderheid et al., 2002).

\subsubsection{IMUNOFENÓTIPO DOS LINFÓCITOS NO SANGUE} PERIFÉRICO

A avaliação de características físicas, como o tamanho celular, e de características imunológicas, como a expressão de antígenos na membrana e no interior de células do sangue periférico e de diversos tecidos, através da técnica da citometria de fluxo, permitem estudos de mecanismos etiopatogênicos além de auxiliar no diagnóstico de diversas doenças, principalmente neoplásicas.

Tem-se demonstrado redução de células TCRyঠ circulantes na psoríase (Willenze et al., 1985), presença de linfócitos duplamente marcados $C D 4^{+} C D 8^{+}$ em cerca de $10 \%$ de indivíduos com dermatite atópica (Bang et al., 2001) e aumento da expressão do antígeno linfocitário cutâneo (CLA) e do receptor de IL-2 (CD25) nos linfócitos T circulantes de indivíduos com farmacodermia por anticonvulsivantes (Leyva et al., 2000). Verifica-se que a maioria dos linfócitos anômalos circulantes no sangue periférico, em linfonodos, e outros tecidos, nos linfomas cutâneos de células $T$, é expansão clonal de células $T$ maduras circulantes TCR $\alpha \beta^{+} \mathrm{CD} 2^{+} \mathrm{CD} 3^{+} \mathrm{CD} 4^{+} \mathrm{CD} 5^{+} \mathrm{CD} 8^{-}$. A expressão de $\mathrm{CD} 7$, que ocorre normalmente em cerca de $90 \%$ das células $\mathrm{T} \mathrm{CD}^{+}$é deficiente nas células $\mathrm{T}$ 
malignas circulantes $\left(\mathrm{CD}^{+}{ }^{+} \mathrm{CD} 7^{-}\right)$em aproximadamente $60-70 \%$ dos casos de SS (Jakob et al., 1996; Harmon et al., 1996; Bernengo et al., 1998; Laetsch et al., 2000). Embora a diminuição da expressão de CD7 seja uma característica comum das CS, também define um subtipo de células de memória normais, $\mathrm{CD}^{+} \mathrm{CD}^{2} 5 \mathrm{RO}^{+} \mathrm{CD}^{-}$, que podem estar aumentadas em pacientes com doenças cutâneas benignas ou malignas (Haynes et al., 1981; Labastide et al., 1990). Outra característica das CS está na apresentação do fenótipo $C D 4^{+} C D 26$. Entretanto, até $5 \%$ das células $\mathrm{T}$ normais circulantes também apresentam este fenótipo. Portanto, anomalias de fenótipo, como percentual de células $\mathrm{CD}^{+} \mathrm{CD} 7^{-}>40 \%$, ou de células $\mathrm{CD}^{+} \mathrm{CD}^{-} 6^{-}>30 \%$ ou aumento de células com co-expressão de antígenos $\mathrm{CD} 4^{+} \mathrm{CD} 8^{+}$podem corresponder à presença de linfócitos T neoplásicos no sangue periférico (Bernengo et al., 2001). Verificamse menos freqüentemente, fenótipos aberrantes nos linfócitos circulantes, como perda de marcadores de células $\mathrm{T}$ maduras, CD2, CD3, CD4 ou CD5 (Economidou et al., 1985; Lima et al., 2003) ou diminuição dos níveis de expressão de CD3 ou CD4 (CD3“dim", CD4"dim").

\subsubsection{ALTERAÇÕES MOLECULARES}

A adição da pesquisa de clonalidade dos linfócitos T nas lesões cutâneas e nos linfócitos do sangue periférico, através da análise do rearranjo do gene do receptor de célula T (TCR), por técnica de PCR, aumenta a sensibilidade para o diagnóstico de linfomas cutâneos. Estudos demonstram rearranjo monoclonal 
para o gene do TCR no sangue periférico em cerca de 40 a $80 \%$ dos casos de eritrodermias por LCCT e em $0-5 \%$ de pacientes com eritrodermias reativas (Bakels et al., 1991; Cordel et al., 2005). A detecção isolada de clones dominantes de células $T$ no sangue periférico pode não ser tumoral e relacionar-se com idade avançada. Entretanto, a demonstração de clones dominantes idênticos em lesões cutâneas e no sangue periférico de doentes eritrodérmicos sugere fortemente o diagnóstico de linfoma cutâneo (DelfauLarue et al., 2000). 
3. MÉTODOS 


\subsection{CASUÍSTICA}

Trinta e sete casos consecutivos, com diagnóstico de eritrodermias adquiridas e, submetidos a hemograma, estudo morfológico e imunofenotípico dos linfócitos do sangue periférico, observados na Divisão de Dermatologia do Hospital das Clínicas da Faculdade de Medicina da Universidade de São Paulo, no período compreendido entre agosto de 2001 e abril de 2006, foram avaliados (anexos 1-8). Este grupo resultou de seleção, através da revisão do prontuário médico de cada doente, considerando-se os seguintes critérios de exclusão:

a. Eritrodermias idiopáticas

b. Pacientes com sorologia positiva para HIV e HTLV-1/2 
c. Pacientes com neoplasias hematológicas em fase circulante, com exceção de linfomas cutâneos de células T.

d. Pacientes com imunodeficiências primárias ou adquiridas

e. Pacientes sob terapia sistêmica com corticosteróide em dose acima de 0,5 mg/kg de peso por período acima de 15 dias, em uso de drogas imunossupressoras, antineoplásicas ou modificadoras da resposta biológica na ocasião da coleta do sangue periférico para realização da avaliação morfológica e imunofenotípica dos linfócitos.

Um grupo controle, sem doença cutânea, linfoproliferativa, infecciosa ou imunodeficiência foi constituído por 19 doadores voluntários do Banco de Sangue da Divisão de Hematologia do Hospital das Clínicas da Universidade de São Paulo, por cinco pacientes ambulatoriais e por duas funcionárias da Divisão de Laboratório Central do Hospital das Clínicas da Universidade de São Paulo. Estes sete voluntários não doadores foram selecionados para proporcionar média de idades mais próxima dos grupos com eritrodermias (anexos 9 e 10).

\subsection{MÉTODOS}

Dados demográficos, como idade na ocasião da primeira avaliação dermatológica para o diagnóstico em questão, sexo e cor foram anotados. Definiu-se como tempo de evolução o período compreendido entre o início do quadro eritrodérmico e a data da primeira observação. 
A história de doença dermatológica pregressa e bem definida, o resultado do exame histopatológico da pele lesada, o relato de exposição prévia à drogas e com contemporaneidade em relação ao surgimento do quadro, e achados hematológicos, morfológicos e / ou imunofenotípicos bem estabelecidos para o diagnóstico de envolvimento hematológico por linfoma cutâneo, foram considerados na categorização de dois grupos de doentes:

a. Grupo "Reativo". Foram incluídos neste grupo, seis pacientes com diagnóstico de dermatite atópica, quatro pacientes com dermatites eczematosas de contato, oito pacientes com diagnóstico prévio de psoríase, três pacientes que inquestionavelmente desenvolveram o quadro de eritrodermia após uso endógeno de drogas com resolução do mesmo após suspensão da (s) droga (s) em questão, com ou sem uso de corticoterapia tópica ou sistêmica adjuvante, e, três pacientes que na investigação do quadro eritrodérmico fez-se o diagnóstico de neoplasia interna não hematológica.

b. Grupo "Micose fungóide / síndrome de Sezary" ("MF/SS"). Este grupo ficou composto por 13 pacientes com diagnóstico de linfoma cutâneo de células $T$ confirmado por exame histopatológico e pela evolução clínica. Os pacientes classificados como portadores de síndrome de Sézary preencheram os critérios atualmente propostos pela "International Society for Cutaneous Lymphomas" (Vonderheid et al., 2002). 
Os valores dos glóbulos brancos, linfócitos, eosinófilos, células de Sézary e linfócitos pleomórficos, assim como os valores referentes a imunofenotipagem linfocitária, foram obtidos a partir de exames realizados na Seção de Hematologia da Divisão de Laboratórios do Hospital das Clínicas da Faculdade de Medicina da Universidade de São Paulo.

Os hemogramas foram realizados em aparelho hematológico automatizado. A contagem diferencial de linfócitos "morfologicamente alterados", efetuada em esfregaços de sangue periférico corados pelo método de Leischman (coloração automatizada), em objetiva de imersão com aumento de mil vezes, foi realizada "por cem leucócitos" para os pacientes eritrodérmicos e "por cem linfócitos" para os pacientes controles do grupo normal, não possibilitando, portanto, comparação entre os dois grupos de pacientes eritrodérmicos com o grupo normal. A análise da morfologia dos linfócitos permitiu classificá-los como:

a. linfócitos normais,

b. linfócitos com pleomorfismo nuclear (definidos como linfócitos com alterações morfológicas nucleares inespecíficas), ou

c. células de Sézary pequenas e células de Sézary grandes.

A aquisição e análise dos dados referentes ao número de populações linfocitárias, ao tamanho celular das populações a ao imunofenótipo celular em amostras de sangue periférico dos pacientes foram realizadas em citômetro de fluxo FACSCalibur ${ }^{\mathrm{TM}}$ equipado com lasers de $488 \mathrm{~nm}$ e de $625 \mathrm{~nm}$. Através da 
análise gráfica de tamanho e complexidade interna, selecionou-se e avaliou-se a população linfocitária conforme técnica do programa ("software") CellQuest . O painel de anticorpos monoclonais utilizados incluiu os seguintes marcadores: -antígenos T associados: CD2, CD3, CD4, CD5, CD7, CD8, TCR $\alpha \beta$ e TCR $\gamma \delta$; receptor de interleucina-2: CD25; antígeno linfocitário cutâneo: CLA; antígeno B: CD19; antígenos NK: CD3-/CD16+/CD56+ e, - controles isotípicos.

As variáveis consideradas para o estudo, glóbulos brancos, linfócitos, eosinófilos, células de Sézary, linfócitos pleomórficos, marcadores linfocitários T (CD3, CD2, CD4, CD5, CD7, CD8, TCR $\alpha \beta, T C R y \delta)$, células T CD3 com expressão do antígeno linfocitário cutâneo (CD3/CLA) e células T CD3 com expressão do receptor de IL-2 (CD3/CD25), dos dois grupo de pacientes eritrodérmicos (grupo "reativo" e "micose fungóide / síndrome de Sézary") e de grupo controle normal foram avaliadas através do cálculo de suas medidas de tendência central (médias e medianas) e suas dispersões (desvios-padrão). Os pacientes com mais de um exame realizado (hemograma, avaliação da morfologia dos linfócitos e citometria de fluxo), antes de instituição de terapêutica específica para a doença em questão, tiveram todos os valores computados na análise das médias gerais. Dois casos do grupo "MF/SS" (casos 25 e 41 - anexo 7) com aberrações fenotípicas evidentes (perda da expressão dos marcadores CD4 e TCR $\alpha \beta$ ) foram propositalmente excluídos dos cálculos das médias e medianas, evitando-se, assim, tendência para valores 
artificialmente baixos. Estes casos foram considerados apenas na análise qualitativa do imunofenótipo.

Aberração fenotípica, definida como perda da expressão de determinado antígeno de células T maduras, foi pesquisada individualmente em cada exame de imunofenotipagem. Para os marcadores CD2, CD3, CD5 ou TCR $\alpha \beta$ considerou-se perda de expressão quando se observou evidente diminuição de seu valor percentual em relação aos outros marcadores de células T maduras para o mesmo caso. Para o marcador CD4 considerou-se perda de expressão quando seu valor percentual esteve reduzido abaixo do valor mínimo de referência estabelecido para o grupo controle e a soma deste valor de células T $\mathrm{CD}^{+}$com o valor percentual de células $\mathrm{T} \mathrm{CD}^{+}$e de células $\mathrm{TCR} \gamma \delta^{+}$foi inferior ao valor percentual total de linfócitos $\mathrm{CD}^{+}\left(\% \mathrm{CD} 4^{+}+\% \mathrm{CD}^{+}+\% \mathrm{TCR} \gamma \delta^{+}<\right.$ $\left.\% \mathrm{CD}^{+}\right)$. Para o $\mathrm{CD} 7$, considerou-se perda de expressão quando seu valor apresentou resultado nulo, o que não ocorreu em nenhum dos casos deste estudo.

O termo "linfoma cutâneo de células T" estará referindo-se, neste trabalho, indistintamente à "micose fungóide" e à "síndrome de Sézary".

\section{3. ANÁLISE ESTATÍSTICA}

Médias e desvios-padrão foram calculadas para as variáveis demográficas, valores de leucócitos, linfócitos, eosinófilos, células de Sézary, 
linfócitos pleomórficos e valores percentuais dos linfócitos imunofenotipicamente marcados. Avaliou-se a condição de normalidade da distribuição das variáveis através do Teste de Levene. As variáveis que satisfizeram a condição de normalidade foram comparadas pelo Teste $t$ de Student e àquelas que se distribuíram de modo não paramétrico foram comparadas pelo Teste da Mediana e Teste de Mann-Whitney, estabelecendose nível de significância de 5\% (anexos 11-13). Os valores de referência utilizados para a avaliação da existência de aberrações fenotípicas, nos pacientes deste estudo, provieram do grupo controle normal composto por indivíduos sãos sem enfermidades cutâneas, linfoproliferativas ou imunodeficiências (anexo 15).

\subsection{ASPECTOS ÉTICOS E LEGAIS}

O presente estudo foi aprovado pelo Conselho do Departamento de Dermatologia da Faculdade de Medicina da Universidade de São Paulo e pela Comissão de Ética em Pesquisa da Diretoria Clínica do Hospital das Clínicas da Faculdade de Medicina da Universidade de São Paulo. Os doadores voluntários que constituíram o grupo controle normal haviam sido esclarecidos sobre o protocolo de pesquisa e assinaram o Termo de Consentimento Livre e Esclarecido. 
4. RESULTADOS 


\subsection{Dados demográficos}

Trinta e sete pacientes eritrodérmicos, protocolados consecutivamente, foram subdivididos, de acordo com a conclusão diagnóstica, em dois grupos: "reativo" e "micose fungóide / síndrome de Sézary (MF/SS)". O grupo "reativo" compôs-se de pacientes com dermatite atópica $(n=6)$, eczema $(n=4)$, psoríase $(n=8)$, farmacodermias (excetuando farmacodermia por anticonvulsivantes) $(n=3)$ e neoplasias viscerais $(n=3)$. O grupo "MF/SS" compôs-se de pacientes com micose fungóide eritrodérmica $(n=8)$ e síndrome de Sézary $(n=5)$ As tabelas 1, 2, 3 e 4 demonstram, respectivamente, as médias das idades com seus desvios-padrão, a distribuição por sexo, por cor e o tempo de evolução do quadro de eritrodermia até a primeira consulta, para os dois grupos de 
pacientes. Para todo o grupo, houve predomínio do sexo masculino na proporção de 2,7 homens para cada mulher, e distribuição semelhante para indivíduos brancos e não brancos. O maior tempo médio de evolução foi observado para o grupo "MF/SS".

Tabela 1 - Média da idades e desvios-padrão para os grupos de pacientes eritrodérmicos

\begin{tabular}{|c|c|c|c|}
\hline & NORMAL & REATIVO & MF/SS \\
\hline IDADE EM ANOS & $42,50 \pm 17,59$ & $53,50 \pm 20,28$ & $62,15 \pm 13,48$ \\
\hline
\end{tabular}

Tabela 2 - Distribuição para os sexos entre os grupos de pacientes eritrodérmicos

\begin{tabular}{l|cccc}
\hline & REATIVO & MF/SS & TOTAL \\
\hline MASCULINO & $18(75,00 \%)$ & 9 & $(69,20 \%)$ & $27 \quad(73,00 \%)$ \\
FEMININO & $6(25,00 \%)$ & 4 & $(30,80 \%)$ & $10(27,00 \%)$ \\
\hline TOTAL & $24(100,00 \%)$ & $13(100,00 \%)$ & $37(100,00 \%)$ \\
\hline
\end{tabular}

Tabela 3 - Distribuição conforme a cor entre os grupos de pacientes eritrodérmicos

\begin{tabular}{l|ccc}
\hline & REATIVO & MF/SS & TOTAL \\
\hline BRANCA & $16(69,50 \%)$ & $4 \quad(30,80 \%)$ & $20(55,60 \%)$ \\
PARDA & $6(26,10 \%)$ & $7(53,80 \%)$ & $13(36,10 \%)$ \\
NEGRA & $1 \quad(4,30 \%)$ & $2(15,40 \%)$ & $3(8,30 \%)$ \\
\hline TOTAL & $23(100,00 \%)$ & $13(100,00 \%)$ & $36(100,00 \%)$ \\
\hline
\end{tabular}


Tabela 4 - Média dos tempos de evolução do quadro cutâneo (eritrodermia) e desvios-padrão até a ocasião da primeira consulta para os grupos de pacientes eritrodérmicos

\begin{tabular}{l|cc}
\hline & REATIVO & MF/SS \\
\hline TEMPO DE EVOLUÇÃO & $11,43 \pm 13,02$ & $23,85 \pm 4,40$ \\
\hline
\end{tabular}

\subsection{Dados do hemograma e da morfologia dos linfócitos}

\subsubsection{Avaliação dos leucócitos, linfócitos e eosinófilos}

As contagens leucocitárias para os pacientes eritrodérmicos (grupos "reativo" e "MF/SS") apresentaram valores absolutos médios semelhantes entre si e maiores que para os indivíduos normais. Os valores absolutos de linfócitos apresentaram-se significativamente mais elevados no grupo "MF/SS" que no grupo "reativo" e "controles normais". O valor médio do número absoluto de eosinófilos esteve aumentado nos grupos de pacientes eritrodérmicos (grupos "reativo" e "MF/SS") em relação aos "controles normais", entretanto com comportamento igual entre os dois grupos de pacientes eritrodérmicos (tabela 5 , anexos 11-13). 
Tabela 5 - Valores médios e desvios-padrão das variáveis hematológicas para os grupos de pacientes eritrodérmicos

\begin{tabular}{|c|c|c|c|}
\hline & NORMAL & REATIVO & MF/SS \\
\hline LEUCÓCITOS & $6200,00 \pm 1557,50$ & $9802,96 \pm 2984,86$ & $17614,67 \pm 22228,31$ \\
\hline LINFÓCITOS & $1696,00 \pm 515,18$ & $1828,81 \pm 714,90$ & $9504,07 \pm 19774,49$ \\
\hline EOSINÓFILOS & $180,97 \pm 182,54$ & $703,89 \pm 568,01$ & $897,07 \pm 1072,50$ \\
\hline
\end{tabular}

As figuras 1 e 2 ilustram, através de gráfico tipo box-plot, as medidas de tendência central (medianas) e suas dispersões para as variáveis hematológicas estudadas.

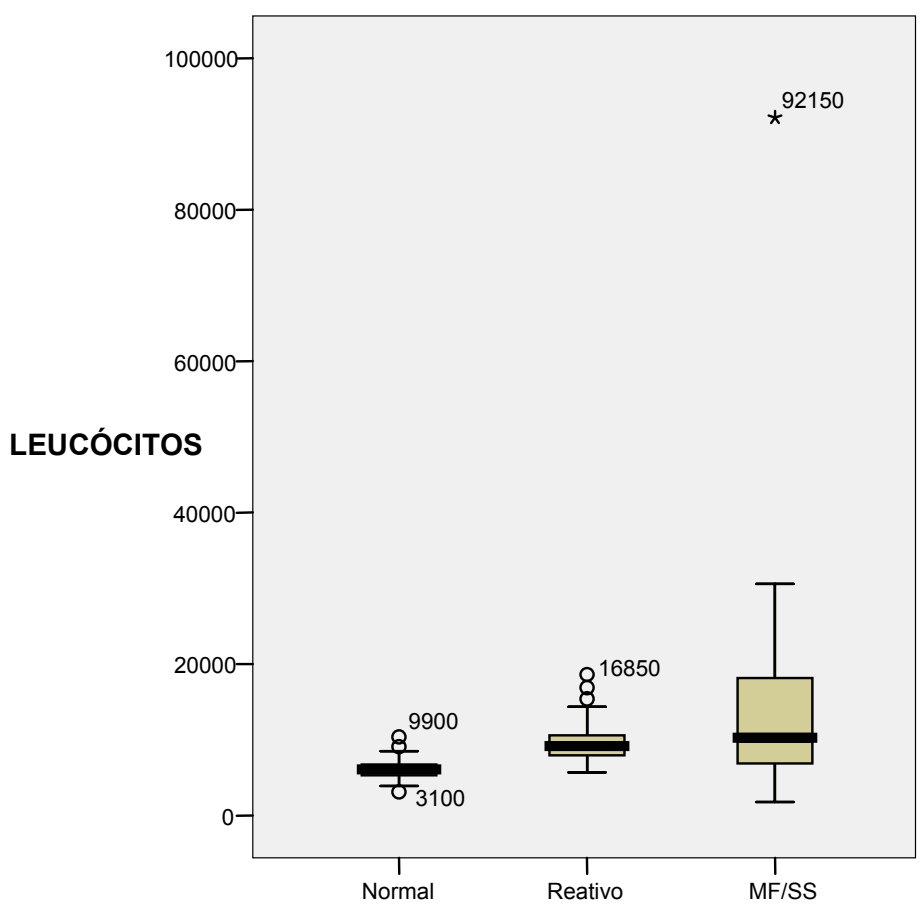

Figura 1 - Gráfico tipo box-plot demonstrando, comparativamente, mediana e dispersão para os leucócitos entre os grupos de pacientes eritrodérmicos e indivíduos normais 


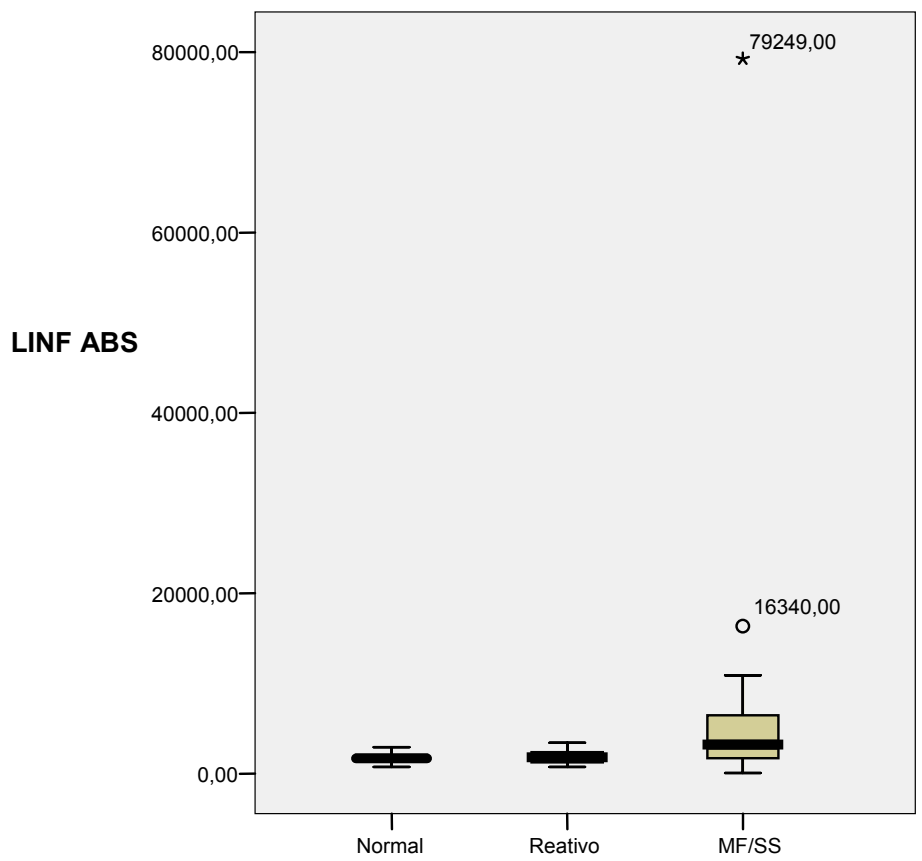

Figura 2 - Gráfico tipo box-plot demonstrando, comparativamente, mediana e dispersão para os linfócitos entre os grupos de pacientes eritrodérmicos e indivíduos normais

\subsubsection{Avaliação morfológica dos linfócitos}

O percentual de células de Sézary (\% CS), assim como de linfócitos pleomórficos (\% LP), foi maior para o grupo "MF/SS" que para o grupo "reativo" (tabela 6; figuras 3 e 4; anexo 11). Neste quesito não houve possibilidade de comparação com indivíduos normais por questões relativas à diferenças na metodologia utilizada. 
Tabela 6 - Valores médios e desvios-padrão dos linfócitos absolutos e do percentual de células de Sézary (\%CS) e de linfócitos pleomórficos (\%LP) no sangue periférico para os grupos de pacientes eritrodérmicos

\begin{tabular}{|c|c|c|c|}
\hline & NORMAL & REATIVO & MF/SS \\
\hline LINFÓCITOS ABSOLUTOS & $1696,00 \pm 515,18$ & $1828,81 \pm 714,90$ & $9504,07 \pm 19774,49$ \\
\hline$\%$ CS & - & $0,69 \pm 1,14$ & $7,50 \pm 12,97$ \\
\hline$\%$ LP & - & $2,28 \pm 4,76$ & $20,57 \pm 22,10$ \\
\hline
\end{tabular}

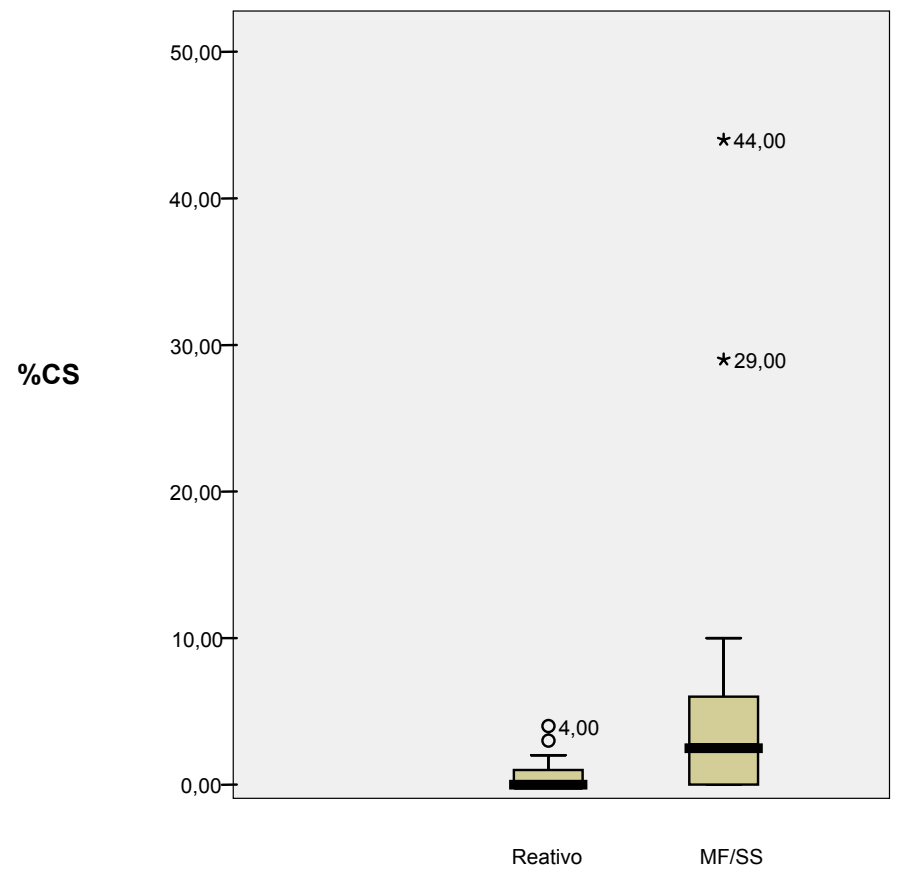

Figura 3 - Gráfico tipo box-plot demonstrando, comparativamente, mediana e dispersão para o percentual de células de Sézary entre os grupos de pacientes eritrodérmicos 


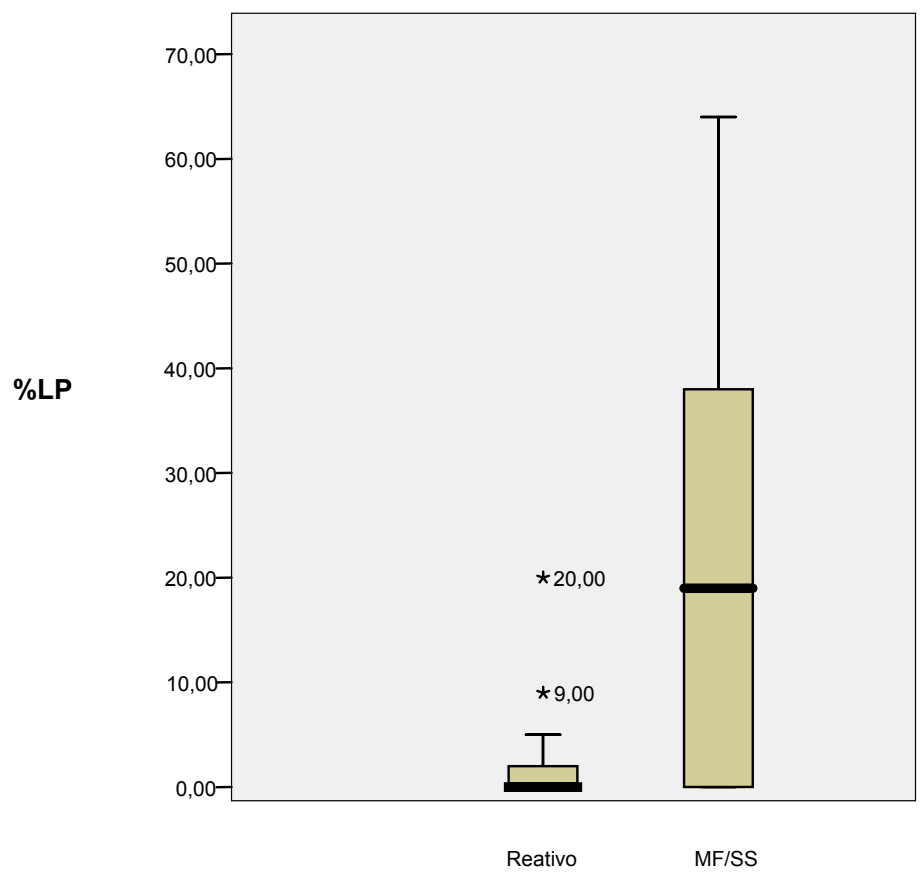

Figura 4 - Gráfico tipo box-plot demonstrando, comparativamente, mediana e dispersão para o percentual de linfócitos pleomórficos entre os grupos de pacientes eritrodérmicos

4.3. Dados quantitativos da imunofenotipagem dos linfócitos $T$ do sangue periférico pela citometria de fluxo

\subsubsection{Marcadores de linfócitos $T$ periféricos CD3, CD2, CD5,}

\section{CD7 e TCR $\alpha \beta$}

Em relação ao marcadores de células $T$ maduras, o percentual de linfócitos T CD3, CD3/CD2, CD3/CD5 e TCRaß mostrou-se com valores médios semelhantes entre os grupos de pacientes eritrodérmicos ("MF/SS" e "reativo") e os controles normais. Os pacientes com eritrodermias reativas apresentaram 
valores de $C D 3 / C D 2$ aumentados em relação aos indivíduos normais e aqueles com MF/SS apresentaram valores aumentados de CD3/CD5 em relação aos indivíduos normais. Os valores de linfócitos CD3/TCRaß apresentaram-se indistintamente aumentados nos dois grupos de pacientes eritrodérmicos em relação aos controles normais. (tabela 7; figuras 5-8; anexos 11-13).

Tabela 7 - Valores médios e desvios-padrão dos percentuais de linfócitos T CD3 total, $\mathrm{CD} 3 / \mathrm{CD} 2, \mathrm{CD} 3 / \mathrm{CD} 5, \mathrm{CD} 3 / \mathrm{TCR} \alpha \beta$ e CD3/CD7 estimados através da citometria de fluxo, no sangue periférico para os grupos de pacientes eritrodérmicos e controles normais

\begin{tabular}{l|rcr}
\hline & NORMAL & REATIVO & MF/SS \\
\hline \%CD3 TOTAL & $72,90 \pm 6,45$ & $75,87 \pm 7,74$ & $80,40 \pm 13,68$ \\
$\%$ CD3/CD2 & $68,26 \pm 6,73$ & $74,08 \pm 7,76$ & $75,80 \pm 14,31$ \\
$\%$ CD3/CD5 & $67,34 \pm 8,77$ & $71,38 \pm 7,96$ & $77,20 \pm 13,42$ \\
$\%$ CD3/TCRaß & $65,34 \pm 6,20$ & $71,30 \pm 8,65$ & $76,00 \pm 14,33$ \\
& $58,84 \pm 8,62$ & $61,02 \pm 12,67$ & $48,47 \pm 26,60$ \\
\hline
\end{tabular}

Os valores percentuais de linfócitos $C D 3 / C D 7$ foram semelhantes entre os grupos de pacientes eritrodérmicos e normais, embora as medidas de tendência central (média e mediana) pareçam ser mais baixas para o grupo "MF/SS". Observou-se, ainda, maior dispersão, para esses valores, no grupo "MF/SS" (tabela 7, figura 9; anexos 11-13). 


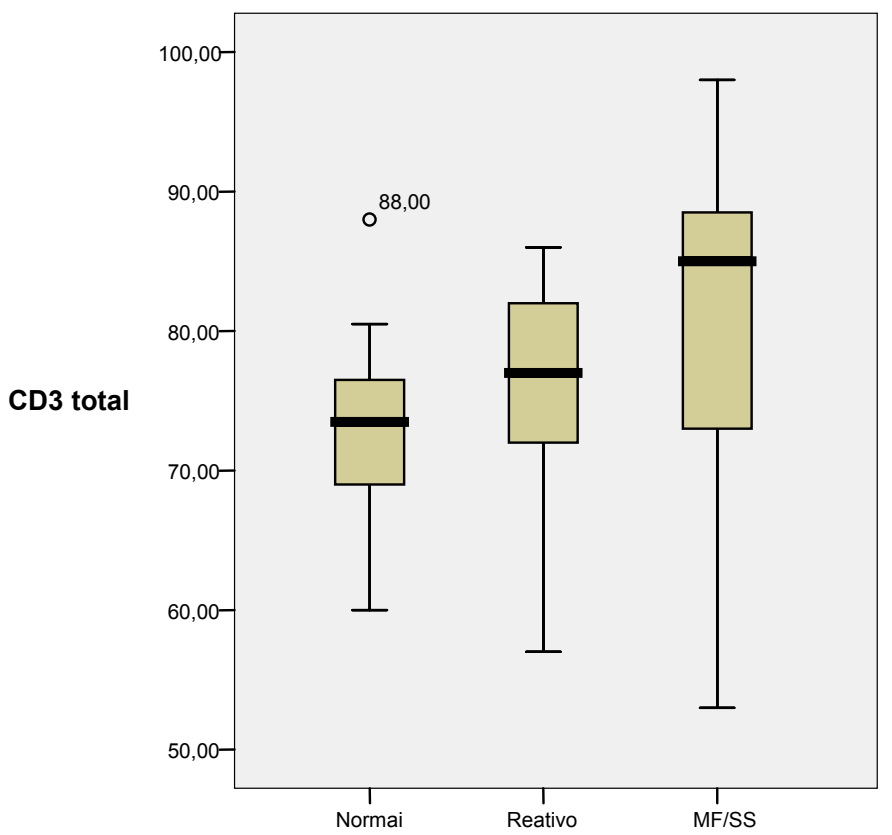

Figura 5 - Gráfico tipo box-plot demonstrando, comparativamente, mediana e dispersão para o percentual de linfócitos T CD3 total, estimados através da citometria de fluxo, entre os grupos de pacientes eritrodérmicos e controles normais

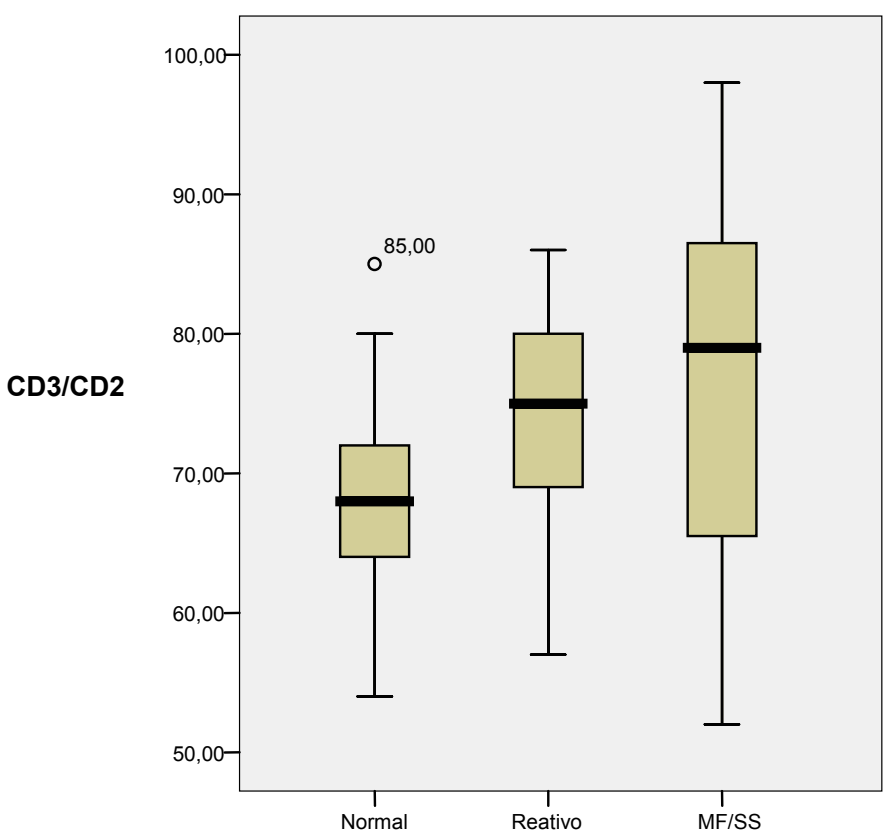

Figura 6 - Gráfico tipo box-plot demonstrando, comparativamente, mediana e dispersão para o percentual de linfócitos CD3/CD2, estimados através da citometria de fluxo, entre os grupos de pacientes eritrodérmicos e controles normais 


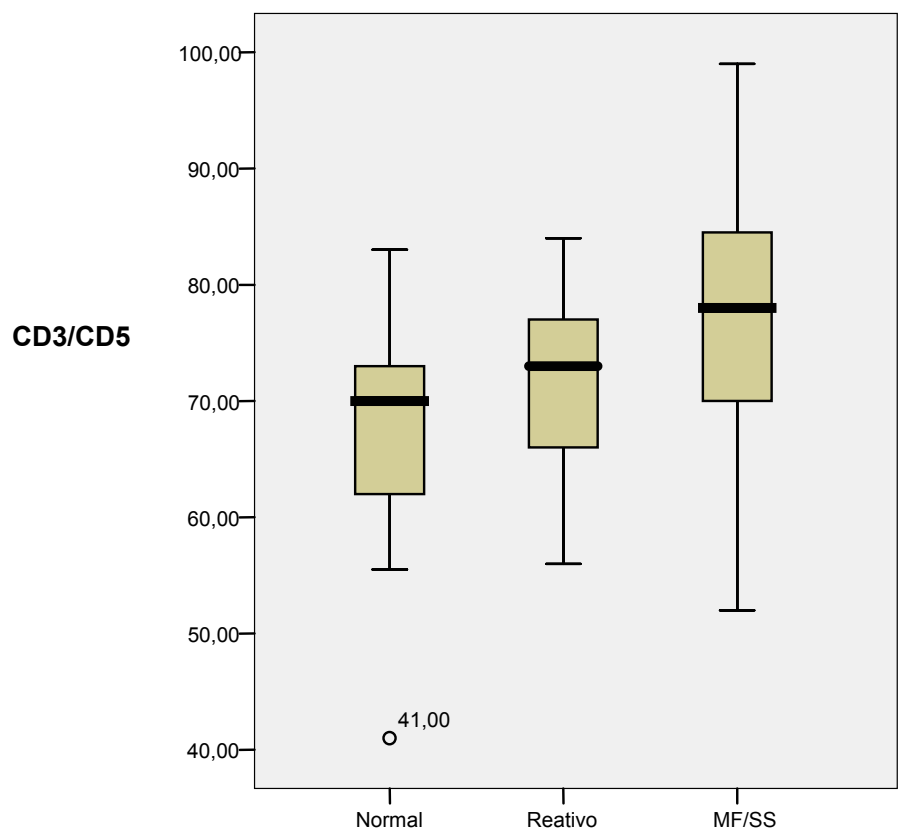

Figura 7 - Gráfico tipo box-plot demonstrando, comparativamente, mediana e dispersão para o percentual de linfócitos CD3/CD5, estimados através da citometria de fluxo, entre os grupos de pacientes eritrodérmicos e controles normais

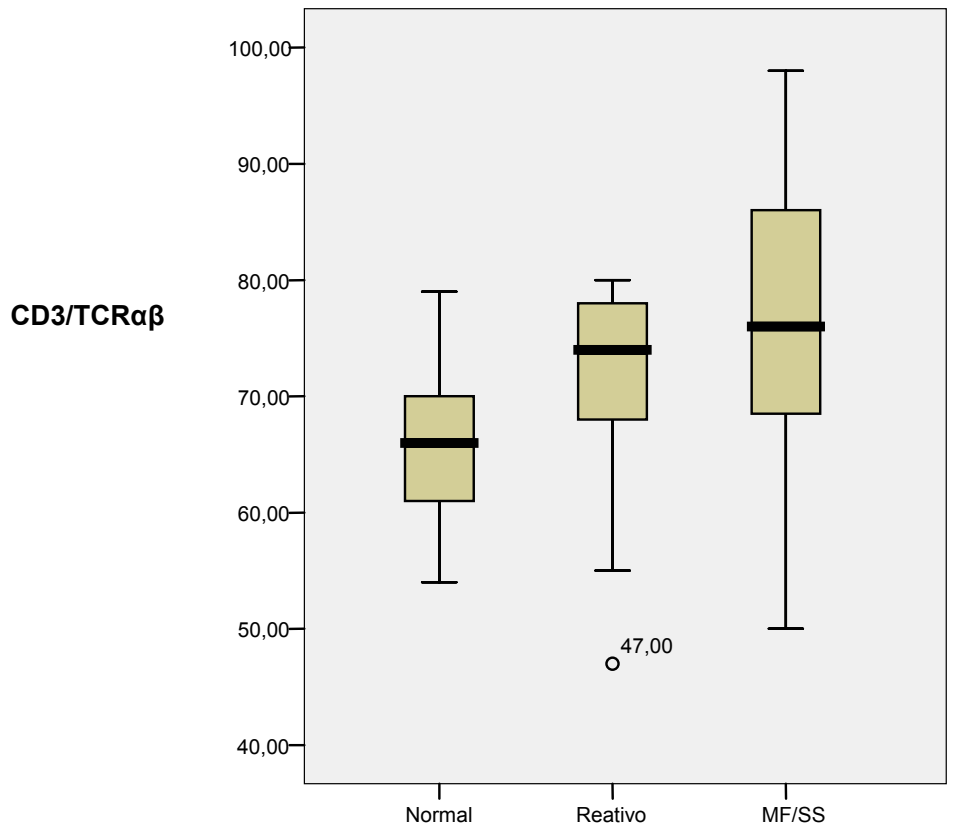

Figura 8 - Gráfico tipo box-plot demonstrando, comparativamente, mediana e dispersão para o percentual de linfócitos CD3/TCRaß, estimados através da citometria de fluxo, entre os grupos de pacientes eritrodérmicos e controles normais 


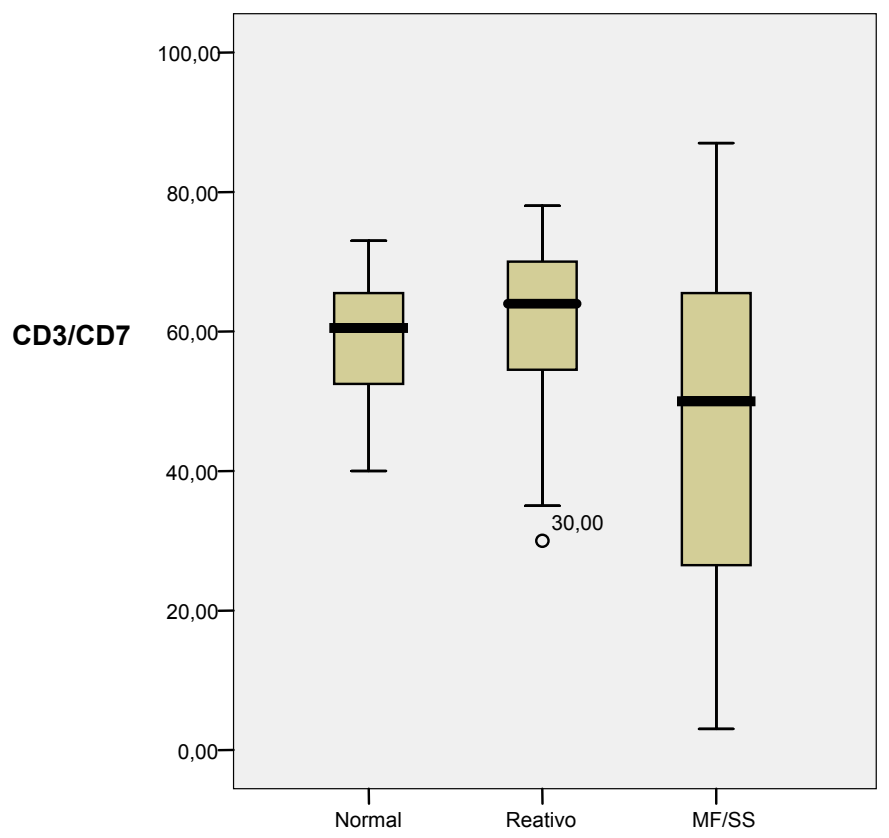

Figura 9 - Gráfico tipo box-plot demonstrando, comparativamente, mediana e dispersão para o percentual de linfócitos CD3/CD7, estimados através da citometria de fluxo, entre os grupos de pacientes eritrodérmicos e controles normais

\subsubsection{Marcadores de linfócitos T CD4 e relação CD4:CD8}

Os linfócitos CD3/CD4, assim como a relação CD4:CD8, mostraram-se significativamente aumentados para o grupo "MF/SS" em relação ao grupo "reativo" e "controles normais". Os valores de linfócitos CD3/CD8 distribuíramse de modo semelhante entre os indivíduos eritrodérmicos e normais (tabela 8, figuras 10 e 11; anexos 11-13). 
Tabela 8 - Valores médios e desvios-padrão dos percentuais de linfócitos CD3/CD4, CD3/CD8 e relação CD4:CD8 estimados através da citometria de fluxo, no sangue periférico para os grupos de pacientes eritrodérmicos e controles normais

\begin{tabular}{|c|c|c|c|}
\hline & NORMAL & REATIVO & MF/SS \\
\hline CD3/CD4 & $45,82 \pm 7,27$ & $47,15 \pm 11,71$ & $58,77 \pm 19,57$ \\
\hline CD3/CD8 & $24,78 \pm 6,90$ & $26,35 \pm 7,46$ & $19,57 \pm 12,76$ \\
\hline RELAÇÃO CD8:CD4 & $2,05 \pm 0,83$ & $2,04 \pm 1,13$ & $9,36 \pm 14,23$ \\
\hline
\end{tabular}

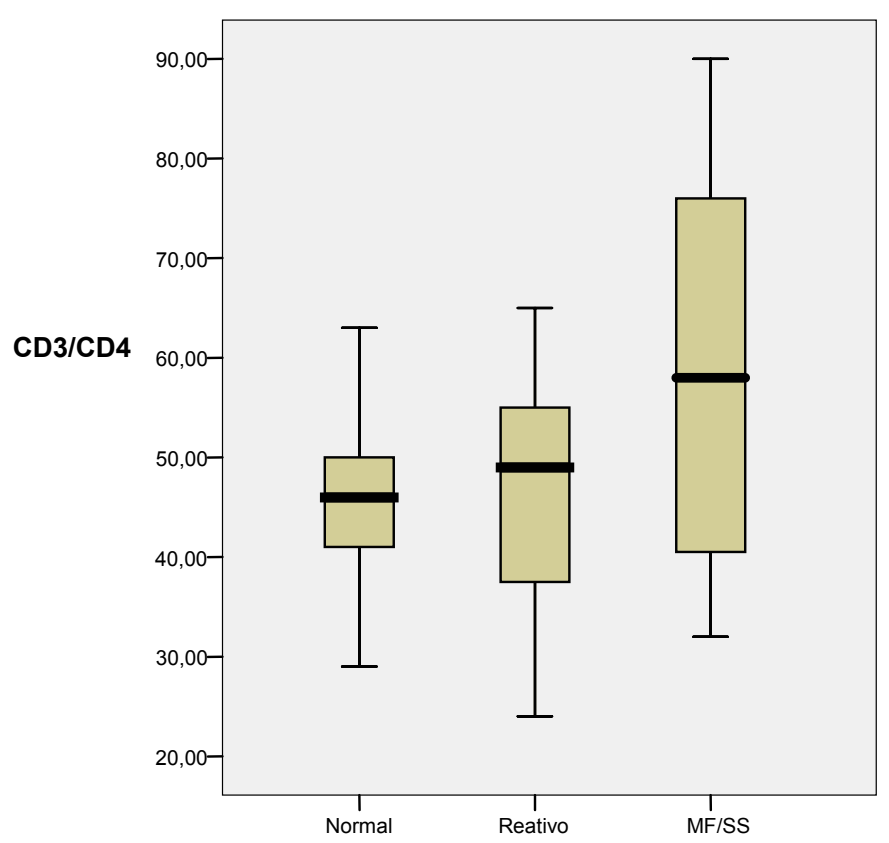

Figura 10 - Gráfico tipo box-plot demonstrando, comparativamente, mediana e dispersão para o percentual de linfócitos CD3/CD4, estimados através da citometria de fluxo, entre os grupos de pacientes eritrodérmicos e controles normais 


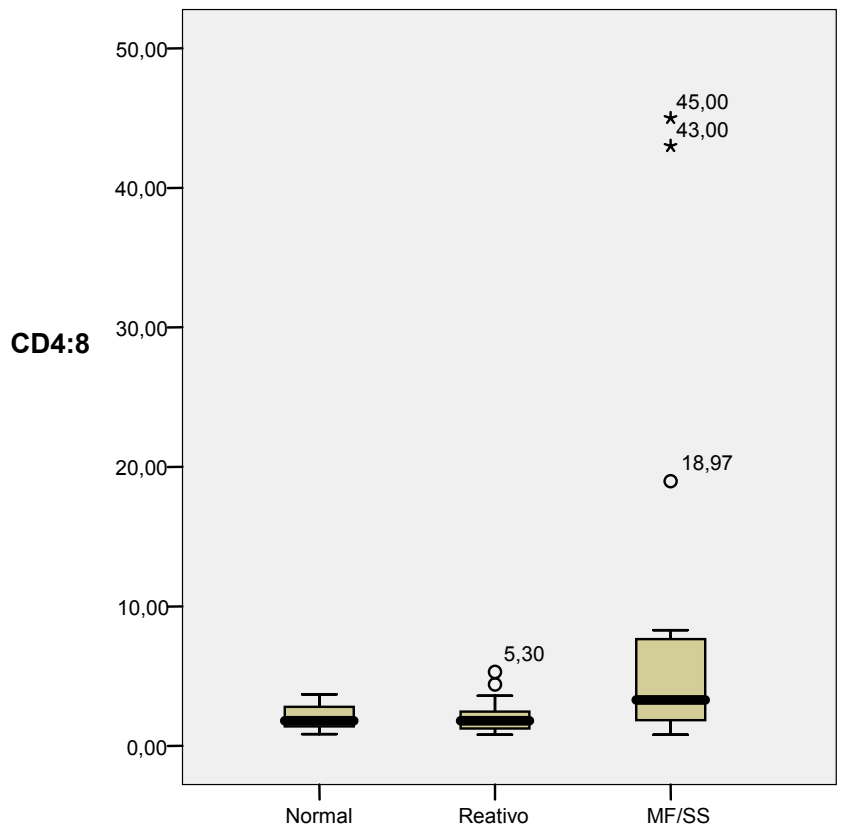

Figura 11 - Gráfico tipo box-plot demonstrando, comparativamente, mediana e dispersão para a relação CD4:CD8 entre os grupos de pacientes eritrodérmicos e controles normais

\subsubsection{Linfócitos T CD3 expressando CLA e CD25}

Valores percentuais elevados de linfócitos CD3/CLA e CD3/CD25 puderam ser observados nos dois grupos de pacientes eritrodérmicos. Entretanto os valores médios de linfócitos CD3/CLA mostraram-se semelhantes entre os pacientes eritrodémicos e normais. Linfócitos CD3 expressando CD25 estiveram aumentados indistintamente nos indivíduos eritrodérmicos (grupo "reativo" e grupo "MF/SS") em relação aos controles normais (tabela 9, figura 12 e 13; anexos 11-13). 
Tabela 9 - Valores médios e desvios-padrão dos percentuais de linfócitos CD3/CLA e CD3/CD25, estimados através da citometria de fluxo, no sangue periférico para os grupos de pacientes eritrodérmicos e controles normais

\begin{tabular}{|c|c|c|c|}
\hline & NORMAL & REATIVO & MF/SS \\
\hline CD3/CLA & $4,08 \pm 2,86$ & $5,48 \pm 5,79$ & $8,31 \pm 9,09$ \\
\hline CD3/CD25 & $9,70 \pm 5,87$ & $16,84 \pm 9,34$ & $22,23 \pm 13,50$ \\
\hline
\end{tabular}

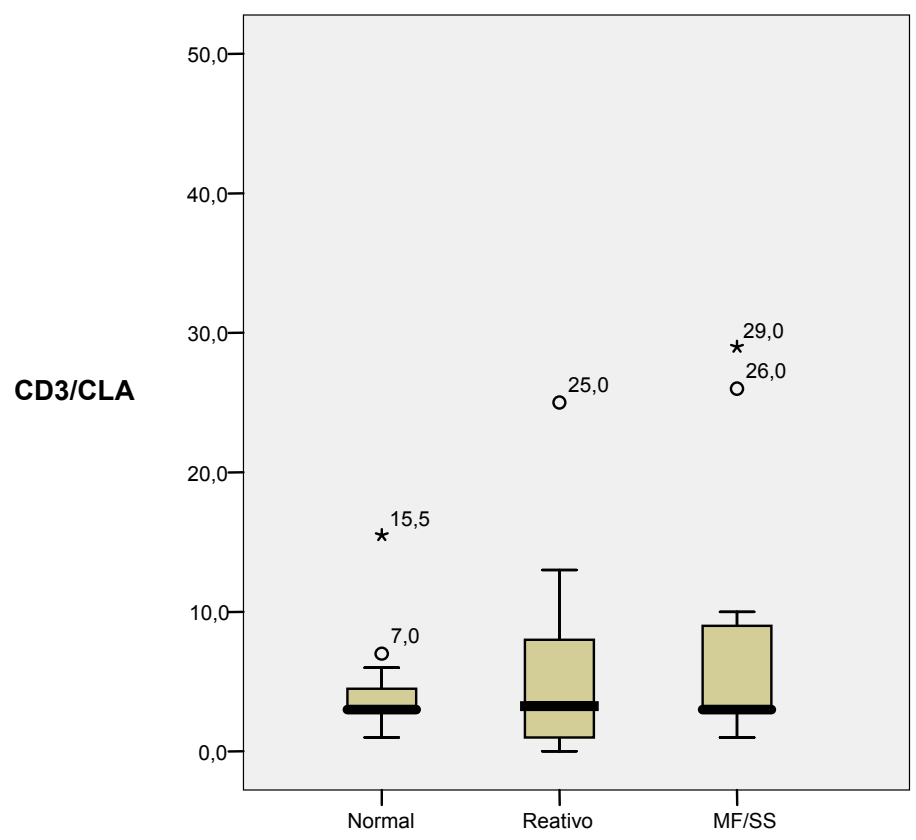

Figura 12 - Gráfico tipo box-plot demonstrando, comparativamente, mediana e dispersão para percentual de linfócitos CD3/CLA, estimados através da citometria de fluxo, entre os grupos de pacientes eritrodérmicos 


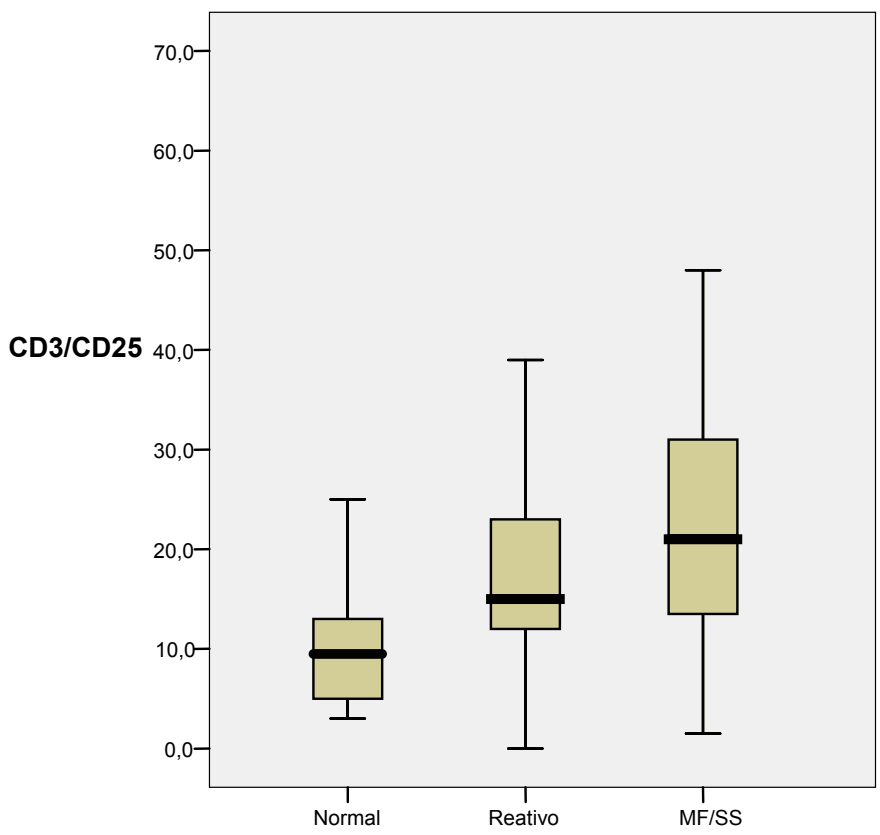

Figura 13 - Gráfico tipo box-plot demonstrando, comparativamente, mediana e dispersão para percentual de linfócitos CD3/CD25, estimados através da citometria de fluxo, entre os grupos de pacientes eritrodérmicos

\subsection{Dados qualitativos (fenótipos anômalos) da imunofenotipagem} dos linfócitos T do sangue periférico pela citometria de fluxo

\subsubsection{Perda da expressão de marcadores de linfócitos $\mathbf{T}$}

maduros

A expressão de fenótipo anômalo com perda de antígenos característicos de linfócitos $\mathrm{T}$ periféricos (maduros) foi evento muito raro, somente observado em dois casos de síndrome de Sézary (SS) do grupo 
"MF/SS". Valores muito baixos de células T expressando CD7 foram observados em dois casos de SS (tabela 10; anexo 7).

Tabela 10 -Perda de marcadores T na superfície dos linfócitos do sangue periférico analisado por citometria de para o grupo de indivíduos normais e para os grupos de pacientes eritrodérmicos e controles normais

\begin{tabular}{|c|c|c|c|}
\hline & NORMAL & REATIVO & MF/SS \\
\hline PERDA DE CD3/CD2 & - & - & 1 \\
\hline PERDA DE CD3/TCRaß & - & - & 1 \\
\hline PERDA DE CD3/CD4 & - & - & 2 \\
\hline VALORES BAIXOS DE CD3/CD7 & - & - & 2 \\
\hline
\end{tabular}

\subsubsection{Presença de populações linfocitárias de diferentes}

tamanhos

Presença evidente e discrepante de mais de uma população linfocitária foi observada em um paciente do grupo "reativo" e, em um paciente com SS do grupo "MF/SS" (tabela 11, figura 15). As três "subpopulações com diferentes tamanhos celulares" do caso com SS apresentaram fenótipo anômalo (perda de marcadores de linfócitos T maduros: CD2, CD4 e TCRaß), e expansão de células CD3, CD3/CD5 e CD3/CD25. O caso do grupo "reativo" (caso 9 - anexo 3), com diagnóstico de dermatite atópica, apresentou subpopulação de maior tamanho composta por células CD4/CD25. 
Tabela 11 - Presença de populações linfocitárias de diferentes tamanhos, avaliadas através da citometria de fluxo, no sangue periférico, para os grupos de pacientes eritrodérmicos

\begin{tabular}{|c|c|c|c|}
\hline & NORMAL & REATIVO & MF/SS \\
\hline DUAS POPULAÇÕES & - & 1 & - \\
\hline TRÊS POPULAÇÕES & - & - & 1 \\
\hline
\end{tabular}
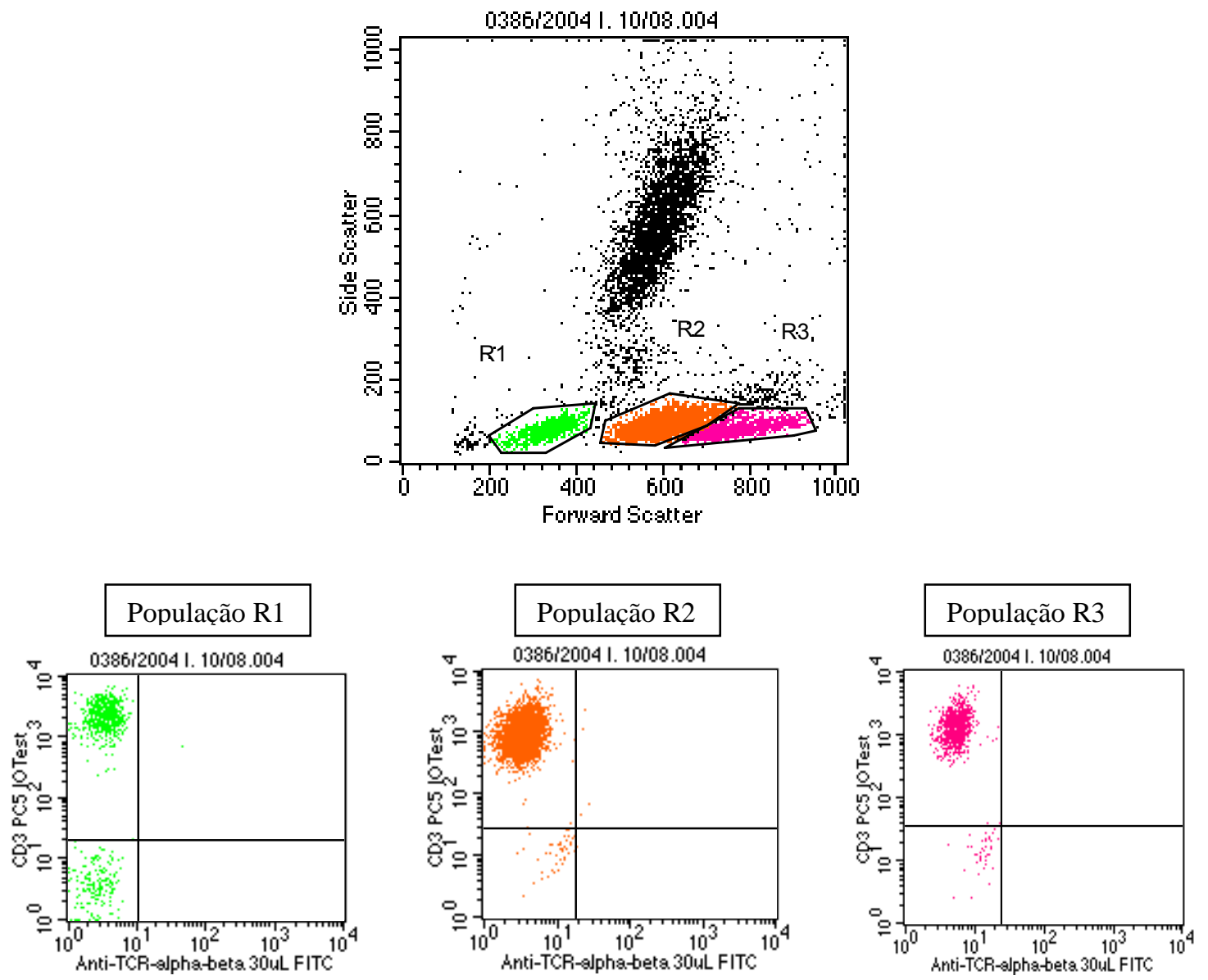

Figura 15 - Citometria de fluxo de paciente com síndrome de Sézary (caso 25). Presença de três populações linfocitárias com diferentes tamanhos $(R 1<R 2<R 3)$. Perda da expressão do receptor TCRaß na população linfocitária T CD3 de menor tamanho (R1), na população intermediária (R2) e na população de maior tamanho (R3). 
5. DISCUSSÃO 
A eritrodermia adquirida ou dermatite esfoliativa é condição cutânea que em decorrência da extensão de seu acometimento e da predominância em indivíduos acima dos 45 anos apresenta morbidade significativa. Sua freqüência está estimada em cerca de 3 casos para 10.000 consultas ambulatoriais (Rym et al., 2005), sendo que a maioria dos pacientes necessita internações prolongadas para cuidados clínicos devidos à gravidade, em potencial, desencadeada pela constante espoliação através da pele, pela dificuldade de manutenção da temperatura corpórea, e também pela dificuldade de definição etiológica (Sigurdsson et al., 1996; Rothe et al., 2005). A literatura faz referência à predominância no sexo masculino (Sehgal e Srivastava, 1986), fato também observado neste trabalho. Os quadros relacionados a dermatoses préexistentes, como psoríase, pitiríase rubra pilar, dermatite seborréica e aqueles 
causados por drogas, habitualmente, não apresentam dificuldades diagnósticas. Uma acurada história prévia de dermatoses potencialmente evolutivas para eritrodermias ou do contato com drogas desencadeantes de farmacodermias em associação com o exame histopatológico da pele lesada, habitualmente, corroboram o diagnóstico. A síndrome de Sézary, com seus quadros cutâneo e hematológico típicos, também não apresenta dificuldade para sua definição. Entretanto número considerável de pacientes (7,2 - 47\%) apresenta histórias e exames histopatológicos inconclusivos (Sehgal e Srivastava, 1986; Rym et al., 2005).

Do ponto de vista clínico, a despeito da literatura fazer referência a sinais que poderiam ser característicos de determinados diagnósticos, como presença de ilhotas de pele sã na pitiríase rubra pilar e nos linfomas cutâneos de células T, a maioria dos pacientes apresenta quadros extremamente monomórficos, difusamente infiltrados ou descamativos, e invariavelmente pruriginosos (Rothe et al., 2000; Sehgal et al., 2004). Em nossa experiência pessoal, no acompanhamento de coorte de pacientes ambulatoriais e internados na Divisão de Dermatologia do Hospital das Clínicas da FMUSP, cerca de 30\% apresentam evolução crônica de suas eritrodermias, que a despeito de realização periódica de exames histopatológicos, prosseguem sem definição diagnóstica. Fato interessante é que trabalho publicado em 1995, avaliando retrospectivamente 247 pacientes eritrodérmicos em período de 23 anos, neste mesmo hospital, evidencia idêntico número de percentual de casos classificados como idiopáticos (Vasconcellos et al., 1995). 
Vários estudos avaliam aspectos diversos do exame histopatológico como método auxiliar diagnóstico. Exames, cuidadosamente analisados, de biopsias contemporâneas, de diferentes áreas, assim como seriadas, poderiam incrementar sua capacidade diagnóstica pelo fato de que os achados histopatológicos diagnósticos da doença subjacente ficariam retidos na maioria dos casos (Botella-Estrada et al., 1994; Zipp et al., 1993). Há referências de que diagnóstico de psoríase poderia ser realizado em cerca de 60 a 90\% dos casos e de dermatites eczematosas em 65\% deles (Walsh et al., 1994; Tomasini et al., 1997). Entretanto, dermatites esfoliativas induzidas por drogas apresentam freqüentemente dermatites de interface indistinguíveis dos linfomas cutâneos epidermotrópicos (Sentis et al., 1986; Walsh et al., 1994), assim como casos inquestionáveis de síndrome de Sézary, com comprometimento hematológico e corroborado através de técnicas de biologia molecular, apresentam alterações histológicas inespecíficas (Trotter et al., 1997). Neste trabalho, pudemos observar que os exames histopatológicos apresentaram boa correlação diagnóstica para os casos classificados como reativos em decorrência de suas histórias de dermatoses pré-existentes, e evidente desencadeamento dos quadros de farmacodermia após a introdução de drogas com resolução do quadro quando da retirada das mesmas. Um caso típico de farmacodermia (caso 1, anexo 4, página 65) apresentou diagnóstico histopatológico de linfoma cutâneo, corroborando descrição da literatura (Sentis et al., 1986; Walsh et al., 1994). Dentre os casos com linfomas cutâneos, apenas um deles (caso 62, anexo 8, página 71), com síndrome de Sézary, apresentou múltiplas biopsias 
demonstrando tão somente diagnóstico de dermatite psoriasiforme e espongiótica. $\mathrm{Na}$ avaliação rotineira dos casos de eritrodermias sem adequada correlação entre o uso de drogas, de produtos aplicados topicamente, ou da evidência de dermatoses prévias temos podido observar que o exame histopatológico na maioria das vezes não é bom método diagnóstico. Dados da literatura fazem referência de que alguns quadros de eritrodermia com evolução crônica devem tratar-se de casos de linfomas cutâneos não passíveis de diagnóstico histológico (Sigurdsson et al., 1997).

Exames laboratoriais hematológicos e bioquímicos também não apresentam padrões diagnósticos para as diferentes causas de eritrodermia. Quadros típicos de farmacodermias por anticonvulsivantes, habitualmente, apresentam "rash" agudo com edema facial muito sugestivo, apresentam leucocitoses importantes, com linfocitoses e eosinofilias, elevação das enzimas hepatocelulares, lactato deidrogenase, e freqüentemente atipias linfocitárias, não raramente semelhantes às células de Sézary (Callot et al., 1996). Embora as alterações histológicas e laboratoriais destes pacientes possam ser superpostas àquelas dos linfomas cutâneos de células $T$, seus comemorativos clínicos e suas histórias corroboram o diagnóstico. Por este motivo, casos de farmacodermia por anticonvulsivantes foram propositalmente excluídos deste trabalho.

Não existem descrições de exames auxiliares significativos para as outras eritrodermias. Contagens elevadas de eosinófilos no sangue periférico estão descritas nas farmacodermias, na dermatite atópica e também nos 
linfomas cutâneos de células T. A despeito de haver referência a um pior prognóstico para os pacientes com linfomas cutâneos que se apresentam inicialmente com eosinofilia, não existem relatos de que estas células poderiam ser discriminatórias entre casos de eritrodermias reativas e eritrodermias por linfomas cutâneos (Tancrede-Bohin et al., 2004). Este trabalho também não evidenciou diferenças significativas entre os dois grupos de pacientes eritrodérmicos em relação a contagem absoluta de eosinófilos. Observou-se valores igualmente elevados para ambos os grupos quando comparados com os indivíduos normais. Nas síndromes de Sézary com acometimento hematológico inquestionável, com contagens muito elevadas de células de Sézary (> 20\%), com presença de células de Sézary grandes, blásticas, o diagnóstico é facilmente comprovado (Vonderheid, 2006). Pelos relatos da presença de células de Sézary em dermatoses benignas, farmacodermias, eritrodermias reativas e até mesmo em indivíduos normais, considera-se, atualmente, o encontro dessas células, no sangue periférico, um achado inespecífico, portanto não diagnóstico de linfoma cutâneo de células T. Por outro lado há que se considerar que a pesquisa de célula de Sézary é exaustiva, requer muita experiência na sua identificação e que os vários trabalhos que relatam a total inespecificidade destas células, utilizam métodos de análise totalmente diferentes, ora em esfregaços de sangue total, ora em concentrados leucocitários (Lutzner et al., 1971; Flaxman et al., 1971Guccion et al., 1979; Veelken et al., 1995). Estudo recente, avaliando cuidadosamente a quantidade de linfócitos normais, de linfócitos atípicos, de linfócitos com 
pleomorfismo nuclear e células com núcleos convolutos típicos para o diagnóstico de células de Sézary, com tamanhos pequeno a grande, demonstra a presença de células de Sézary e de linfócitos pleomórficos (em números percentuais) significantemente mais elevados nos casos com micose fungóide, mostrando-se uma ferramenta auxiliar importante na evidencia do comprometimento hematológico na micose fungóide (Oliveira, 2005). Neste trabalho foi possível evidenciar que os pacientes com eritrodermias por linfomas cutâneos apresentaram contagens linfocitárias totais, de linfócitos pleomórficos e de células de Sézary mais elevadas que aqueles com eritrodermia reativas e que os indivíduos normais. Não comparamos os parâmetros "células de Sézary" e "linfócitos pleomórficos" entre os indivíduos eritrodérmicos deste estudo e o grupo de indivíduos normais pois, para o referido grupo controle de indivíduos normais as contagens haviam sido realizadas em concentrados leucocitários estimando-se número de células anômalas para cada cem linfócitos, fato que poderia ter aumentado, a nosso ver, a sensibilidade do método. Somos da opinião que, quando adequadamente realizada, a avaliação morfológica dos linfócitos do sangue periférico é método bastante útil na abordagem de pacientes com suspeita de linfoma cutâneo de células T. Podemos afirmar que em nosso meio não foi freqüente o encontro de quantidades elevadas de células morfologicamente alteradas em indivíduos normais (Oliveira, 2005) assim como em pacientes com eritrodermias reativas.

Com a introdução da citometria de fluxo, permitindo, a avaliação do imunofenótipo de células em suspensão, vários trabalhos vem sendo 
desenvolvidos para se conhecer marcadores para os linfócitos neoplásicos do sangue periférico na síndrome de Sézary. A maioria dos trabalhos seleciona, para esta abordagem, células com aspecto neoplásico de pacientes com contagens bastantes elevadas de células de Sézary a procura de perfil fenotípico diagnóstico de linfomas cutâneos de células T. Aberrações fenotípicas, como perda da expressão de marcadores de células $T$ maduras (CD2, CD3, CD4, CD5 e CD7), têm se mostrado diagnósticas da síndrome de Sézary (Economidou et al., 1985; Bernengo et al., 1998; Vonderheid et al., 2002; Lima et al., 2003). Entretanto, são demonstráveis, na maioria da vezes, apenas em indivíduos com evidências adicionais da doença, conforme pudemos constatar neste nosso estudo. A expansão das células CD4, com relação CD4:CD8 > 10, também tem sido evidenciada nestes mesmos casos, adotando-se, atualmente, tais critérios para o diagnóstico de envolvimento hematológico nos LCCT e da síndrome de Sézary (Vonderheid et al., 2002). A despeito de termos estudado populações linfocitárias CD3 totais, provavelmente contemplando linfócitos possivelmente neoplásicos, reativos e normais, e não apenas população de células anômalas, pudemos observar, neste trabalho, que as médias das células T CD3/CD4 encontraram-se significativamente mais elevadas para os pacientes com eritrodermias por linfomas cutâneos de células T em relação aos pacientes com eritrodermias reativas e indivíduos normais. $\mathrm{O}$ valor percentual mais elevado de linfócitos CD3/CD4 encontrado para o grupo de pacientes com eritrodermias reativas foi igual a 65 (caso 50 com diagnóstico de dermatite atópica e caso 54 com diagnóstico de eczema - anexo 3, página 
62). Cinco casos de linfomas cutâneos de células T (5/13) apresentaram valores de linfócitos CD3/CD4 > 65, variando entre $67,5 \%$ e $90 \%$, denotando expansões dessa população. Embora, com a metodologia utilizada não seja possível fazer referência à clonalidade dessa expansão, e tampouco foi nossa pretensão, tais valores podem ser considerados úteis no diagnóstico de linfoma cutâneo de células $T$, pois não foi observado correntemente nas eritrodermias reativas. Trabalho recente demonstra, para o mesmo grupo de indivíduos normais utilizados para este presente estudo, relação CD4:CD8 invariavelmente inferior a quatro (CD4:CD8 < 4) (anexo 15, página 78). Neste estudo encontramos apenas dois pacientes com eritrodermia reativa (2/24) com valores maiores que 4 (caso 9, com diagnóstico de dermatite atópica, relação CD4:CD8 $=5,3$ e caso 28 com diagnóstico de farmacodermia, relação CD4:CD8 $=4,4$ ) (anexo 3, página 62). Para os casos de linfomas cutâneos de células T observou-se seis casos (6/13) com relação CD4:CD8 > 4, variando entre 4,2 e 45. Pode-se observar, inclusive, elevação desses valores em exames realizados consecutivamente, corroborando a relevância dessa análise.

A expressão do antígeno linfocitário cutâneo (CLA) nos linfócitos T totais mostrou-se com valores médios semelhantes para os pacientes com eritrodermias, assim como para os indivíduos normais. Os valores percentuais mais elevados de células T CD3/CLA, no grupo de eritrodermias reativas, foram observados nos pacientes com farmacodermias (caso 1, 28 e 60). Este dado é relatado na literatura para farmacodermias por anticonvulsivantes (Leyva et al., 2000). 
A expressão do receptor de IL-2 (CD25) mostrou-se aumentada nos pacientes eritrodérmicos em relação aos normais, mas não foi discriminatória entre os pacientes com eritrodermias reativas e aqueles com linfomas cutâneos de células T. Atualmente, dá-se importância para a avaliação do percentual de linfócitos CD4 neoplásicos que expressam CD25, nos linfomas cutâneos, na avaliação para indicação do uso de droga (denileukin diftox) que atua através da ligação com esses receptores (Foss, 2001; Lima et al., 2003).

Os dados deste trabalho puderam demonstrar que mesmo a simples análise quantitativa dos linfócitos $T$ totais CD3/CD4, CD3/CD8, a contagem linfocitária dos linfócitos no hemograma e a análise cuidadosa de alterações morfológicas linfocitárias em esfregaços de sangue periférico devem ser utilizadas na rotina diagnóstica de pacientes eritrodérmicos. Prosseguimos, entretanto, incluindo novos casos com o intuito de aumentar esta casuística. Os linfócitos do sangue periférico e fragmentos de lesões cutâneas destes pacientes com eritrodermias reativas e com linfomas cutâneos de células $T$, assim como de pacientes com eritrodermias idiopáticas, estão, também, sendo submetidos à análises moleculares para pesquisa do rearranjo gênico para o TCR. O objetivo é verificar possível correlação dos achados deste estudo com a presença de clonalidade de células T CD4 nos pacientes com eritrodermias idiopáticas. 
6. CONCLUSÕES 
Considerando-se que o número absoluto de linfócitos, o percentual de células de Sézary, de linfócitos pleomórficos e de subpopulação de linfócitos T CD3/CD4, assim como a relação CD4:CD8, estiveram significativamente aumentados nos pacientes eritrodérmicos com diagnóstico de micose fungóide/síndrome de Sézary em relação aos pacientes com eritrodermias reativas e indivíduos normais e, que aberrações fenotípicas, como perda de marcadores de células $\mathrm{T}$ maduras (CD2, CD4, TCRaß) foram observadas exclusivamente na síndrome de Sézary, pôde-se concluir que:

1. A análise quantitativa dos linfócitos no hemograma, a avaliação percentual de células de Sézary e linfócitos pleomórficos por cem leucócitos em esfregaços de sangue periférico e, a quantificação das 
subpopulações linfocitárias T CD3/CD4, CD3/CD8 e o cálculo da razão CD4:CD8, através da citometria de fluxo, podem ser consideradas ferramentas auxiliares contributivas para o diagnóstico de micose fungóide em eritrodermias idiopáticas.

2. A análise qualitativa (aberrações fenotípicas) das subpopulações linfocitárias T maduras podem corroborar o diagnóstico de síndrome de Sézary. 
7. ANEXOS 
ANEXO 1 - Descrição do grupo de pacientes denominado "REATIVO" de acordo com a idade, sexo, cor, antecedentes pessoais (AP), uso de drogas, diagnóstico final, tempo de evolução em meses na ocasião da primeira avaliação (Tev), tempo de seguimento em meses (Tseg), tratamento e evolução na última observação ou óbito

\begin{tabular}{|c|c|c|c|c|c|c|c|c|c|c|c|}
\hline N. & Nome & Idade & Sexo & Cor & AP & Drogas & Diag. final & Tev & Tseg & Tratamento & Evolução \\
\hline 9 & CMS & 15 & $\mathrm{~F}$ & B & Atopia & $\begin{array}{r}\text { Corticoterapia } \\
\text { Tópica }\end{array}$ & D. atópica & 24 & 1 & $\begin{array}{r}\text { Corticoterapia } \\
\text { Tópica } \\
\text { HDZ } \\
\end{array}$ & VCED \\
\hline 12 & DIC & 13 & $\mathrm{~F}$ & B & Atopia & $\begin{array}{r}\text { Corticoterapia } \\
\text { tópica }\end{array}$ & D. atópica & 24 & 11 & $\begin{array}{r}\text { Corticoterapia } \\
\text { tópica } \\
\text { HDZ }\end{array}$ & VCED \\
\hline 50 & MPRP & 55 & $\mathrm{~F}$ & $N$ & - & - & D. atópica & 0 & 3 & $\begin{array}{r}\text { Corticoterapia } \\
\text { tópica } \\
\text { HDZ } \\
\end{array}$ & VCED \\
\hline 66 & TCR & 28 & M & B & Atopia & - & D. atópica & 28 & 2 & $\begin{array}{r}\text { Corticoterapia } \\
\text { tópica }\end{array}$ & VCED \\
\hline 67 & TCC & 19 & M & B & Atopia & $\begin{array}{r}\text { Corticoterapia } \\
\text { tópica }\end{array}$ & D. atópica & 12 & 20 & $\begin{array}{r}\text { Corticoterapia } \\
\text { tópica }\end{array}$ & VCED \\
\hline 70 & WAS & 27 & M & B & - & - & D. atópica & 36 & 4 & $\begin{array}{r}\text { Corticoterapia } \\
\text { tópica }\end{array}$ & VCED \\
\hline 5 & ASS & 81 & M & $\mathrm{Pa}$ & $\begin{array}{r}\mathrm{HP} \\
\text { Estrogil.. } \\
\end{array}$ & - & Eczema & 5 & 24 & $\begin{array}{r}\text { Corticoterapia } \\
\text { tópica }\end{array}$ & VCED \\
\hline 54 & NLS & 51 & $\mathrm{~F}$ & $\mathrm{~Pa}$ & - & - & Eczema & 1 & 47 & $\begin{array}{r}\text { Corticoterapia } \\
\text { tópica } \\
\end{array}$ & VSED \\
\hline 69 & WG & 40 & M & $\mathrm{Pa}$ & - & $\begin{array}{r}\text { Aroeira } \\
\text { Barbatimão } \\
\end{array}$ & Eczema & 6 & 41 & PDN & VSED \\
\hline 71 & WK & 80 & M & B & $\begin{array}{r}\text { HAS } \\
\text { DPOC } \\
\text { Asma }\end{array}$ & $\begin{array}{r}\text { Clortalidona } \\
\text { Teofilina } \\
\text { Ipratrópio } \\
\text { Fenoterol }\end{array}$ & Eczema & 4 & 5 & PDN & VCED \\
\hline 2 & ASM & 54 & $\mathrm{~F}$ & B & - & Acitretin & $\begin{array}{r}\text { Psoríase/ } \\
\text { PRP? }\end{array}$ & 36 & 26 & Ciclosporina & VCED \\
\hline 20 & GDS & 68 & M & B & - & - & $\begin{array}{r}\text { Psoríase/ } \\
\text { PRP? }\end{array}$ & 2 & 51 & Acitretin & VCED \\
\hline 11 & CFC & 66 & $M$ & $B$ & Psoríase & - & Psoríase & 6 & 44 & Acitretin & VCED \\
\hline 13 & EMS & 56 & M & B & $\begin{array}{r}\text { Psoríase } \\
\text { Artrite pso. }\end{array}$ & - & Psoríase & 36 & 18 & Acitretin & VCED \\
\hline 17 & FMS & 70 & $\mathrm{~F}$ & - & Psoríase & - & Psoríase & - & 4 & Acitretin & VSED \\
\hline 34 & JMS & 56 & M & $\mathrm{Pa}$ & HAS & $\begin{array}{c}\text { Captopril } \\
\text { Acietrin }\end{array}$ & Psoríase & 24 & 40 & Acitretin & VCED \\
\hline 44 & LPR & 45 & M & $\mathrm{Pa}$ & Artrite pso. & $\begin{array}{r}\text { Corticoterapia } \\
\text { tópica } \\
\end{array}$ & Psoríase & 3 & 52 & Acitretin & VCED \\
\hline 65 & SCJ & 65 & $M$ & B & Psoríase & - & Psoríase & 3 & 4 & - & VCED \\
\hline 1 & $A X$ & 74 & M & B & $\begin{array}{r}\text { IRC dialítica } \\
\text { ITU }\end{array}$ & $\begin{array}{r}\text { Ciprofloxacina } \\
\text { Ceftriaxona } \\
\text { Vancomicina } \\
\end{array}$ & $\begin{array}{r}\text { Farmacodermia } \\
\text { ( } 2 \text { episódios })\end{array}$ & 0 & 12 & $\begin{array}{r}\text { Retirada das } \\
\text { drogas }\end{array}$ & VSED \\
\hline 28 & JJG & 70 & M & B & HAS & Furosemida & Farmacodermia & 0 & 36 & $\begin{array}{r}\text { Retirada das } \\
\text { drogas }\end{array}$ & VSED \\
\hline 60 & RJCS & 51 & M & B & $\begin{array}{l}\text { Alergias } \\
\text { cutâneas }\end{array}$ & Cefalexina & Farmacodermia & 1 & 47 & $\begin{array}{r}\text { PDN } \\
\text { Corticoterapia } \\
\text { tópica } \\
\end{array}$ & VSED \\
\hline 37 & $\mathrm{JM}$ & 66 & M & B & - & - & $\begin{array}{r}\text { Neoplasia } \\
\text { de colon }\end{array}$ & 2 & 27 & $\begin{array}{r}\text { Corticoterapia } \\
\text { tópica } \\
\text { Polipectomia }\end{array}$ & VCED \\
\hline 27 & JHB & 73 & M & B & $\begin{array}{r}\text { Asma; } \\
\text { DPOC; } \\
\text { Pancreatite } \\
\end{array}$ & - & $\begin{array}{r}\text { Neoplasia } \\
\text { de papilla }\end{array}$ & 6 & 5 & $\begin{array}{r}\text { PDN } \\
\text { Corticoterapia } \\
\text { tópica } \\
\end{array}$ & $\begin{array}{l}\text { MCED } \\
\text { Sepse }\end{array}$ \\
\hline 59 & PBM & 61 & M & $\mathrm{Pa}$ & $\begin{array}{l}\text { Dermatite } \\
\text { seborréica }\end{array}$ & - & $\begin{array}{l}\text { Neoplasia de } \\
\text { seio piriforme }\end{array}$ & 4 & 9 & $\begin{array}{r}\text { Corticoterapia } \\
\text { tópica } \\
\text { Cirurgia } \\
\text { radioterapia }\end{array}$ & VCED \\
\hline
\end{tabular}

VCED: vivo com evidência de doença; VSED: vivo sem evidência de doença: MCED: morto com evidência de doença: MSED: morto sem evidência de doença; HP: hiperplasia prostática; HAS: hipertensão arterial sistêmica; ITU: infecção do trato urinário; PRP: pitiríase rubra pilar 
ANEXO 2 - Descrição das variáveis hematológicas: leucócitos,

número relativo de linfócitos (LINF \%), número absoluto de linfócitos (LINF ABS), número relativo de eosinófilos (EOS \%), número absoluto de eosinófilos (EOS ABS), percentual de células de Sézary (\% CS) e de linfócitos pleomórficos (\% LP) para o grupo de pacientes denominado "REATIVO"

\begin{tabular}{|c|c|c|c|c|c|c|c|}
\hline N. & LEUCócITOS & LINF \% & LINF ABS & EOS \% & EOS ABS & $\% c s$ & \%LP \\
\hline 9 & 12620 & $19,8 \%$ & 2499 & $5,0 \%$ & 631 & $2,0 \%$ & $0,0 \%$ \\
\hline 12 & 8440 & $29,0 \%$ & 2448 & $16,0 \%$ & 1350 & $0,0 \%$ & $0,0 \%$ \\
\hline 50 & 8960 & $30,0 \%$ & 2688 & $17,0 \%$ & 1523 & $4,0 \%$ & $0,0 \%$ \\
\hline 66 & 5700 & $32,3 \%$ & 1841 & $11,9 \%$ & 969 & $0,0 \%$ & \\
\hline 67 & 8270 & $19,0 \%$ & 1571 & $23,0 \%$ & 1902 & $0,0 \%$ & $9,0 \%$ \\
\hline 70 & 6770 & $13,9 \%$ & 941 & $6,8 \%$ & 460 & $0,0 \%$ & $0,0 \%$ \\
\hline 5 & 7900 & $20,0 \%$ & 1580 & $15,0 \%$ & 1185 & $2,0 \%$ & $0,0 \%$ \\
\hline 54 & 10800 & $17,0 \%$ & 1836 & $2,0 \%$ & 216 & $0,0 \%$ & $0,0 \%$ \\
\hline 69 & 12160 & $17,0 \%$ & 2067 & $5,0 \%$ & 608 & $0,0 \%$ & $5,0 \%$ \\
\hline 71 & 9200 & $12,0 \%$ & 1104 & $11,0 \%$ & 1012 & $0,0 \%$ & $0,0 \%$ \\
\hline 2 & 8420 & $29,0 \%$ & 2442 & $2,0 \%$ & 168 & $0,0 \%$ & $2,0 \%$ \\
\hline 20 & 6600 & $20,0 \%$ & 1320 & $2,0 \%$ & 132 & $1,0 \%$ & $0,0 \%$ \\
\hline 11 & 9220 & $33,0 \%$ & 3043 & $4,0 \%$ & 369 & $0,0 \%$ & $0,0 \%$ \\
\hline $13 \mathrm{~A}$ & 14350 & $8,3 \%$ & 1191 & $2,1 \%$ & 301 & $0,0 \%$ & $0,0 \%$ \\
\hline $13 \mathrm{~B}$ & 6670 & $30,3 \%$ & 2021 & $2,8 \%$ & 187 & $0,0 \%$ & $0,0 \%$ \\
\hline 17 & 15840 & $8,8 \%$ & 1394 & $0,3 \%$ & 47 & $0,0 \%$ & $0,0 \%$ \\
\hline 34 & 9080 & $31,0 \%$ & 2815 & $8,0 \%$ & 726 & $0,0 \%$ & $5,0 \%$ \\
\hline 44 & 9700 & $18,0 \%$ & 1746 & $4,0 \%$ & 388 & $1,0 \%$ & $0,0 \%$ \\
\hline 65 & 9530 & $20,9 \%$ & 1992 & $1,8 \%$ & 171 & $0,0 \%$ & $0,0 \%$ \\
\hline $1 \mathrm{~A}$ & 6500 & $14,3 \%$ & 929 & $0,2 \%$ & 13 & $0,0 \%$ & - \\
\hline $1 \mathrm{~B}$ & 10400 & $8,0 \%$ & 832 & $3,0 \%$ & 832 & $1,0 \%$ & $2,0 \%$ \\
\hline 28 & 7300 & $10,0 \%$ & 730 & $2,0 \%$ & 146 & $0,0 \%$ & $5,0 \%$ \\
\hline $60 \mathrm{~A}$ & 10400 & $18,2 \%$ & 1893 & $8,8 \%$ & 915 & $3,0 \%$ & $0,0 \%$ \\
\hline $60 \mathrm{~B}$ & 8000 & $22,0 \%$ & 1760 & $7,0 \%$ & 560 & $0,0 \%$ & $20,0 \%$ \\
\hline 37 & 9600 & $35,5 \%$ & 3408 & $10,0 \%$ & 960 & $0,0 \%$ & $0,0 \%$ \\
\hline 27 & 16850 & $5,8 \%$ & 977 & $6,4 \%$ & 1078 & $0,0 \%$ & $0,0 \%$ \\
\hline 59 & 15400 & $15,0 \%$ & 2310 & $14,0 \%$ & 2156 & $2,0 \%$ & $0,0 \%$ \\
\hline
\end{tabular}


ANEXO 3 - Descrição do imunofenótipo dos linfócitos do sangue periférico para o grupo de pacientes denominado "REATIVO"

\begin{tabular}{|c|c|c|c|c|c|c|c|c|c|c|c|c|c|}
\hline N. & NK & CD19 & $\begin{array}{l}\text { CD3 } \\
\text { total }\end{array}$ & $\begin{array}{l}\text { CD3/ } \\
\text { CD2 }\end{array}$ & $\begin{array}{l}\text { CD3/ } \\
\text { CD5 }\end{array}$ & $\begin{array}{l}\text { CD3/ } \\
\text { CD7 }\end{array}$ & $\begin{array}{c}\text { CD3/ } \\
\text { CD4 }\end{array}$ & $\begin{array}{r}\text { CD3/ } \\
\text { CD8 }\end{array}$ & $\begin{array}{r}\mathrm{CD} 3 / \\
\mathrm{TCR} \alpha \beta \\
\end{array}$ & $\begin{array}{r}\text { CD3/ } \\
\text { TCRYס }\end{array}$ & CD4:8 & $\begin{array}{l}\text { CD3/ } \\
\text { CD25 }\end{array}$ & $\begin{array}{l}\text { CD3/ } \\
\text { CLA }\end{array}$ \\
\hline 9 & $2,0 \%$ & $10,0 \%$ & $82,0 \%$ & $82,0 \%$ & $79,0 \%$ & $74,0 \%$ & $64,0 \%$ & $12,0 \%$ & $80,0 \%$ & $3,0 \%$ & 5,3 & $23,0 \%$ & $2,0 \%$ \\
\hline 12 & $2,0 \%$ & $9,0 \%$ & $78,0 \%$ & $76,0 \%$ & $74,0 \%$ & $65,0 \%$ & $52,0 \%$ & $26,0 \%$ & $74,0 \%$ & $1,0 \%$ & 2 & $23,0 \%$ & $6,0 \%$ \\
\hline 50 & $3,0 \%$ & $10,0 \%$ & $86,0 \%$ & - & - & - & $65,0 \%$ & $20,0 \%$ & - & - & 3,3 & - & - \\
\hline 66 & $3,0 \%$ & $11,0 \%$ & $82,0 \%$ & $81,0 \%$ & $75,0 \%$ & $70,0 \%$ & $58,0 \%$ & $25,0 \%$ & $79,0 \%$ & $2,0 \%$ & 2,3 & $18,0 \%$ & $2,0 \%$ \\
\hline 67 & $5,0 \%$ & $9,0 \%$ & $80,0 \%$ & $79,0 \%$ & $79,0 \%$ & $78,0 \%$ & $51,0 \%$ & $27,0 \%$ & $72,0 \%$ & - & 1,9 & $14,0 \%$ & $4,0 \%$ \\
\hline 70 & $4,0 \%$ & $6,0 \%$ & $76,0 \%$ & $76,0 \%$ & $75,0 \%$ & $75,0 \%$ & $55,0 \%$ & $22,0 \%$ & $79,0 \%$ & $4,0 \%$ & 2,5 & $32,0 \%$ & $0,0 \%$ \\
\hline 5 & $6,0 \%$ & $16,0 \%$ & $68,0 \%$ & $63,0 \%$ & $61,0 \%$ & $56,0 \%$ & $30,0 \%$ & $27,0 \%$ & $63,0 \%$ & $1,0 \%$ & 1,1 & $19,0 \%$ & $8,0 \%$ \\
\hline 54 & $3,0 \%$ & $8.5 \%$ & $85,0 \%$ & $85,0 \%$ & $83,0 \%$ & $73,0 \%$ & $65,0 \%$ & $18,0 \%$ & $79,5 \%$ & $2,0 \%$ & 3,6 & $12,0 \%$ & $3,0 \%$ \\
\hline 69 & $6,0 \%$ & $4,0 \%$ & $77,0 \%$ & $75,0 \%$ & $66,0 \%$ & $55,0 \%$ & $60,0 \%$ & $17,0 \%$ & $76,0 \%$ & $2,0 \%$ & 3,5 & $24,0 \%$ & $2,0 \%$ \\
\hline 71 & $5,0 \%$ & $6,0 \%$ & $82,0 \%$ & $80,0 \%$ & $73,0 \%$ & $43,0 \%$ & $43,0 \%$ & $36,0 \%$ & $75,0 \%$ & $2,5 \%$ & 1,2 & $13,0 \%$ & $3,5 \%$ \\
\hline 2 & $5,0 \%$ & $14,0 \%$ & $72,0 \%$ & $72,0 \%$ & $69,0 \%$ & $70,0 \%$ & $41,0 \%$ & $31,0 \%$ & $66,0 \%$ & $10,0 \%$ & 1,3 & $11,0 \%$ & $1,0 \%$ \\
\hline 20 & $19,0 \%$ & $12,0 \%$ & $63,0 \%$ & $63,0 \%$ & $60,0 \%$ & $54,5 \%$ & $32,0 \%$ & $28,0 \%$ & $55,0 \%$ & $5,0 \%$ & 1,1 & $8,0 \%$ & $7,0 \%$ \\
\hline 11 & $20,0 \%$ & $2.5 \%$ & $72,0 \%$ & $69,0 \%$ & $64,0 \%$ & $30,0 \%$ & $47,0 \%$ & $23,0 \%$ & $69,0 \%$ & $2,0 \%$ & 2 & $10,0 \%$ & $3,0 \%$ \\
\hline $13 \mathrm{~A}$ & $13,0 \%$ & $9,0 \%$ & $72,0 \%$ & $70,0 \%$ & $66,0 \%$ & $66,0 \%$ & $34,0 \%$ & $37,0 \%$ & $78,0 \%$ & $1,0 \%$ & 0,9 & $12,0 \%$ & $1,0 \%$ \\
\hline $13 \mathrm{~B}$ & $11,0 \%$ & $14,0 \%$ & $75,0 \%$ & $72,0 \%$ & $70,0 \%$ & $63,0 \%$ & $32,0 \%$ & $40,0 \%$ & $73,0 \%$ & $2,0 \%$ & 0,8 & $13,0 \%$ & $1,0 \%$ \\
\hline 17 & $11,0 \%$ & $7,0 \%$ & $80,0 \%$ & $80,0 \%$ & $79,0 \%$ & $70,0 \%$ & $48,0 \%$ & $31,0 \%$ & $78,0 \%$ & $0,0 \%$ & 1,5 & $39,0 \%$ & - \\
\hline 34 & $7,0 \%$ & $10,0 \%$ & $77,0 \%$ & $75,0 \%$ & $77,0 \%$ & $65,0 \%$ & $35,0 \%$ & $42,0 \%$ & $77,0 \%$ & $3.5 \%$ & 0,8 & $15,0 \%$ & $8,0 \%$ \\
\hline 44 & $9,0 \%$ & $11,0 \%$ & $79,0 \%$ & $75,0 \%$ & $76,0 \%$ & $64,0 \%$ & $50,0 \%$ & $27,0 \%$ & $74,0 \%$ & $4,0 \%$ & 1,8 & $16,0 \%$ & $7,0 \%$ \\
\hline 65 & $13,0 \%$ & $15,0 \%$ & $71,0 \%$ & $72,0 \%$ & $64,0 \%$ & $70,0 \%$ & $40,0 \%$ & $29,0 \%$ & $68,0 \%$ & $1,0 \%$ & 1,3 & $16,0 \%$ & - \\
\hline $1 \mathrm{~A}$ & $20,0 \%$ & $20,0 \%$ & $57,0 \%$ & $57,0 \%$ & $56,0 \%$ & - & $31,0 \%$ & $22,0 \%$ & - & $4,0 \%$ & 1,4 & $0,0 \%$ & - \\
\hline $1 \mathrm{~B}$ & $13,0 \%$ & $6,0 \%$ & $79,0 \%$ & $79,0 \%$ & $73,0 \%$ & $58,0 \%$ & $47,0 \%$ & $30,0 \%$ & $73,0 \%$ & $1,0 \%$ & 1,5 & $14,0 \%$ & $25,0 \%$ \\
\hline 28 & $18,0 \%$ & $7,0 \%$ & $68,5 \%$ & $68,0 \%$ & $66,0 \%$ & $49,0 \%$ & $53,0 \%$ & $12,0 \%$ & $60,0 \%$ & $2,0 \%$ & 4,4 & $4,0 \%$ & $12,0 \%$ \\
\hline $60 \mathrm{~A}$ & $1,0 \%$ & $13,0 \%$ & $82,0 \%$ & $79,0 \%$ & $76,0 \%$ & $62,0 \%$ & $53,0 \%$ & $29,0 \%$ & $71,0 \%$ & $6,0 \%$ & 1,8 & $27,0 \%$ & $10,0 \%$ \\
\hline $60 \mathrm{~B}$ & $6,0 \%$ & $4,0 \%$ & $86,0 \%$ & $86,0 \%$ & $84,0 \%$ & $53,0 \%$ & $55,0 \%$ & $23,0 \%$ & $77,0 \%$ & $11,0 \%$ & 2,4 & $30,0 \%$ & $13,0 \%$ \\
\hline 37 & $9,0 \%$ & $4,0 \%$ & $84,0 \%$ & $84,0 \%$ & $84,0 \%$ & $77,0 \%$ & $59,0 \%$ & $24,0 \%$ & $80,0 \%$ & $4,0 \%$ & 2,5 & $25,0 \%$ & $1,0 \%$ \\
\hline 27 & $13,0 \%$ & $18,0 \%$ & $59,0 \%$ & $59,0 \%$ & $59,0 \%$ & $50,0 \%$ & $24,0 \%$ & - & $47,0 \%$ & $1,0 \%$ & 1,0 & - & - \\
\hline 59 & $4,0 \%$ & $21,0 \%$ & $76,0 \%$ & $69,0 \%$ & $68,0 \%$ & $35,0 \%$ & $49,0 \%$ & $27,0 \%$ & $59,0 \%$ & $1,0 \%$ & 1,8 & $3,0 \%$ & $1,0 \%$ \\
\hline
\end{tabular}


ANEXO 4 - Descrição dos exames histopatológicos para o grupo de pacientes denominado "REATIVO"

\begin{tabular}{|c|c|c|c|}
\hline N. & DATA & Local: Descrição histopatológica & Diagnóstico \\
\hline 9 & $30 / 01 / 2006$ & Não realizado & - \\
\hline 12 & $13 / 05 / 2005$ & Não realizado & - \\
\hline 50 & $24 / 04 / 2006$ & Não realizado & - \\
\hline 66 & $27 / 04 / 2006$ & Não realizado & - \\
\hline 67 & $02 / 03 / 2004$ & $\begin{array}{l}\text { MSE: Dermatite psoriasiforme espongiótica } \\
\text { com áreas de ulceração }\end{array}$ & SD: Dermatite atópica \\
\hline 70 & 08/08/1997 & MSD: Dermatite espongiótica discreta & - \\
\hline & 08/08/1997 & MSE: Dermatite psoriasiforme e espongiótica subaguda & - \\
\hline & 08/08/1997 & DOR: Dermatite psoriasiforme e espongiótica subaguda & - \\
\hline $5 \mathrm{~A}$ & $31 / 01 / 2002$ & FAC: Dermatite psoriasiforme e espongiótica & SD: Reação de hipersensibilidade \\
\hline & $31 / 01 / 2002$ & DOR: Dermatite psoriasiforme e espongiótica & SD: Reação de hipersensibilidade \\
\hline & $31 / 01 / 2002$ & MSD: Dermatite psoriasiforme e espongiótica & SD: Reação de hipersensibilidade \\
\hline $5 \mathrm{~B}$ & $14 / 02 / 2002$ & MSE: Dermatite psoriasiforme e espongiótica & SD: Reação de hipersensibilidade \\
\hline & $14 / 02 / 2002$ & FAC: Dermatite psoriasiforme e espongiótica & SD: Reação de hipersensibilidade \\
\hline & $14 / 02 / 2002$ & TOR: Dermatite psoriasiforme e espongiótica & SD: Reação de hipersensibilidade \\
\hline $5 \mathrm{C}$ & $20 / 11 / 2003$ & LOM: Dermatite psoriasiforme e espongiótica & - \\
\hline & $20 / 11 / 2003$ & MIE: Dermatite psoriasiforme e espongiótica & - \\
\hline & $20 / 11 / 2003$ & PES: Dermatite psoriasiforme e espongiótica & - \\
\hline 54 & $21 / 03 / 2002$ & DOR: Dermatite psoriasiforme & - \\
\hline & $21 / 03 / 2002$ & MSD: Dermatite psoriasiforme & - \\
\hline & $21 / 03 / 2002$ & TOR: Dermatite psoriasiforme & - \\
\hline
\end{tabular}

continua 
ANEXO 4 - Continuação: Descrição dos exames histopatológicos para o grupo de pacientes denominado "REATIVO"

\begin{tabular}{|c|c|c|c|}
\hline $\mathbf{N}$. & DATA & Local: Descrição histopatológica & Diagnóstico \\
\hline $69 \mathrm{~A}$ & $30 / 01 / 2003$ & MSD: Dermatite psoriasiforme e espongióticae & - \\
\hline & $30 / 01 / 2003$ & MSD: Dermatite psoriasiforme e espongiótica & - \\
\hline $69 \mathrm{~B}$ & $04 / 02 / 2003$ & MID: Dermatite psoriasiforme e espongiótica & - \\
\hline $69 \mathrm{C}$ & $03 / 04 / 2003$ & PAL: Dermatite psoriasiforme e espongiótica & - \\
\hline 71 & $21 / 02 / 2002$ & DOR: Dermatite espongiótica & SD: Reação de hipersensibilidade \\
\hline & $21 / 02 / 2002$ & TRO: Dermatite espongiótica & SD: Reação de hipersensibilidade \\
\hline & $21 / 02 / 2002$ & MID: Dermatite espongiótica & SD: Reação de hipersensibilidade \\
\hline 2 & $19 / 02 / 2004$ & ABD: Dermatite psoriasiforme & PD: PRP \\
\hline & $19 / 02 / 2004$ & ABD: & SD: Psoríase \\
\hline 20 & $13 / 03 / 2002$ & TOR: Dermatite psoriasiforme & CC: PRP \\
\hline & $13 / 03 / 2002$ & MSD: Dermatite psoriasiforme & CC: PRP \\
\hline $11 \mathrm{~A}$ & $17 / 01 / 1996$ & DOR: & DX: Psoríase \\
\hline & $17 / 01 / 1996$ & TOR: & DX: Psoríase \\
\hline & 17/01/1996 & MIE: Dermatite psoriasiforme & \\
\hline $11 \mathrm{~B}$ & $12 / 09 / 2002$ & MSE: & DX: Psoríase \\
\hline $13 \mathrm{~A}$ & $20 / 06 / 2000$ & QUA: & DX: Psoríase \\
\hline & $20 / 06 / 2000$ & MSE: & DX: Psoríase \\
\hline & $20 / 06 / 2000$ & MID: & DX: Psoríase \\
\hline $13 \mathrm{~B}$ & 02/09/2004 & PES: Dermatite psoriasiforme & - \\
\hline 17 & $21 / 02 / 2006$ & Não realizado & - \\
\hline
\end{tabular}

continua 


\section{ANEXO 4 - Continuação: Descrição dos exames histopatológicos para o grupo de pacientes denominado "REATIVO"}

\begin{tabular}{|c|c|c|c|}
\hline N. & DATA & Local: Descrição histopatológica & Diagnóstico \\
\hline \multirow[t]{3}{*}{34} & $10 / 12 / 2002$ & MSD: Dermatite psoriasiforme & - \\
\hline & $12 / 12 / 2002$ & MID: Dermatite psoriasiforme & - \\
\hline & $12 / 12 / 2002$ & MIE: Dermatite psoriasiforme & - \\
\hline 44 & $29 / 01 / 2002$ & MID: & CC: Psoríase \\
\hline \multirow[t]{3}{*}{65} & $02 / 03 / 2005$ & LOB: & DX: Psoríase \\
\hline & $02 / 03 / 2005$ & MIE: & DX: Psoríase \\
\hline & $02 / 03 / 2005$ & MSD: & DX: Psoríase \\
\hline \multirow[t]{3}{*}{$1 \mathrm{~A}$} & $06 / 02 / 2001$ & $\begin{array}{l}\text { MSD: Dermatite liquenóide com infiltrado linfocitário } \\
\text { com leve atipia e epidermotropismo. }\end{array}$ & PD: 1.Farmacodermia, 2. MF/SS \\
\hline & $06 / 02 / 2001$ & $\begin{array}{l}\text { TRO: Dermatite liquenóide com infiltrado linfocitário } \\
\text { Com leve atipia e epidermotropismo }\end{array}$ & PD: 1.Farmacodermia, 2. MF/SS \\
\hline & $06 / 02 / 2001$ & $\begin{array}{l}\text { TRO: Dermatite liquenóide com infiltrado linfocitário } \\
\text { Com leve atipia e epidermotropismo }\end{array}$ & PD: 1.Farmacodermia, 2. MF/SS \\
\hline $1 \mathrm{~B}$ & $31 / 10 / 2001$ & $\begin{array}{l}\text { DOR: Dermatite de interface liquenóide espongiótica } \\
\text { Com acentuado epidermotropismo }\end{array}$ & PD: MF \\
\hline \multirow[t]{2}{*}{$1 \mathrm{C}$} & $14 / 11 / 2001$ & MID: Dermatite liquenóide e perivascular & $\begin{array}{l}\text { PD: 1.Farmacodermia, } \\
\text { 2. Processo linfoproliferativo cutâneo neoplásico }\end{array}$ \\
\hline & $14 / 11 / 2001$ & MSD: Dermatite liquenóide e perivascular & $\begin{array}{l}\text { PD: 1.Farmacodermia, } \\
\text { 2. Processo linfoproliferativo cutâneo neoplásico }\end{array}$ \\
\hline 28 & $24 / 10 / 2001$ & Não relizado & - \\
\hline \multirow[t]{3}{*}{$60 \mathrm{~A}$} & $26 / 04 / 2002$ & $\begin{array}{l}\text { MSD: Dermatite psoriasiforme e espongiótica } \\
\text { perivascular superficial com raros eosinófilos }\end{array}$ & - \\
\hline & $26 / 04 / 2002$ & $\begin{array}{l}\text { MSE: Dermatite psoriasiforme e espongiótica } \\
\text { perivascular superficial com raros eosinófilos }\end{array}$ & - \\
\hline & $26 / 04 / 2002$ & $\begin{array}{l}\text { MSE: Dermatite psoriasiforme e espongiótica } \\
\text { perivascular superficial com eosinófilos }\end{array}$ & SD: Reação de hipersensibilidade \\
\hline \multirow[t]{2}{*}{$60 \mathrm{~B}$} & $04 / 06 / 2002$ & $\begin{array}{l}\text { MID: Dermatite psoriasiforme e espongiótica } \\
\text { perivascular superficial com eosinófilos }\end{array}$ & SD: Reação de hipersensibilidade \\
\hline & $04 / 06 / 2002$ & $\begin{array}{l}\text { DOR: Dermatite psoriasiforme e espongiótica } \\
\text { perivascular superficial com eosinófilos }\end{array}$ & SD: Reação de hipersensibilidade \\
\hline
\end{tabular}

\section{continua}


ANEXO 4 - Continuação: Descrição dos exames histopatológicos para o grupo de pacientes denominado "REATIVO"

\begin{tabular}{|c|c|c|c|}
\hline $\mathbf{N}$. & DATA & Local: Descrição histopatológica & Diagnóstico \\
\hline 37 & 03/03/2004 & DOR: Dermatite psoriasiforme e espongióticae & - \\
\hline & 03/03/2004 & MSD: Dermatite psoriasiforme & - \\
\hline & 03/03/2004 & DOR: Dermatite psoriasiforme e espongiótica & - \\
\hline 27 & $11 / 05 / 2005$ & DOR: Dermatite psoriasiforme e espongiótica com eosinófilos & PC: Reação de hipersensibilidade \\
\hline & $11 / 05 / 2005$ & ABD: Dermatite psoriasiforme e espongiótica com eosinófilos & PC: Reação de hipersensibilidade \\
\hline & $11 / 05 / 2005$ & MSD: Dermatite psoriasiforme e espongiótica com eosinófilos & PC: Reação de hipersensibilidade \\
\hline $59 \mathrm{~A}$ & $20 / 03 / 2002$ & DOR: Dermatite psoriasiforme e espongiótica & - \\
\hline & 20/03/2002 & MSE: Dermatite psoriasiforme e espongiótica & - \\
\hline & $20 / 03 / 2002$ & MIE: Dermatite psoriasiforme e espongiótica & - \\
\hline $59 \mathrm{~B}$ & 09/04/2004 & DOR: Dermatite psoriasiforme e espongiótica & - \\
\hline
\end{tabular}

MSE: membro superior esquerdo; MSD: membro superior direito; MIE: membro inferior esquerdo; MID: membro inferior direito; DOR: dorso; TOR: tórax; LOM: lombar; ABD: abdômen; QUA: quadril; FAC: face; PES: pescoço; PAL: região palmar; PLA: região plantar; OMB: ombro; FLA: flanco; XXX local não especificado; MSX: membro superior, lado não especificado; MIX: membro inferior, lado não especificado; CC: compatível com; DX; diagnóstico de; PD: possibilidade de; SD: sugestivo de; PC: pode corresponder 
ANEXO 5 - Descrição do grupo de pacientes denominado "MICOSE FUNGÓIDE/SÍNDROME DE SÉZARY" de acordo com a idade, seXo, cor, antecedentes pessoais (AP), uso de drogas, diagnóstico final, tempo de evolução em meses na ocasião da primeira avaliação (Tev), tempo de seguimento em meses (Tseg), tratamento e evolução na última observação ou óbito

\begin{tabular}{|c|c|c|c|c|c|c|c|c|c|c|c|}
\hline N. & Nome & Idade & Sexo & Cor & AP & Drogas & Diag. Final & Tev & Tseg & Tratamento & Evolução \\
\hline 3 & ASN & 60 & M & $\mathrm{Pa}$ & - & $\begin{array}{r}\text { PDN } \\
\text { Sulfoniluréia }\end{array}$ & MF eritrod. & 10 & 32 & $\begin{array}{l}\text { IFN \& PUVA } \\
\text { CLB \& PDN } \\
\text { Fludarabina }\end{array}$ & VSED \\
\hline 6 & BS & 50 & M & $\mathrm{Pa}$ & - & PDN & MF eritrod. & 24 & 13 & IFN \& PUVA & VCED \\
\hline 18 & FE & 81 & M & $\mathrm{N}$ & - & Furosemida & MF eritrod. & 2 & 30 & $\begin{array}{l}\text { CLB \& PDN } \\
\text { Talidomida }\end{array}$ & $\begin{array}{r}\text { MCED } \\
\text { Cirurgia }\end{array}$ \\
\hline 23 & HRS & 67 & M & $\mathrm{Pa}$ & - & - & MF eritrod. & 12 & 19 & - & $\begin{array}{l}\text { MCED } \\
\text { Sepse }\end{array}$ \\
\hline 35 & JBO & 59 & M & B & $\begin{array}{l}\text { Síndrome } \\
\text { de Gilbert }\end{array}$ & - & MF eritrod. & 60 & 65 & $\begin{array}{r}\text { CLB \& PDN } \\
\text { Corticoterapia } \\
\text { tópica }\end{array}$ & VCED \\
\hline 49 & MAVB & 45 & $\mathrm{~F}$ & $\mathrm{~Pa}$ & $\begin{array}{r}\text { HAS } \\
\text { Litíase } \\
\text { renal }\end{array}$ & Clortalidona & MF eritrod. & 24 & 21 & PUVA & VCED \\
\hline 61 & SB & 77 & M & $\mathrm{Pa}$ & $\begin{array}{r}\text { HAS } \\
\text { Arritmia }\end{array}$ & $\begin{array}{r}\text { Clortalidona } \\
\text { Captopril } \\
\text { Quinidina }\end{array}$ & MF eritrod. & 24 & 15 & $\begin{array}{r}\text { PUVA } \\
\text { Corticoterapia } \\
\text { tópica }\end{array}$ & VCED \\
\hline 29 & JAR & 54 & M & B & - & - & MF eritrod. & 24 & 7 & IFN \& PUVA & $\begin{array}{l}\text { MCED } \\
\text { Sepse }\end{array}$ \\
\hline 16 & FNS & 58 & M & B & - & - & S. de Sézary & 36 & 4 & - & $\begin{array}{l}\text { MCED } \\
\text { Sepse }\end{array}$ \\
\hline 25 & IRS & 85 & $\mathrm{~F}$ & $\mathrm{~Pa}$ & - & - & S. de Sézary & 3 & 1 & - & $\begin{array}{r}\text { MCED } \\
\text { ICC }\end{array}$ \\
\hline 41 & LMPT & 73 & $\mathrm{~F}$ & B & - & - & S. de Sézary & 3 & 17 & $\begin{array}{r}\text { CLB \& PDN } \\
\text { Corticoterapia } \\
\text { tópica }\end{array}$ & VCED \\
\hline 52 & MJSS & 43 & $\mathrm{~F}$ & $\mathrm{~N}$ & - & - & S. de Sézary & 84 & 52 & IFN \& PUVA & VCED \\
\hline 62 & SAO & 56 & M & $\mathrm{Pa}$ & $\begin{array}{r}\text { HAS } \\
\text { Asma }\end{array}$ & - & S. de Sézary & 4 & 22 & $\begin{array}{r}\text { IFN \& PUVA } \\
\text { CLB \& DEXA } \\
\text { Talidomida }\end{array}$ & $\begin{array}{r}\text { MCED } \\
\text { Causa? }\end{array}$ \\
\hline
\end{tabular}


ANEXO 6 - Descrição das variáveis hematológicas: leucócitos,

número relativo de linfócitos (LINF \%), número absoluto de

linfócitos (LINF ABS), número relativo de eosinófilos (EOS \%), número absoluto de eosinófilos (EOS ABS), percentual de células de Sézary (\% CS) e de linfócitos pleomórficos (\% LP) para o grupo de pacientes denominado "MICOSE FUNGÓIDE / SÍNDROME DE SÉZARY"

\begin{tabular}{|c|c|c|c|c|c|c|c|}
\hline $\mathrm{N}$. & LEUCÓCITOS & LINF \% & LINF ABS & EOS \% & EOS ABS & $\%$ CS & $\%$ LP \\
\hline $3 \mathrm{~A}$ & 13900 & $15,0 \%$ & 2085 & $18,7 \%$ & 2599 & $5,0 \%$ & $28,0 \%$ \\
\hline $3 B$ & 13400 & $35,1 \%$ & 4703 & $20,5 \%$ & 2747 & - & - \\
\hline 6 & 10290 & $45,0 \%$ & 4630 & $8,0 \%$ & 823 & - & - \\
\hline $18 \mathrm{~A}$ & - & - & - & - & - & $5,0 \%$ & $28,0 \%$ \\
\hline $18 \mathrm{~B}$ & 1780 & $4,0 \%$ & 71 & $1,0 \%$ & 18 & - & - \\
\hline $23 \mathrm{~A}$ & 8650 & $34,3 \%$ & 2967 & $6,0 \%$ & 519 & $3,0 \%$ & $64,0 \%$ \\
\hline $23 \mathrm{~B}$ & 11220 & $48,7 \%$ & 5464 & $7,6 \%$ & 853 & $6,0 \%$ & - \\
\hline $35 \mathrm{~A}$ & 4100 & $13,0 \%$ & 533 & $1,0 \%$ & 41 & - & - \\
\hline $35 \mathrm{~B}$ & 4710 & $17,8 \%$ & 838 & $1,6 \%$ & 75 & $1,0 \%$ & - \\
\hline 49 & 9510 & $33,0 \%$ & 2748 & $1,0 \%$ & 95 & - & - \\
\hline 61 & 9810 & $28,9 \%$ & 3237 & $9,9 \%$ & 971 & $2,0 \%$ & - \\
\hline 29 & 5100 & $26,1 \%$ & 1331 & $3,0 \%$ & 153 & - & $38,0 \%$ \\
\hline 16 & 92150 & $86,0 \%$ & 79249 & $0,0 \%$ & 0 & $29,0 \%$ & $51,0 \%$ \\
\hline 25 & 19030 & $15,0 \%$ & 2854 & $1,0 \%$ & 190 & $95,0 \%$ & $3,0 \%$ \\
\hline 41 & 8910 & $38,0 \%$ & 3386 & $3,0 \%$ & 267 & $26,0 \%$ & $58,0 \%$ \\
\hline 52 & 22400 & $33,3 \%$ & 7459 & $4,0 \%$ & 896 & $44,0 \%$ & $28,0 \%$ \\
\hline $62 \mathrm{~A}$ & 26600 & $41,0 \%$ & 10906 & $12,0 \%$ & 3192 & - & $10,0 \%$ \\
\hline $62 \mathrm{~B}$ & 30600 & $53,4 \%$ & 16340 & $2,9 \%$ & 474 & $10,0 \%$ & $41,0 \%$ \\
\hline
\end{tabular}

OBS: \%CS E \%LP OBTIDOS A PARTIR DA CONTAGEM EM 100 LEUCÓCITOS

caso 3 - presença de $2 \%$ de CS grandes

caso 16 - presença de $4 \%$ de CS grandes

caso 18 - presença de $2 \%$ de CS grandes

caso 25 - presença de $74 \%$ de CS grandes

caso 41 - presença de $4 \%$ de CS grandes

caso 52- presença de $9 \%$ de CS grandes 


\section{ANEXO 7 - Descrição do imunofenótipo dos linfócitos do sangue periférico para o grupo de pacientes denominado "MICOSE FUNGÓIDE / SÍNDROME DE SÉZARY"}

\begin{tabular}{|c|c|c|c|c|c|c|c|c|c|c|c|c|c|}
\hline N. & CD19 & NK & $\begin{array}{l}\text { CD3 } \\
\text { total }\end{array}$ & $\begin{array}{l}\text { CD3/ } \\
\text { CD2 }\end{array}$ & $\begin{array}{l}\text { CD3/ } \\
\text { CD5 }\end{array}$ & $\begin{array}{l}\text { CD3/ } \\
\text { CD7 }\end{array}$ & $\begin{array}{l}\text { CD3/ } \\
\text { CD4 }\end{array}$ & $\begin{array}{c}\text { CD3/ } \\
\text { CD8 }\end{array}$ & $\begin{array}{r}\text { CD3/ } \\
\text { TCR } \alpha \beta\end{array}$ & $\begin{array}{r}\text { CD3/ } \\
\text { TCRYठ }\end{array}$ & CD4:8 & $\begin{array}{l}\text { CD3/ } \\
\text { CD25 }\end{array}$ & $\begin{array}{l}\text { CD3/ } \\
\text { CLA }\end{array}$ \\
\hline $3 \mathrm{~A}$ & $3,0 \%$ & $12,5 \%$ & $81,0 \%$ & $79,0 \%$ & $78,0 \%$ & $50,0 \%$ & $63,0 \%$ & $19,0 \%$ & $75,0 \%$ & $2,0 \%$ & 3,3 & $43,0 \%$ & $29,0 \%$ \\
\hline $3 \mathrm{~B}$ & - & - & - & - & - & - & - & - & - & - & 18,9 & - & - \\
\hline $6 \mathrm{~A}$ & $5,0 \%$ & $8,0 \%$ & $87,0 \%$ & $87,0 \%$ & $82,0 \%$ & $75,0 \%$ & $67,5 \%$ & $16,0 \%$ & $85,0 \%$ & $1,5 \%$ & 4,2 & $35,0 \%$ & $10,0 \%$ \\
\hline $6 \mathrm{~B}$ & $3,0 \%$ & $8,0 \%$ & $85,0 \%$ & - & - & - & - & - & - & - & - & - & - \\
\hline $18 \mathrm{~A}$ & $9,0 \%$ & $26,0 \%$ & $59,0 \%$ & $61,0 \%$ & $62,0 \%$ & $29,0 \%$ & $43,0 \%$ & $13,0 \%$ & $50,0 \%$ & $1,0 \%$ & 3,3 & $6,0 \%$ & $9,0 \%$ \\
\hline $18 \mathrm{~B}$ & $7,0 \%$ & $4,0 \%$ & $83,0 \%$ & $82,0 \%$ & $81,0 \%$ & $67,0 \%$ & $56,0 \%$ & $26,5 \%$ & $76,0 \%$ & $4,0 \%$ & 2,1 & $30,0 \%$ & $1,0 \%$ \\
\hline $23 \mathrm{~A}$ & $16,0 \%$ & $11,0 \%$ & $88,0 \%$ & $87,0 \%$ & $86,0 \%$ & $45,0 \%$ & $77,0 \%$ & $11,0 \%$ & $88,0 \%$ & $0,0 \%$ & 7 & $19,0 \%$ & $3,0 \%$ \\
\hline $23 \mathrm{~B}$ & $3,0 \%$ & $2,0 \%$ & $86,0 \%$ & $86,0 \%$ & $76,0 \%$ & $24,0 \%$ & $75,0 \%$ & $9,0 \%$ & $83,0 \%$ & $1,0 \%$ & 8,3 & $17,0 \%$ & $3,0 \%$ \\
\hline $35 \mathrm{~A}$ & $7,5 \%$ & $9,0 \%$ & - & $75,0 \%$ & $70,0 \%$ & $63,0 \%$ & $37,0 \%$ & $42,0 \%$ & $72,0 \%$ & $4,0 \%$ & 0,9 & $1,5 \%$ & - \\
\hline $35 \mathrm{~B}$ & $22,0 \%$ & $5,0 \%$ & $70,0 \%$ & $70,0 \%$ & $70,0 \%$ & $64,0 \%$ & $32,0 \%$ & $42,0 \%$ & $69,0 \%$ & $2,0 \%$ & 0,8 & $25,0 \%$ & $3,0 \%$ \\
\hline 49 & $13,0 \%$ & $6,0 \%$ & $76,0 \%$ & $75,0 \%$ & $76,0 \%$ & $60,0 \%$ & $36,0 \%$ & $34,0 \%$ & $68,0 \%$ & $7,0 \%$ & 1,0 & $21,0 \%$ & $8,0 \%$ \\
\hline 61 & $18,0 \%$ & $12,0 \%$ & $62,0 \%$ & $57,0 \%$ & $57,0 \%$ & $46,0 \%$ & $45,0 \%$ & $17,0 \%$ & $59,0 \%$ & $2,0 \%$ & 2,6 & $32,0 \%$ & - \\
\hline 29 & $1,0 \%$ & $2,0 \%$ & $89,0 \%$ & $89,0 \%$ & $83,0 \%$ & $87,0 \%$ & $58,0 \%$ & $30,0 \%$ & $83,0 \%$ & $5,0 \%$ & 1,6 & $22,0 \%$ & $2,0 \%$ \\
\hline 16 & $0,0 \%$ & $1,0 \%$ & $98,0 \%$ & $98,0 \%$ & $99,0 \%$ & $3,0 \%$ & $86,0 \%$ & $2,0 \%$ & $98,0 \%$ & $1,0 \%$ & 43 & $48,0 \%$ & $9,0 \%$ \\
\hline 25 & $31,5 \%$ & $6,0 \%$ & $94,0 \%$ & $12,0 \%$ & $94,0 \%$ & $31,0 \%$ & $10,0 \%$ & $6,0 \%$ & $2,0 \%$ & $0,0 \%$ & 1,7 & $33,0 \%$ & $0,0 \%$ \\
\hline 41 & $5,0 \%$ & - & $86,0 \%$ & $86,0 \%$ & $85,0 \%$ & $22,0 \%$ & $13,0 \%$ & $7,0 \%$ & $84,0 \%$ & $1,0 \%$ & 1,8 & $22,0 \%$ & $2,0 \%$ \\
\hline 52 & $1,4 \%$ & $0,4 \%$ & $96,0 \%$ & $52,0 \%$ & $96,0 \%$ & $84,5 \%$ & $78,0 \%$ & $16,0 \%$ & $94,0 \%$ & $2,0 \%$ & 4,9 & $7,0 \%$ & $26,0 \%$ \\
\hline $62 \mathrm{~A}$ & $19,0 \%$ & $17,0 \%$ & $53,0 \%$ & $53,0 \%$ & $52,0 \%$ & $23,5 \%$ & $38,0 \%$ & $14,0 \%$ & $53,0 \%$ & $1,0 \%$ & 2,7 & $11,0 \%$ & $3,0 \%$ \\
\hline $62 \mathrm{~B}$ & $4,0 \%$ & $1,0 \%$ & $93,0 \%$ & $86,0 \%$ & $90,0 \%$ & $6,0 \%$ & $90,0 \%$ & $2,0 \%$ & $87,0 \%$ & $0,0 \%$ & 45 & $16,0 \%$ & $2,0 \%$ \\
\hline
\end{tabular}

caso 3(B) - aumento da relação CD4:CD8 $=18,9$

caso 16 - expansão de CD4 e aumento da relação $\operatorname{CD4}: \operatorname{CD} 8=43$

caso 25 - três populações de células; perda de CD4 e de TCRaß

caso 41 - perda de CD4

caso 52 - perda de CD2

caso 62(B) - expansão de CD4 e aumento da relação CD4:CD8 = 45

cor vermelha: valores muito abaixo da normalidade, conforme valores estabelecidos por grupo controle normal (ANEXO 15)

cor azul: valores muito acima da normalidade, conforme valores estabelecidos por grupo controle normal (ANEXO 15) 
ANEXO 8 - Descrição dos exames histopatológicos para o grupo de pacientes denominado "MICOSE FUNGÓIDE / SÍNDROME DE SÉZARY"

\begin{tabular}{|c|c|c|c|}
\hline $\mathbf{N}$. & DATA & Local: Descrição histopatológica & Diagnóstico \\
\hline \multirow[t]{3}{*}{$3 \mathrm{~A}$} & $11 / 01 / 2001$ & MSD: & SD: Linfoma angiocêntrico \\
\hline & $11 / 01 / 2001$ & DOR: & SD: Linfoma angiocêntrico \\
\hline & $11 / 01 / 2001$ & MIX: & SD: Linfoma angiocêntrico \\
\hline $3 B$ & $29 / 01 / 2001$ & DOR: & DX: Linfoma anfiocêntrico \\
\hline \multirow[t]{3}{*}{6} & $06 / 02 / 2004$ & $\begin{array}{l}\text { MSD: Dermatite psoriasiforme com espongiose } \\
\text { e epidermotropismo }\end{array}$ & SD: Micose fungóide \\
\hline & $06 / 02 / 2004$ & $\begin{array}{l}\text { DOR: Dermatite psoriasiforme com espongiose } \\
\text { e epidermotropismo }\end{array}$ & SD: Micose fungóide \\
\hline & $06 / 02 / 2004$ & $\begin{array}{l}\text { MID: Dermatite psoriasiforme com espongiose } \\
\text { e epidermotropismo }\end{array}$ & SD: Micose fungóide \\
\hline \multirow[t]{2}{*}{18} & $17 / 05 / 2002$ & TOR: & CC: Micose fungóide / síndrome de Sézary \\
\hline & $17 / 05 / 2002$ & TOR: & CC: Micose fungóide / síndrome de Sézary \\
\hline \multirow[t]{3}{*}{$23 \mathrm{~A}$} & 08/10/2004 & MSD: Dermatite psoriasiforme & - \\
\hline & 08/10/2004 & ABD: Dermatite psoriasiforme & - \\
\hline & $08 / 10 / 2004$ & MID: Dermatite psoriasiforme & - \\
\hline $23 \mathrm{~B}$ & $18 / 10 / 2004$ & FAC: Dermatite psoriasiforme com epidermotropismo & - \\
\hline \multirow[t]{2}{*}{35} & $27 / 01 / 2000$ & DOR: Processo linfoproliferativo com vasculite & PD: Papulose linfomatóide \\
\hline & $27 / 07 / 2001$ & FAC: & DX: Micose fungóide \\
\hline \multirow[t]{3}{*}{49} & $24 / 06 / 2003$ & MSX: & DX: Micose fungóide \\
\hline & $24 / 06 / 2003$ & FLA: & DX: Micose fungóide \\
\hline & $24 / 06 / 2003$ & DOR: & DX: Micose fungóide \\
\hline \multirow[t]{3}{*}{61} & $22 / 12 / 2004$ & DOR: & CC: Micose fungóide \\
\hline & $22 / 12 / 2004$ & MSX: & CC: Micose fungóide \\
\hline & $22 / 12 / 2004$ & ABD: & CC: Micose fungóide \\
\hline
\end{tabular}

\section{continua}




\section{ANEXO 8 - Continuação: Descrição dos exames histopatológicos para o grupo de pacientes denominado "MICOSE FUNGÓIDE / SíNDROME DE SÉZARY"}

\begin{tabular}{|c|c|c|c|}
\hline N. & DATA & Local: Descrição histopatológica & Diagnóstico \\
\hline \multirow[t]{3}{*}{16} & $18 / 10 / 2005$ & MSE: & PD: Processo linfomatoso \\
\hline & $18 / 10 / 2005$ & DOR: & PD: Processo linfomatoso \\
\hline & $18 / 10 / 2005$ & OMB: & PD: Processo linfomatoso \\
\hline 25 & $10 / 08 / 2004$ & XXX: Micose fungóide & - \\
\hline 29 & $14 / 09 / 2004$ & $X X X:$ & DX: Micose fungóide \\
\hline 41 & $13 / 08 / 2004$ & $X X X:$ & PD: Micose fungóide \\
\hline \multirow[t]{3}{*}{52} & $19 / 07 / 2001$ & FLA: & DX: Micose fungóide \\
\hline & $19 / 07 / 2001$ & TOR: & DX: Micose fungóide \\
\hline & $19 / 07 / 2001$ & MID: & DX: Micose fungóide \\
\hline \multirow[t]{3}{*}{$62 \mathrm{~A}$} & $22 / 08 / 2001$ & MSD: Dermatite psoriasiforme e espongiótica & - \\
\hline & $22 / 08 / 2001$ & ABD: Dermatite psoriasiforme e espongiótica & - \\
\hline & $22 / 08 / 2001$ & DOR: Dermatite psoriasiforme e espongiótica & - \\
\hline \multirow[t]{3}{*}{$62 \mathrm{~B}$} & $18 / 04 / 2002$ & ABD: Dermatite psoriasiforme e espongiótica & - \\
\hline & $18 / 04 / 2002$ & DOR: Dermatite psoriasiforme e espongiótica & - \\
\hline & $18 / 04 / 2002$ & MSD: Dermatite psoriasiforme e espongiótica & - \\
\hline
\end{tabular}

MSE: membro superior esquerdo; MSD: membro superior direito; MIE: membro inferior esquerdo; MID: membro inferior direito; DOR: dorso; TOR: tórax; LOM: lombar; ABD: abdômen; QUA: quadril; FAC: face; PES: pescoço; PAL: região palmar; PLA: região plantar; OMB: ombro; FLA: flanco; XXX local não especificado; MSX: membro superior, lado não especificado; MIX: membro inferior, lado não especificado; CC: compatível com; DX; diagnóstico de; PD: possibilidade de; SD: sugestivo de; PC: pode corresponder 
ANEXO 9 - Descrição das variáveis hematológicas: número relativo de linfócitos (LINF \%), número absoluto de linfócitos (LINF ABS), número relativo de eosinófilos (EOS \%), número absoluto de eosinófilos (EOS ABS), percentual de células de Sézary (\% CS) e de linfócitos pleomórficos (\% LP) para o grupo NORMAL

\begin{tabular}{|c|c|c|c|c|c|c|c|c|}
\hline $\mathrm{N}$. & SEXO & IDADE & \%LINF & LINF ABS & $\%$ EOS & EOS ABS & $\% \mathrm{CS}$ & \%LP \\
\hline 1 & $M$ & 35 & 25,0 & 1530 & 6,8 & 420 & 7,5 & 7,5 \\
\hline 2 & $\mathrm{~F}$ & 25 & 32,1 & 2930 & 0,6 & 50 & 2,5 & 4,5 \\
\hline 3 & $\mathrm{~F}$ & 24 & 33,4 & 1690 & 2,2 & 110 & 3,5 & 2,5 \\
\hline 4 & M & 19 & 19,5 & 1220 & 2,2 & 140 & 1 & 6 \\
\hline 5 & M & 29 & 20,2 & 1730 & 2,1 & 180 & 6,5 & 11,5 \\
\hline 6 & M & 22 & 19,1 & 740 & 1,5 & 60 & 2 & 6 \\
\hline 7 & M & 25 & 22,0 & 1430 & 1,4 & 90 & 3 & 7,5 \\
\hline 8 & M & 50 & 34,5 & 1730 & 1,4 & 70 & 0 & 3,5 \\
\hline 9 & $\mathrm{~F}$ & 40 & 28,5 & 1410 & 1,6 & 80 & 2,5 & 5 \\
\hline 10 & $M$ & 36 & 26,3 & 2180 & 2,9 & 240 & 4 & 3 \\
\hline 11 & $\mathrm{~F}$ & 48 & 23,5 & 1270 & 1,7 & 90 & 3,5 & 6 \\
\hline 12 & $\mathrm{~F}$ & 30 & 28,9 & 1800 & 4,7 & 290 & 3 & 6,5 \\
\hline 13 & $\mathrm{~F}$ & 45 & 25,4 & 1410 & 1,2 & 70 & 3 & 6,5 \\
\hline 14 & M & 30 & 25,0 & 1880 & 4,7 & 350 & 2,5 & 4 \\
\hline 15 & $\mathrm{~F}$ & 41 & 37,7 & 2090 & 1,7 & 90 & 9 & 9,5 \\
\hline 16 & M & 36 & 27,3 & 840 & 1,1 & 30 & 1,5 & 6,5 \\
\hline 17 & M & 23 & 25,3 & 1330 & 2,1 & 110 & 5,5 & 13 \\
\hline 18 & $\mathrm{~F}$ & 56 & 23,1 & 1240 & 3,3 & 180 & 5,5 & 7 \\
\hline 19 & $\mathrm{~F}$ & 32 & 23,6 & 2330 & 8,5 & 840 & 1,5 & 7 \\
\hline 20 & $\mathrm{~F}$ & 69 & 34,4 & 2260 & 0 & 0 & 5,5 & 13 \\
\hline 21 & $M$ & 86 & 20,0 & 1350 & 6 & 404 & 2 & 7,5 \\
\hline 22 & $\mathrm{~F}$ & 60 & 34,50 & 1720 & 3,2 & 0,16 & 0,5 & 3,5 \\
\hline 23 & $M$ & 70 & 26,20 & 1590 & 3,7 & 230 & 0,5 & 4,5 \\
\hline 24 & $\mathrm{~F}$ & 56 & 40,10 & 2500 & 5 & 300 & 0,5 & 3 \\
\hline 25 & $\mathrm{~F}$ & 56 & 32,20 & 2200 & 1,4 & 100 & 0 & 3 \\
\hline
\end{tabular}

OBS: \%CS E \%LP OBTIDOS A PARTIR DA CONTAGEM POR 100 LINFÓCITOS 
ANEXO 10 - Descrição do imunofenótipo dos linfócitos do sangue periférico para o grupo NORMAL

\begin{tabular}{|c|c|c|c|c|c|c|c|c|c|c|c|c|c|}
\hline N. & \%CD19 & $\%$ NK & $\begin{array}{r}\text { \%CD3 } \\
\text { Total } \\
\end{array}$ & $\begin{array}{r}\text { \%CD3/ } \\
\text { CD2 } \\
\end{array}$ & $\begin{array}{r}\text { \%CD3/ } \\
\text { CD5 } \\
\end{array}$ & $\begin{array}{r}\text { \%CD3/ } \\
\text { CD7 } \\
\end{array}$ & $\begin{array}{r}\text { \%CD3/ } \\
\text { CD4 } \\
\end{array}$ & $\begin{array}{r}\text { \%CD3/ } \\
\text { CD8 } \\
\end{array}$ & $\begin{array}{r}\% \text { CD3/ } \\
\text { TCR } \alpha \beta \\
\end{array}$ & $\begin{array}{r}\% \text { CD3/ } \\
\text { TCR Yठ } \\
\end{array}$ & $\begin{array}{r}\text { Relação } \\
\text { CD4:CD8 } \\
\end{array}$ & $\begin{array}{r}\text { \%CD3/ } \\
\text { CD25 } \\
\end{array}$ & $\begin{array}{r}\text { \%CD3/ } \\
\text { CLA }\end{array}$ \\
\hline 1 & 10 & 12 & 76 & 72 & 72 & 68 & 40 & 28 & 70 & 6 & 1,4 & 11,5 & 4,0 \\
\hline 2 & 17 & 4 & 78 & 75 & 74 & 67 & 50 & 26 & 66 & 2 & 1,9 & 9,5 & 1,5 \\
\hline 3 & 11 & 5 & 79 & 74 & 72 & 71 & 36 & 38 & 70 & 3 & 0,9 & 5 & 4,5 \\
\hline 4 & 6 & 12 & 76,5 & 69 & 73 & 65,5 & 43 & 30 & 70 & 3 & 1,4 & 12 & 3,0 \\
\hline 5 & 12 & 12 & 73 & 63 & 55,5 & 41 & 39 & 33 & 61 & 1,5 & 1,2 & 4 & 4,0 \\
\hline 6 & 13 & 10 & 60 & 54 & 58 & 52 & 41 & 18 & 54 & 1 & 2,3 & 13,5 & 6,0 \\
\hline 7 & 8 & 14 & 72,5 & 66 & 69,5 & 56 & 38 & 32,5 & 62 & 3 & 1,2 & 3,5 & 3,0 \\
\hline 8 & 10 & 7 & 75 & 62 & 61 & 49,5 & 52 & 22,5 & 65 & 2 & 2,3 & 7 & 6,0 \\
\hline 9 & 9 & 10,5 & 73,5 & 68 & 71 & 61 & 45 & 28,5 & 62 & 2 & 1,6 & 14 & 4,0 \\
\hline 10 & 12 & 5 & 79,5 & 70 & 75 & 66 & 49 & 29 & 70 & 3 & 1,7 & 5 & 2,0 \\
\hline 11 & 13 & 8 & 70 & 62 & 63 & 54 & 49 & 21 & 59 & 1 & 2,3 & 10 & 7,0 \\
\hline 12 & 13 & 4 & 78 & 72 & 75 & 52 & 57 & 19 & 73 & 1 & 3 & 4 & 1,0 \\
\hline 13 & 10 & 21,5 & 67 & 60,5 & 62 & 52,5 & 42 & 25 & 56 & 1 & 1,7 & 13 & 4,0 \\
\hline 14 & 7 & 16 & 73 & 73 & 71 & 63 & 46 & 26 & 64,5 & 1 & 1,8 & 12 & 6,0 \\
\hline 15 & 15 & 7 & 74 & 70 & 70 & 61,5 & 42 & 29 & 61 & 2 & 1,4 & 6 & 2,0 \\
\hline 16 & 4 & 12 & 68 & 66 & 41 & 60,5 & 50 & 16 & 67 & 2,5 & 3,1 & 5 & 6,0 \\
\hline 17 & 6 & 17 & 72 & 69 & 65,5 & 52 & 40 & 27 & 67 & 3 & 1,5 & 4 & 2,0 \\
\hline 18 & 3,5 & 7 & 88 & 85 & 83 & 56 & 63 & 18 & 79 & 8 & 3,5 & 5 & 3,0 \\
\hline 19 & 4 & 18 & 75 & 65 & 70 & 40 & 50 & 20 & 68,5 & 4,5 & 2,5 & 3 & 3,5 \\
\hline 20 & 14 & 13 & 69 & 67 & 67 & 64 & 50 & 17 & 66 & 2 & 2,9 & 18 & 15,5 \\
\hline 21 & 7 & 14 & 75 & 75 & 74 & 70 & 56 & 15 & 72,5 & 1 & 3,7 & 19 & 3,0 \\
\hline 22 & 9 & 7,5 & 80,5 & 80 & 78,5 & 73 & 45,5 & 35 & 73 & 5 & 1,3 & 16,5 & 3,00 \\
\hline 23 & 10 & 22 & 65 & 64 & 60 & 60 & 29 & 34 & 60 & 15 & 0,85 & 13 & 2,00 \\
\hline 24 & 19 & 11 & 65 & 65 & 63,5 & 61 & 47 & 17 & 62 & 1 & 2,8 & 25 & 3,00 \\
\hline 25 & 16 & - & 60 & 60 & 59 & 54,5 & 46 & 15 & 55 & 3 & 3,1 & 4 & 3 \\
\hline
\end{tabular}


ANEXO 11 - Grupos "REATIVo” versus "Micose FUnGóIDE /SÍNDROME DE SÉZARY”: médias e desvios-padrão das variáveis e significância do teste estatístico aplicado

\begin{tabular}{|c|c|c|c|c|c|}
\hline & $N$ & REATIVO & $N$ & MF/SS & $p$ \\
\hline LEUCÓCITOS(*) & 27 & $9802,96 \pm 2984,86$ & 15 & $17614,67 \pm 22228,31$ & 0,365 \\
\hline LINFÓCITOS(*) & 27 & $1828,81 \pm 714,90$ & 15 & $9504,07 \pm 19774,48$ & 0,018 \\
\hline EOSINÓFILOS(*) & 27 & $703,89 \pm 568,01$ & 15 & $897,07 \pm 1072,50$ & 0,646 \\
\hline$\%$ CS & 23 & $0,69 \pm 1,14$ & 14 & $7,50 \pm 12,98$ & 0,014 \\
\hline$\%$ LP & 21 & $2,28 \pm 4,76$ & 14 & $20,57 \pm 22,10$ & 0,021 \\
\hline CD3 TOTAL & 27 & $75,87 \pm 7,74$ & 15 & $80,47 \pm 13,68$ & 0,252 \\
\hline $\mathrm{CD} 3 / \mathrm{CD} 2$ & 26 & $74,08 \pm 7,76$ & 15 & $75,80 \pm 14,31$ & 0,671 \\
\hline $\mathrm{CD} 3 / \mathrm{CD} 5$ & 26 & $71,38 \pm 7,96$ & 15 & $77,20 \pm 13,42$ & 0,088 \\
\hline $\mathrm{CD} 3 / \mathrm{TCR} \alpha \beta\left(^{*}\right)$ & 25 & $71,30 \pm 8,65$ & 15 & $76,00 \pm 14,33$ & 0,203 \\
\hline $\mathrm{CD} 3 / \mathrm{CD} 7$ & 25 & $61,02 \pm 12,67$ & 15 & $48,47 \pm 26,60$ & 0,104 \\
\hline $\mathrm{CD} 3 / \mathrm{CD} 4$ & 27 & $47,15 \pm 11,71$ & 15 & $58,77 \pm 19,57$ & 0,049 \\
\hline RELAÇÃO CD4:CD8(*) & 27 & $2,04 \pm 1,13$ & 16 & $9,36 \pm 14,23$ & 0,015 \\
\hline $\mathrm{CD} 3 / \mathrm{CLA}\left({ }^{*}\right)$ & 22 & $5,48 \pm 5,79$ & 13 & $8,31 \pm 9,09$ & 0,287 \\
\hline $\mathrm{CD} 3 / \mathrm{CD} 25\left(^{*}\right)$ & 25 & $16,84 \pm 9,34$ & 15 & $22,23 \pm 13,50$ & 0,208 \\
\hline
\end{tabular}

$\mathrm{N}=$ número de exames computados na análise estatística para cada variável

$\left(^{*}\right)$ Váriáveis com suposição de normalidade não satisfeita analisadas por testes não paramétricos (Teste da mediana e Teste de Mann-Whitney) 
ANEXO 12 - Grupos “REATIVO" versus “CONTROLE”: médias e desvios-padrão das variáveis e significância do teste estatístico aplicado

\begin{tabular}{|c|c|c|c|c|c|}
\hline & $N$ & REATIVO & $N$ & CONTROLE & $p$ \\
\hline LEUCÓCITOS(*) & 27 & $9802,96 \pm 2984,86$ & 25 & $6200,00 \pm 1557,50$ & 0,000 \\
\hline LINFÓCITOS(*) & 27 & $1828,81 \pm 714,90$ & 25 & $1606,00 \pm 515,18$ & 0,527 \\
\hline EOSINÓFILOS(*) & 27 & $703,89 \pm 568,01$ & 25 & $180,97 \pm 182,54$ & 0,000 \\
\hline$\%$ CS & 23 & $0,69 \pm 1,14$ & - & - & - \\
\hline$\%$ LP & 21 & $2,28 \pm 4,76$ & - & - & - \\
\hline CD3 TOTAL & 27 & $75,87 \pm 7,74$ & 25 & $72,90 \pm 6,45$ & 0,141 \\
\hline $\mathrm{CD} 3 / \mathrm{CD} 2$ & 26 & $74,08 \pm 7,76$ & 25 & $68,26 \pm 6,73$ & 0,006 \\
\hline CD3/CD5 & 26 & $71,38 \pm 7,96$ & 25 & $67,34 \pm 8,77$ & 0,091 \\
\hline $\left.\mathrm{CD} 3 / \mathrm{TCR} \alpha \beta^{*}\right)$ & 25 & $71,30 \pm 8,65$ & 25 & $65,34 \pm 6,20$ & 0,002 \\
\hline $\mathrm{CD} 3 / \mathrm{CD} 7$ & 25 & $61,02 \pm 12,67$ & 25 & $58,84 \pm 8,62$ & 0,480 \\
\hline CD3/CD4 & 27 & $47,15 \pm 11,71$ & 25 & $45,82 \pm 7,27$ & 0,623 \\
\hline RELAÇÃO CD4:CD8(*) & 27 & $2,04 \pm 1,13$ & 25 & $2,05 \pm 0,83$ & 0,621 \\
\hline $\mathrm{CD} 3 / \mathrm{CLA}\left(^{*}\right)$ & 22 & $5,48 \pm 5,79$ & 25 & $4,08 \pm 2,86$ & 0,983 \\
\hline $\mathrm{CD} 3 / \mathrm{CD} 25\left(^{*}\right)$ & 25 & $16,84 \pm 9,34$ & 25 & $9,70 \pm 5,87$ & 0,005 \\
\hline
\end{tabular}

$\mathrm{N}=$ número de exames computados na análise estatística para cada variável

$\left(^{*}\right)$ Váriáveis com suposição de normalidade não satisfeita analisadas por testes não paramétricos (Teste da mediana e Teste de Mann-Whitney) 
ANEXO 13 - Grupos "Micose FUNGÓIDE/SÍNDROME DE SÉZARY” versus "CONTROLE": médias e desvios-padrão das variáveis e significância do teste estatístico aplicado

\begin{tabular}{|c|c|c|c|c|c|}
\hline & $N$ & MF/SS & $N$ & CONTROLE & $p$ \\
\hline LEUCÓCITOS(*) & 15 & $17614,67 \pm 22228,31$ & 25 & $6200,00 \pm 1557,50$ & 0,009 \\
\hline LINFÓCITOS(*) & 15 & $9504,07 \pm 19774,48$ & 25 & $1606,00 \pm 515,18$ & 0,016 \\
\hline EOSINÓFILOS(*) & 15 & $897,07 \pm 1072,50$ & 25 & $180,97 \pm 182,54$ & 0,041 \\
\hline$\% \mathrm{CS}$ & 14 & $7,50 \pm 12,98$ & - & - & - \\
\hline \%LP & 14 & $20,57 \pm 22,10$ & - & - & - \\
\hline CD3 TOTAL & 15 & $80,47 \pm 13,68$ & 25 & $72,90 \pm 6,45$ & 0,062 \\
\hline CD3/CD2 & 15 & $75,80 \pm 14,31$ & 25 & $68,26 \pm 6,73$ & 0,071 \\
\hline CD3/CD5 & 15 & $77,20 \pm 13,42$ & 25 & $67,34 \pm 8,77$ & 0,008 \\
\hline $\mathrm{CD} 3 / \mathrm{TCR} \alpha \beta\left(^{*}\right)$ & 15 & $76,00 \pm 14,33$ & 25 & $65,34 \pm 6,20$ & 0,009 \\
\hline $\mathrm{CD} 3 / \mathrm{CD} 7$ & 15 & $48,47 \pm 26,60$ & 25 & $58,84 \pm 8,62$ & 0,163 \\
\hline $\mathrm{CD} 3 / \mathrm{CD} 4$ & 15 & $58,77 \pm 19,57$ & 25 & $45,82 \pm 7,27$ & 0,025 \\
\hline RELAÇÃO CD4:CD8(*) & 16 & $9,36 \pm 14,23$ & 25 & $2,05 \pm 0,83$ & 0,026 \\
\hline $\mathrm{CD} 3 / \mathrm{CLA}\left({ }^{*}\right)$ & 13 & $8,31 \pm 9,09$ & 25 & $4,08 \pm 2,86$ & 0,349 \\
\hline $\mathrm{CD} 3 / \mathrm{CD} 25\left(^{*}\right)$ & 15 & $22,23 \pm 13,50$ & 25 & $9,70 \pm 5,87$ & 0,002 \\
\hline
\end{tabular}

$\mathrm{N}=$ número de exames computados na análise estatística para cada variável

$\left({ }^{*}\right)$ Váriáveis com suposição de normalidade não satisfeita analisadas por testes não paramétricos (Teste da mediana e Teste de Mann-Whitney) 
ANEXO 14 - Valores de referência para contagens linfocitárias e morfologia dos linfócitos no sangue periférico para o grupo controle sem doença cutânea ou doença linfoproliferativa conforme Oliveira, 2005

\begin{tabular}{|l|c|}
\hline \multicolumn{1}{|c|}{ Variável } & Valores de referência \\
\hline Linfócitos (células $/ \mathrm{mm}^{3}$ ) & $691-2722$ \\
\hline Número absoluto de CS (células $/ \mathrm{mm}^{3}$ ) & $<1000$ \\
\hline Células de Sézary (CS) / 100 linfócitos & $0-7$ \\
\hline Células de Sézary grandes / 100 linfócitos & 0 \\
\hline Linfócitos pleomórficos / 100 linfócitos & $0-24$ \\
\hline
\end{tabular}


ANEXO 15 - Valores de referência para os marcadores imunofenotípicos dos linfócitos do sangue periférico analisados pela CMF para um grupo controle sem doença cutânea ou doença linfoproliferativa conforme Oliveira, 2005

\begin{tabular}{|c|c|c|}
\hline Variável & & Valores de referência \\
\hline$\% \mathrm{CD}^{+}$Total & (células T) & $60-86$ \\
\hline$\% \mathrm{CD}^{+} \mathrm{CD}^{+}$ & & $55-81,5$ \\
\hline$\% \mathrm{CD}^{+} \mathrm{CD}^{+}$ & & $57-81$ \\
\hline$\% \mathrm{CD}^{+}{ }^{T} \mathrm{TRa}^{+}$ & & $51-78$ \\
\hline$\% \mathrm{CD}^{+} \mathrm{CD}^{+}$ & & $31-60$ \\
\hline$\% \mathrm{CD}^{+} \mathrm{CD}^{+}$ & & $11-38$ \\
\hline Relação CD4:CD8 & & $0,4-3,6$ \\
\hline$\% \mathrm{CD}^{+} \mathrm{CD}^{+} \mathrm{CD}^{+}$ & & $0-2,4$ \\
\hline$\% \mathrm{CD}^{+} \mathrm{CD}^{+}$ & & $42-76$ \\
\hline$\% \mathrm{CD}^{+} \mathrm{CD}^{-}$ & & $3-32$ \\
\hline$\% \mathrm{CD}^{+} \mathrm{CLA}^{+}$ & & $0-7$ \\
\hline$\% \mathrm{CD}^{+} \mathrm{CD} 25^{+}$ & & $3-25$ \\
\hline$\% \mathrm{CD}^{+} \mathrm{CD} 69^{+}$ & & $0-10$ \\
\hline$\% \mathrm{CD}^{+}{ }^{\mathrm{TCR}} \delta^{+}$ & & $1-15$ \\
\hline$\% \mathrm{CD}^{-} \mathrm{CD} 16^{+} \mathrm{CD}^{2} 6^{+}$ & (células NK) & $1-22,5$ \\
\hline$\% \mathrm{CD}^{+} 9^{+}$ & (células B) & $2-19$ \\
\hline
\end{tabular}


8. REFERÊNCIAS 
Abrahams I, Mc Carthy JT, Sanders SL. One hundred and one cases of exfoliative dermatitis. Arch Dermatol. 1963;87:96-101.

Agarwal S, Khullar R, Kalla G, Malhotra YK. Nose sign of exfoliative dermatitis: a possible mechanism. Arch Dermatol. 1992;128:704.

Akhyani M, Ghodsi ZS, Toosi S, Dabbaghian H. Erythroderma: a clinical study of 97 cases. BMC Dermatol. 2005;5:5.

Bakels V, van Oostveen JW, Gordijn RLJ, Walboomars JM, Meijer CJ, Willemze R. Diagnostic value of T-cell receptor beta gene rearrangement analysis on 
peripheral blood lymphocytes of patients with erythroderma. $\mathrm{J}$ Invest Dermatol.1991;97:782-6.

Bang K, Lund M, Wu K, Mogensen SC, Thestrup-Pedersen K. CD4+ CD8+ (thymocyte-like) $\mathrm{T}$ lymphocytes present in blood and skin from patients with atopic dermatitis suggest immune dysregulation. $\mathrm{Br} \mathrm{J}$ Dermatol. 2001; 144:1140-7.

Bernengo MG, Quaglino P, Novelli M, Cappello N, Doveil GC, Lisa F, De Matteis A. Prognostic factors in Sézary syndrome: a multivariate analysis of clinical, haematological and immunological features. Ann Oncol. 1998;9:857-63.

Bernengo MG, Novelli M, Quaglino P, Lisa F, De Matteis A, Savoia P, Cappello $\mathrm{N}$. The relevance of the CD4+ CD26- subset in the identification of circulating Sézary cells. Br J Dermatol. 2001;144:125-35.

Botella-Estrada R, Sanmartin O, Oliver V, Febrer I, Aliaga A. Erythroderma: A clinicopathological study of 56 cases. Arch Dermatol. 1994;130:1503-7.

Bunn PA Jr, Lamberg SL. Report of the Committee on Staging and Classification of Cutaneous T-cell Lymphomas. Cancer Treat Rep. 1979; 63:725-8. 
Callot V, Roujeau JC, Bagot M, Wechsler J Chosidow O, Souteyrand P, Morel P, Dubertret L, Avril MF, Revuz J. Drug-induced pseudolymphoma and hypersensitivity syndrome. Two different clinical entities. Arch Dermatol. $1996 ; 132: 1315-21$.

Chu AC, Robinson D, Hawk JLM, Meachan R, Spittle MF, Smith NP. Immunologic differentiation of the Sézary syndrome due to cutaneous T-cell lymphoma and chronic actinic dermatitis. J Invest Dermatol. 1986;86:134-7.

Cordel N, Lenormand B, Courville P, Helot MF, Benichou J, Joly P and French Study Group on Cutaneous Lymphoma. Usefulness of cutaneous T-cell clonality analysis for the diagnosis of cutaneous T-cell lymphoma in patients with erythroderma. Arch Pathol Lab Med. 2005;129:372-6.

Delfau-Larue MH, Laroche L, Wechsler J, Lepage E, Lahet C, Asso-Bonnet M. Diagnostic value of dominant T-cell clones in peripheral blood in 363 patients presenting consecutively with a clinical suspicion of cutaneous lymphoma. Blood. 2000;96:2987-92.

D'Incan M, Souteyrand P, Bignon YJ, Fonck Y, Roger H. Hydantoin-induced cutaneous pseudolymphoma with clinical, pathologic, and immunologic aspects of Sézary syndrome. Arch Dermatol. 1992;128:1371-4. 
Diwan AH, Prieto VG, Herling M, Duvic M, Foss F. Primary Sézary syndrome commonly shows low-grade cytologic atypia and an absence of epidermotropism. Am J Clin Pathol. 2005;123:510-5.

Economidou J, Choreme H, Kofina A, Tosca A, Kotsakis P, Vareldzidis A, Stratigos J. Blood lymphocyte subpopulations studied with monoclonal antibodies in leukemic stages of mycosis fungoides. Dermatologica. 1985;170:59-64.

Edelson RL, Kirkpatrick CH, Shevach EM. Preferencial cutaneous infiltration by neoplastic thymus derived lymphocytes. Morphologic and functional studies. Ann Intern Med. 1974;80:685-92.

Flaxman BA, Zelany G, Van Scott EJ. Nonespecificity of characteristic cells in mycosis fungoides. Arch Derm 1971;104:141-7.

Foss FM. Interleukin-2 fusion toxin: targeted therapy for cutaneous T-cell lymphoma. Ann NY Acad Sci 2001;941:166-76.

Gentele H, Lodin A, Skog E: Dermatitis exfoliativa: Cases admitted in the decade 1948-1957 to the dermatological clinic, Karolinska Sjukhuset, Stockholm, Sweden. Acta Derm Venereol. 1958;38:296-301. 
Groves RW, Kapahi P, Barker JNWN, Haskard DO, Mac Donald DM. Detection of circulating adhesion molecules in erythrodermic skin disease. J Am Acad Dermatol. 1995;33:32-6.

Guccion JG, Fischman AB, Bunn PA Jr, Schechter GP, Patterson RH, Matthews MJ. Ultrastructural appearance of cutaneous T cell lymphomas in skin, lymph nodes, and peripheral blood. Cancer Treat Rep. 1979;63:565-70.

Harmon CB, Witzig TE, Katzmann JA, Pittelkow MR. Detection of circulating T cells with CD4+ CD7- immunophenotype in patients with benign and malignant Iymphoproliferative dermatoses. J Am Acad Dermatol. 1996;35:404-10.

Hasan T, Jansen CT. Erythroderma: A follow-up of fifty cases. J Am Acad Dermatol. 1983;8:836-40.

Haynes B, Bunn PA Jr, Mann D, Thomas C, Eisenbarth GS, Minna J, Fauci AS. Cell surface differentiation antigens of the malignant T cell in Sézary syndrome and mycosis fungoides. J Clin Invest. 1981;67:523-30.

Heald P, Yan SL, Edelson R. Profound deficiency in normal circulating T-cells in erythrodermic cutaneous T-cell lymphoma. Arch Dermatol. 1994;130:198-203. 
Iyer VK, Kopile K, Verma K. FNAC of dermathopatic lymphadenitis. Acta Cytol. 1998;42:1347-51.

Jakob T, Neuber K, Altenhoff J, Kowalzick L, Ring L. Stage-dependent expression of CD7, CD45RO, CD45RA and CD25 on CD-4 positive peripheral blood T-lymphocytes in cutaneous T-cell lymphoma. Acta Derm Venereol (Stockh). 1996;76:34-6.

Kamarashev J, Burg G, Kempf W, Hess Schmid M, Dummer R. Comparative analysis of histological and immunohistological features in mycosis fungoides and Sézary syndrome. J Cut Pathol.1998;25(8):407-12.

Karakayli G, Beckham G, Orengo I, Rosen T. Exfoliative dermatitis. Am Fam Physician.1999;59:625-30.

Kim Y, Bishop K, Varhese A, Hoppe RT. Prognostic factors in erythrodermic mycosis fungoides and Sezary syndrome. Arch Dermatol. 1995;131:1003-8.

King LE Jr, Dufrene RG, Lovett GL, Rosin MA. Erythroderma: review of 82 case. South Med J. 1986;79:1210-5.

Labastide W, Rana M, Baker C. A new monoclonal antibody (CH-F42) recognizes a CD7- subset of normal $T$ lymphocytes and circulating malignant 
cells in adult T-cell lymphoma-leukemia and Sézary syndrome. Blood. 1990;76:1361-8.

Laetsch B, Häffner AC, Döbbleling U, Seifert B, Ludwig E, Burg G, Dummer R. CD4+/CD7- $T$ cell frequency and polymerase chain reaction-based clonality assay correlate with stage in cutaneous T-cell lymphomas. J Invest Dermatol. 2000;114:107-11.

Leenutaphong V, Kulthanan K, Pohboon C, Suthipinittharn P, Sivayathorn A. Erythroderma in Thai patients. J Med Assoc Thai. 1999;82:743-8.

Levine N. Exfoliative dermatitis - skin biopsy required to determine the cause of this pruritic eruption. Geriatrics. 2000;55:25.

Leyva L, Torres MJ, Posadas S, Blanca M, BessoG, O’Valle F, del Moral RG. Anticonvulsivant induced toxic epidermal necrolysis: monitoring the immunologic response. J Allergy Clin Immunol. 2000;105:157-65.

Li LF, Sujan SA, Yang H, Wang WH. Serum immunoglobulins in psoriatic erythroderma. Clin Exper Dermatol. 2005;30:125-7.

Lima M, Almeida J, Teixeira MA, Queiros ML, Santos AM, Fonseca S, Balanzategui A, Justica B, Orfao A. Utility of flow cytometry immunophenotyping 
and DNA ploidy studies for diagnosis and characterization of blood involvement in CD4+ Sézary's syndrome. Haematologica. 2003;88:874-87.

Litovitz TL, Lutzner MA. Quantitative measurements of blood lymphocytes from patients with chronic lymphocytic leukemia and the Sézary syndrome. J Natl Cancer Inst. 1974;53:75-7.

Lutzner MA, Jordan HW. The ultrastructure of an abnormal cell in Sézary's syndrome. Blood. 1968;31:719-26.

Lutzner MA, Hobbs JW, Horvath P. Ultrastructure of abnormal cells in Sézary syndrome, mycosis fungoides, and parapsoriasis en plaque. Arch Dermatol. 1971;103:375-86.

Matutes E, Robinson D, O’Brien M, Haynes BF, Zola H, Catovsky D. Candidate counterparts of Sézary cells and adult T-cell lymphoma-leukemia cells in normal peripheral blood: an ultrastructural study with the immunogold method and monoclonal antibodies. Leuk Res. 1983;7:787-801.

Meijer CJLM, van Leewen AWFM, van der Loo EM, van der Putte LBA, van Vloten WA. Cerebriform (Sézary-like) mononuclear cells in healthy individuals: a morphologically distinct population of T-cells. Virchows Arch B cell Pathol. 1977;25:95-104. 
Miale JB. Laboratory medicine hematology. $5^{\mathrm{a}}$ ed. St Louis: The C.V. Mosby Company; 1978.

Montgomery $\mathrm{H}$. Exfoliative dermatosis and malignant erythroderma: the value and limitations of hystopathologic studies. Arch Dermatol Syph. 1933;27:253-73.

Morar N, Dlova N, Gupta AK, Naidoo DK, Aboobaker J, Randial PK. Erythroderma: a comparison between HIV positive and negative patients. Int J Dermatol. 1999;38:859-900.

Nicolis GD, Helwig EB. Exfoliative dermatitis: A clinicopathologic study of 135 cases. Arch Dermatol. 1973;108:788-97.

Oliveira PAF. Estudo do perfil morfológico e imunofenotípico dos linfócitos do sangue periférico de pacientes portadores de micose fungóide nas fases precoce e avançada [dissertação]. São Paulo: Faculdade de Medicina da Universidade de São Paulo; 2005.

Pal S, Haroon TS. Erythroderma: A clinico-etiologic study of 90 cases. Int J Dermatol. 1998;37:104-7.

Payne CM. Ultrastructural morphometry in the diagnosis of mycosis fungoides and Sézary's syndrome. Clin Dermatol. 1991;9:187-203. 
Paterson JW, Berry AD $3^{\text {rd }}$, Darwin Bs et al., Lichenoid histopathologyc changes in patients with clinical diagnosis of exfoliative dermatitis. Am J Dermatopathol. 1991;13:358-64.

Pavithran K. Nose sign of exfoliative dermatitis. Indian J Dermatol Venereol Leprol. 1988;52:42.

Reinhold U, Hepertz M, Kukel S, Oterman I, Uerlich M, Kreysel HW. Induction of nuclear contour irregularity during T-cell activation via the T-cell receptor/CD3 complex and CD2 antigens in the presence of phorbol esters. Blood. 1994;83:703-6.

Rosenthal CJ. Noguera CA, Coppola A, Kapelner SN. Pseudolymphoma with mycosis fungoides manifestations, hyporesponsiveness to diphenylhydantoin, and lymphocyte dysregulation. Cancer. 1982:49:2305-14.

Rothe MJ, Bialy TL, Grant-Kels JM. Erythroderma. Dermatol Clin. 2000; $18: 405-15$.

Rothe MJ, Bernstein ML, Grant-Kels JM. Life-threatening erythroderma: diagnosing and treating the "red man". Clin Dermatol. 2005;23:206-17. 
Rym BM, Mourad M, Bechir Z, Dalenda E, Faika C, ladh AM, Amel BO. Erythroderma in adults: a report of 80 cases. Int J Dermatol. 2005;44:731-5.

Sausville EA, Eddy JL, Makuch RW, Fischmann AB, Schechter GP, Matthews M, Glatstein E, Ihde DC, Kaye F, Veach SR. Histopathologic staging as initial diagnosis of mycosis fungoides and the Sezary syndrome: definition of three distinctive prognostic groups. Ann Intern Med. 1988;109:372-82.

Schechter GP, Sausville EA, Fischmann AB, Soehnlen F, Eddy J, Matthews M, Gazdar A, Guccion J, Makuch R. Evaluation of circulating malignant cells provides prognostic information in cutaneous $\mathrm{T}$ cell lymphoma. Blood. 1987;69:841-9.

Sehgal VN, Srivastava G: Exfoliative dermatitis: A prospective study of 80 patients. Dermatologica. 1986;173:278-84.

Sehgal VN, Srivastava G, Sardana K. Erythroderma / exfoliative dermatitis: a synopsis. Int J Dermatol. 2004;43:39-47.

Sentis HJ, Willemze R, Scheffer E. Histopathologic studies in Sézary syndrome and erythrodermic mycosis fungoides: a comparison with benign forms of erythroderma. J Am Acad Dermatol. 1986;15:1217-26. 
Sigurdsson V, Toonstra J, Hezemans-Boer M, Van Vloten DW. Erythroderma: A clinical and follow-up study of 102 patients, with special emphasis on survival. J Am Acad Dermatol. 1996;35:53-7.

Sigurdsson V, Toonstra J, Van Vloten WA. Idiopathic erythroderma: a follow-up study of 28 patients. Dermatology. 1997;194:98-101.

Sigurdsson V, Steegmans PH, Van Vloten WA. The incidence of erythroderma: a survey among all dermatologists in The Netherlands. J Am Acad Dermatol. 2001;45:675-8.

Stolz W, Schmoeckel C, Burg, Braun-Falco O. Circulating Sézary cells in the diagnosis of Sézary syndrome (quantitative and morphometric analysis). J Invest Derm. 1983;81:314-9.

Tancrede-Bohin E, Ionescu MA, de La Salmoniere P, Dpuy A, Rivet J, Rybojad M, Dubertret L, Bachelez H, Lebbe C, Morel P. Prognostic value of blood eosinophilia in primary cutaneous T-cell lymphomas. Arch Dermatol 2004;140:1057-61.

Thestrup-Pedersen K, Halkier-Sorensen L, Sogaard H, Zachariae H. The red man syndrome: Exfoliative dermatitis of unknown etiology: A description and follow-up of 38 patients. J Am Acad Dermatol. 1988;18:1307-12. 
Tomasini C, Aloi F, Solaroli C, Pippione M. Psoriatic erythroderma: A histopathologic study of forty-five patients. Dermatology. 1997;194:102-6.

Trotter MJ, Whittaker SJ, Orchard GE, Smith NP. Cutaneous histopathology of Sezary syndrome: a study of 41 cases with a proven circulating T-cell clone. $\mathrm{J}$ Cut Pathol. 1997;24:286-91.

Van Fletcher V, Zachheim HS, Beckstead JH. Circulating Sézary cells. A new preparatory method for their identification and enumeration. Arch Pathol Lab Med. 1984;108:954-8.

Vasconcelos C, Domingues P, Aoki V, Miyake RK, Sawaia N, Martins JEC. Erythroderma: analysis of 247 cases. Rev Saude Publica. 1995;29:177-82.

Veelken H, Wood GS, Sklar J. Molecular staging of cutaneous T cell lymphoma: evidence for systemic involvement in early disease. $\mathrm{J}$ Invest Dermatol. 1995;104:889-94.

Vonderheid EC, Sobel E, Nowell P, Finan JB, Helfrich MK, Whipple DS. Diagnostic and prognostic significance of Sezary cells in peripheral blood smears from patients with cutaneous T-cell lymphoma. Blood. 1985;66:358-66. 
Vonderheid EC, Bernengo MG, Burg G, DuvicM, Heald P, Laroche L, Olsen E, Pittelkow M, Russell-Jones R, Takigawa M, Willemze R, ISCL. Update on erythrodermic cutaneous T-cell lymphoma: report of the International Society for Cutaneous Lymphomas. J Am Acad Dermatol. 2002;46:95-106.

Vonderheid EC. On the diagnosis of erythrodermic cutaneous T-cell lymphoma. J Cutan Pathol. 2006;33(Suppl.1):27-42.

Walsh NM, Prokopetz R, Tron VA, Sawyer DM, Watters AK, Murria S, Zip C. Histopathology in erythroderma: review of a series of cases by multiple observers. J Cutan Pathol. 1994;21:419-23.

Washington LT, Huh YO, Powers LC, Duvic M, Jones D. A stable aberrant immunophenotype characterizes nearly all cases of cutaneous T-cell lymphoma in blood and can be used to monitor response to therapy. BMC Clin Pathol. 2002;2:5.

Whittaker SJ, Smith NP, Jones RR, Luzzatto L. Analysis of beta, gamma and delta receptor genes in mycosis fungoides and Sézary syndrome. Cancer. 1991;68:1572-82.

Willenze R, van Vloten WA, Hermans J, Damsteeg MJM, Meijer CJLM. Diagnostic criteria in Sezary's syndrome: a multiple parameter study of 
peripheral blood lymphocytes in 32 patients with erythroderma. $\mathrm{J}$ Invest Dermatol. 1983;81:392-7.

Willenze R, Damsteeg WJ, Meijer CJ. Distribution of T-cell subpopulation in the peripheral blood of patients with erythrodermic psoriasis. Arch Dermatol Res. $1985 ; 277: 19-23$.

Willenze R, Jaffe ES, Burg G, Cerroni L, Berti E, Swerdlow SH, Ralfkiaer E, Chimenti S, Diaz-Perez JL, Duncan LM, Grange F, Harris NL, Kempf W, Kerl H, Kurser M, Knobler R, Pimpinelli N, Sander C, Santucci M, Sterry W, Vermeer $\mathrm{MH}$, Wechsler J, Whittaker S, Meijer CJ. WHO-EORTC classification for cutaneous lymphomas. Blood. 2005;105:3768-84.

Wilson HTH. Exfoliative dermatitis: its etiology and prognosis. Arch Dermatol. 1954;69:577-81.

Winkelman RK, Linman JW. Erythroderma with atypical lymphocytes (Sézary syndrome). Am J Med. 1973;55:192-8.

Winkelman RK. Clinical studies of T-cell erythroderma in the Sézary syndrome. Mayo Clin Proc. 1974;49:519-25. 
Winkelman R, Hoaglang $\mathrm{H}$. The Sézary cell in the blood of patients with mycosis fungoides. Dermatologica. 1980;160:73-9.

Winkelman RK, Peters MS. Absolute number of circulating Sézary cells (letter). Arch Dermatol. 1981;117:382.

Wood GS, Abel EA, Hope RT. Leu-8 and Leu-9 antigen phenotypes: immunologic criteria for the distinction of mycosis fungoides and cutaneous inflammation. J Am Acad Dermatol. 1990;14:1006-13.

Zipp C, Murray S, Walsh NMG. The specificity of histopathology in erythroderma. J Cutan Pathol. 1993;20:393-8. 